\title{
Solubility Classification of Airborne Uranium Products from LWR-Fuel Plants
}

Prepared by D. R. Kalkwarf

Pacific Northwest Laboratory

Operated by

Battelle Memorial Institute

Prepared for

U.S. Nuclear Regulatory

Commission 


\section{NOTICE}

This report was prepared as an account of work sponsored by an agency of the United States Government. Nienther ine United States Government nor any agency thereof. or any of their employees, makes any warranty, expressed or irmplied, or assumes any legai liability or responsibility for any inird party's use, or the results of such use, of any int, rmation. apparatus product or process disclosed in this report, or represents that its use by such third party would not tifinge privately owned rights.

Available from

GPO Sales Program

Division of Technical Information and Document Control

U. S. Nuclear Regulatory Commission 'ashington, D. C. 20555

Printed copy price: $\$ 3.75$

and

National Technical Information Service Soringfield, Virginia 22161 
- Solubility Classification of Airborne Uranium Products from LWR-Fuel Plants

Manuscript Completed: July 1980

Date Published: August 1980

Prepared by

D. R. Kalkwarf

Pacific Northwest Laboratory

Richland, WA 99352

\section{Prepared for}

Division of Siting. Health and Safeguards Standards

Office of Standards Development

U.S. Nuclear Regulatory Commission

Washington, D.C. 20555

NRC FIN No. B21239 


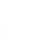

. 


\section{ABSTRACT}

Airborne dust samples were obtained from various locations within plants manufacturing fuel elements for light-water reactors, and the dissolution rates of uranium from these samples into simulated lung fluid at $37^{\circ} \mathrm{C}$ were measured. These measurements were used to classify the solubilities of the samples in terms of the lung clearance model proposed by the International Commission on Radiological Protection. Similar evaluations were performed for samples of pure uranium compounds expected as components in plant dust. The variation in solubility classifications of dust encountered along the fuel production lines is described and correlated with the process chemistry and the solubility classifications of the pure uranium compounds. 


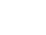

. 


\section{SOLUBILITY CLASSIFICATION OF AIRBORNE URANIUM PRODUCTS}

FROM LWR-FUEL PLANTS

\section{EXECUTIVE SUMMARY}

Airborne uranium dust samples were obtained from several locations within each of four plants manufacturing fuel elements for light-water reactors, and the dissolution rates of these mixtures and their pure components were classified in terms of the ICRP Task Group Lung Mode]. Each sample was exposed to well-agitated quantities of simulated iung fluid at $37^{\circ} \mathrm{C}$, and classification was based on the fraction, $F$, of uranium remaining undissolved as a function of time. In order to allow for the presence of more than one type of uranium compound in a sample, this functional dependence was represented by a sum of exponential terms, i.e., $F=\sum_{i} f_{j} \exp \left(-0.693 t / T_{i}\right)$, where $f_{j}$ is the initial weight fraction of component $i$ and $T_{j}$ is $i$ ts dissolution half-time. Based on such measurements, the following classifications are recommended for pure uranium compounds expected as dust components in the plants: $\left(\mathrm{NH}_{4}\right)_{2} \mathrm{U}_{2} \mathrm{O}_{7}-\mathrm{D}$; $\mathrm{UO}_{3}-48 \%, 52 \% \mathrm{Y}$; $\mathrm{UF}_{4}-\mathrm{Y} ; \mathrm{U}_{3} \mathrm{O}_{8}-\mathrm{Y}$; and $\mathrm{UO}_{2}-\mathrm{Y}$. The dissolution-rate classifications of plant dust generally were in agreement with expectations based on process chemistry at a sample-collection site and the classifications of the pure compounds expected at that site. They varied with distance along the processing lines from largely $D$ at the $U F_{6}$ vaporizers to entirely $Y$ where the finished pellets are ground to size. Dissolution of the uranium-bearing components was shown to be the result of reaction with bicarbonate ion to form the soluble $\left[\mathrm{UO}_{2}\left(\mathrm{CO}_{3}\right)_{3}\right]^{4-}$ anion. 



\section{TABLE OF CONTENTS}

ABSTRACT .........................

EXECUTIVE SUMMARY. ..................

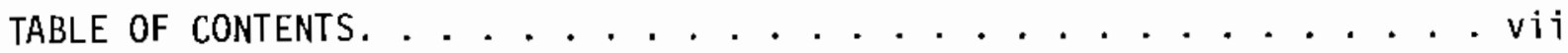
FIGURES. .................... . .

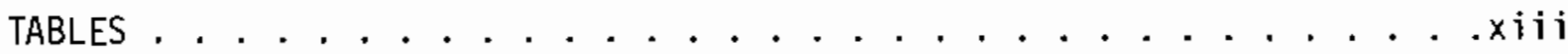

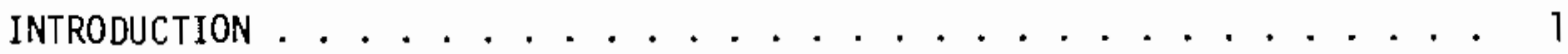

CONCLUSIONS AND RECOMMENOATIONS. ............... 3 PROCEOURE. .......................... 5

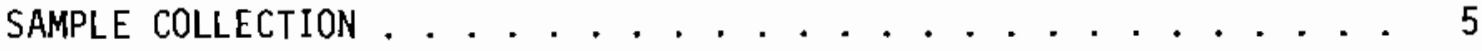

SAMPLE PREPARATION AND CHARACTERIZATION .......... 5

PREPARATION OF SIMULATEO LUNG FLUID . . . . . . . . . . . . . 6

DISSOLUTION TECHNIQUES. . . . . . . . . . . . . . . 7

URANIUM ANALYSIS. ................... 10

EVALUATION OF DISSOLUTION HALF-TIMES. ............ 16

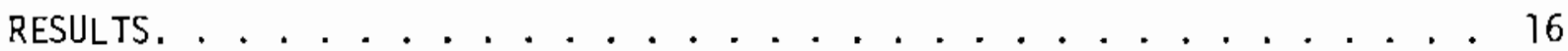

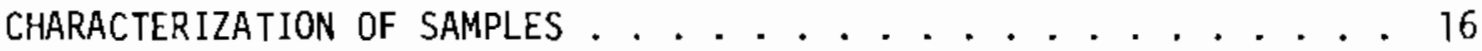

DISSOLUTION BEHAVIOR OF SAMPLES .................. 18

SOLUBILITY CLASSIFICATIONS OF SAMPLES ............ 5 I

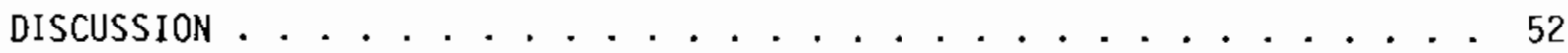

COMPARISON OF CLASSIFICATIONS WITH LITERATURE VALUES. . . . . . 53

COMPARISON OF PLANT-SAMPLE CLASSIFICATIONS WITH EXPECTATIONS. . . . 54

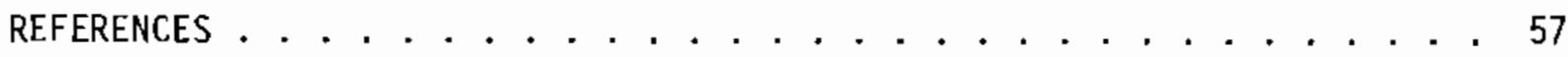

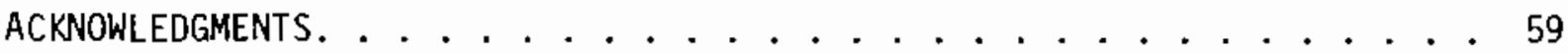




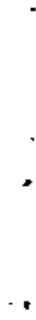




\section{FIGURES}

1. Schematic Production Lines for LWR-Fuel Rods. . . . . . . . . . . . 4

2. Sample Container for Dissolution by the Sandwich Technique. . . . . . 9

3. Sample Container for Dissolution by the Mini-Batch Technique. . . . . Il

4. Calibration Curve for Uranium Assay in Simulated Lung Fluid . . . . . I2

5. Calibration Curve for Uranium Assay in Oxidized Simulated Lung Fluid at $425 \mathrm{~nm}$. . . . . . . . . . . . . . . . . . 14

6. Calibration Curve for Uranium Assay as the Dibenzoylmethane Complex at $415 \mathrm{~nm}$....................... 15

7. Dissolution of Uranium Dioxide Dust, Obtained from the New Brunswick Laboratory, into Simulated Lung Fluid at $37^{\circ} \mathrm{C}$. . . . . . 19

8. Dissolution of Uranium Octoxide Dust, Obtained from the New Brunswick Laboratory, into Simulated Lung Fluid at $37^{\circ} \mathrm{C}$. . . . . 20

9. Dissolution of Uranium Trioxide Dust Obtained from the New Brunswick Laboratory into Simulated Lung Fluid at $37^{\circ} \mathrm{C}$. . . . . . . 21

10. Dissolution of Uranium Tetrafluoride Dust Obtained from the New Brunswick Laboratory into Simulated Lung Fluid at $37^{\circ} \mathrm{C}$. . . . . 22

11. Dissolution of Ammonium Diuranate Dust Obtained from the Westinghouse Corporation into Simulated Lung Fluid at $37^{\circ} \mathrm{C}$. . . . . 23

12. Dissolution of Dust Collected at Exxon's ADU Granulator Discharge into Simulated Lung Fluid at $37^{\circ} \mathrm{C}$. . . . . . . . . . . 24

33. Dissolution of Oust Collected at Exxon's ADU Calciner Discharge into Simulated Lung Fluid at $37^{\circ} \mathrm{C}$. . . . . . . . . 25

14. Oissolution of Dust Collected at Exxon's Pellet Grinder into Simulated Lung Fluid at $37^{\circ} \mathrm{C}$. . . . . . . . . . . . . 26

15. Dissolution of Oust Collected at Exxon's Scrap Recovery Area, into Simulated Lung Fluid at $37^{\circ} \mathrm{C}$. . . . . . . . . . . . 27

16. Dissolution of Dust, Collected at Babcock \& Wilcox's $\mathrm{JF}_{6}$ Hydrolyzer, into Simulated Lung Fluid at $37^{\circ} \mathrm{C} . . . . . . .28$

17. Dissolution of Dust, Collected at Babcock \& Wilcox's ADU Granulator Discharge, into Simulated Lung Fluid at $37^{\circ} \mathrm{C}$. . . . . 29

18. Dissolution of Dust, Collected at Babcock \& Wilcox's ADU Calciner Discharge, into Simulated Lung Fluid at $37^{\circ} \mathrm{C} . . . . .30$

19. Dissolution of Dust, Collected at Babcock \& Wilcox's Reduction Kiln Discharge, into Simulated Lung Fluid at $37^{\circ} \mathrm{C} . . . . . . . .3$ ? 
FIGURES (cont'd)

20. Dissolution of Dust, Collected at Babcock \& Wilcox's

Pellet Grinders, into Simulated Lung Fluid at $37^{\circ} \mathrm{C} \ldots . . . .32$

21. Dissolution of Dust Collected at Babcock \& Wilcox's

Uranium Scrap Recovery Area, into Simulated Lung

Fluid at $37^{\circ} \mathrm{C}$

22. Dissolution of Dust Collected at Babcock \& Wilcox's Uranium Scrap Dissolver, into Simulated Lung Fluid at $37^{\circ} \mathrm{C} \ldots \ldots . \ldots 34$

23. Dissolution of Dust Collected at Westinghouse's ADU

Granulator Discharge, into Simulated Lung Fluid at $37^{\circ} \mathrm{C} \ldots . .35$

24. Dissolution of Dust Collected at Westinghouse's Sintering

Furnace Feed, into Simulated Lung Fluid at $37^{\circ} \mathrm{C} \ldots \ldots 36$

25. Dissolution of Dust Collected at Westinghouse's Uranium Scrap Recovery Area, into Simulated Lung Fluid at $37^{\circ} \mathrm{C}$. . . . 37

26. Dissolution of Dust Collected at General Electric's $\mathrm{UF}_{6}$ Vaporization Room, into Simulated Lung Fluid at $37^{\circ} \mathrm{C}$. . . . . . 38

27. Dissolution of Dust, Collected at General Electric's UF 6 Hydrolyzer, into Simulated Lung Fluid at $37^{\circ} \mathrm{C}$. . . . . . . . 39

28. Dissolution of Dust, Collected at General Electric's ADU Calciner Feed, into simulated Lung Fluid at $37^{\circ} \mathrm{C}$. . . . . . . 40

29. Dissolution of Dust, Collected at Genera] Electric's GECO Calciner Feed, into Simulated Lung Fluid at $37^{\circ} \mathrm{C}$. . . . . . 41

30. Dissolution of Dust Collected at General Electric's ADU Calciner Discharge, into Simulated Lung Fluid at $37^{\circ} \mathrm{C} \ldots 42$

31. Dissolution of Dust Collected at General Electric's GECO Calciner Discharge, into Simulated Lung Fluid at $37^{\circ} \mathrm{C} . . . .43$

32. Dissolution of Dust Collected at General Electric's Pellet Press, into Simulated Lung Fluid at $37^{\circ} \mathrm{C}$......... . 44

33. Dissolution of Dust Collected at General Electric's Pellet Grinder, into Simulated Lung Fluid at $37^{\circ} \mathrm{C} \ldots . . . . .45$

34. Dissolution of Dust Collected at General Electric's Chem Room Air Recirculation Intake, ADU End, into Simulated

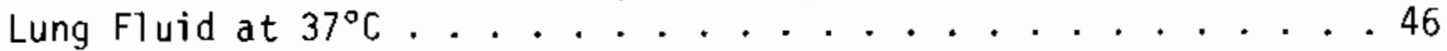




\section{FIGURES (cont'd)}

35. Dissolution of Dust Collected at General Electric's Chem Room Air Recirculation Intake, Center, into Simulated

Lung Fluid at $37^{\circ} \mathrm{C} \ldots \ldots . \ldots 47$

36. Dissolution of Dust Collected at General Electric's Chem Room Air Recirculation Intake, GECO End, into Simulated Lung Fluid at $37^{\circ} \mathrm{C} \ldots \ldots . . . . . . . . . .48$

37. Optical Absorption Spectrum of $1.78 \mathrm{~g} / \ell$ Uranium Solution in Simulated Lung Fluid ............... . . 49 


\section{$\underline{\text { TABLES }}$}

1. Compositions of Actual and Simulated Lung Fluids . . . . . . . . 7

2. Description of Samples................... 17

3. Microprobe and X-ray Crystallographic Analyses of Individual Particles . . . . . . . . . . . . . 18

4. Weight Fractions and Dissolution Half-Times of Uranium Components . . . . . . . . . . . . . . . . . . . . . 50

5. 0issolution-rate Classifications of Samples in Terms of the ICRP Task Group Lung Model .. . . . . . . . . . . . . 5 ? 


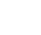

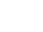




\section{INTRODUCTION}

The purpose of this study was to obtain airborne dust samples at various locations within plants manufacturing fuel elements for light-water reactors (LWR), and to classify the uranium-dissolution rates of these samples in terms of the ICRP Task Group Lung Mode $1 .{ }^{1}$ The International Commission on Radiological Protection developed this model for use in computing the radiation dose from radionuclides deposited in the 1 ung. A key parameter is the classification of the deposited material according to the rate at which it leaves the lung. Three classes were established: $D, W$, and $Y$, corresponding to half-times in the lung of 0 to 10 days, 11 to 100 days, and $>100$ days, respectively. If clearance of the material from the lung is not strictly exponential with time, it is approximated by a sum of exponentials; and the material is classified according to the fractions of $D, W$, and $Y$ components. In the absence of biological data, lung-clearance half-times for materials have been approximated by their dissolution half-times in simulated lung fluids. ${ }^{1,}{ }^{3}$ Although endocytos is and ciliarymucus transport are known to contribute to lung clearance, experiments have indicated that a few days after dust deposition, dissolution determines the clearance rate for the lower respiratory tract. ${ }^{4,5}$ Given the lung-clearance classification for a material, its transport rates between other anatomical compartments are automatically assigned in the model. From these parameters, one can compute the residence times of the material and the associated radiation dose in each compartment. ${ }^{6}$

In the present study, uranium-bearing dust samples were obtained from four plants manufacturing LWR fuel elements. These plants were:

Babcock and Wilcox Co., Nuclear Materials Division, Apol 10, PA 15613

Exxon Nuclear Co., Richland, WA 99352

General Electric Co., Nuclear Energy Products Division, Wilmington, NC 28401

Westinghouse Corp., Nuclear Fuel Division, Columbia, SC 29205 
All four plants prepare fuel pellets by means of the ADU process, i.e., the conversion of uranium hexafluoride to ammonium diuranate (ADU) followed by its conversion to sintered uranium dioxide in pellet form according to the following steps:

Steps

1. $\mathrm{UF}_{6} \stackrel{\mathrm{H}_{2} \mathrm{O}}{\longrightarrow} \mathrm{UD}_{2} \mathrm{~F}_{2}$

2. $\mathrm{UO}_{2} \mathrm{~F}_{2} \stackrel{\mathrm{iNH}_{3}}{\longrightarrow}-\left(\mathrm{NH}_{4}\right)_{2} \mathrm{U}_{2} \mathrm{O}_{7}$

3. $\left(\mathrm{NH}_{4}\right)_{2} \mathrm{U}_{2} \mathrm{O}_{7} \stackrel{\text { heat }}{\longrightarrow}\left(\mathrm{NH}_{4}\right)_{2} \mathrm{U}_{2} \mathrm{O}_{7}+\mathrm{UO}_{3}$

4. $\left(\mathrm{NH}_{4}\right)_{2} \mathrm{U}_{2} \mathrm{O}_{7}, \mathrm{UO}_{3} \stackrel{\text { heat }}{\longrightarrow}-\mathrm{U}_{3} \mathrm{O}_{3}$

5. $\mathrm{U}_{3} \mathrm{O}_{8} \stackrel{\mathrm{H}_{2}}{\longrightarrow}-\mathrm{UO}_{2}$ (unsintered)

6. $\mathrm{UO}_{2}$ (unsintered) pressure $-\mathrm{UO}_{2}$ (unsintered)

7. $\mathrm{UO}_{2}$ (unsintered) heat $-\mathrm{UO}_{2}$ (sintered)

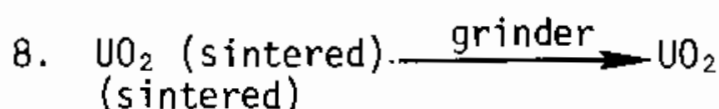

Plant Area

$U_{6}$ hydrolyzer

ADU precipitator

ADU granulator

ADU calciner

Reduction kiln

Pellet press

Sintering furnace

Pellet grinder

Any uranium scrap produced in the above steps is reprocessed as follows:
8. $U \operatorname{scrap} \stackrel{\text { heat }}{\longrightarrow} \mathrm{U}_{3} \mathrm{O}_{8}$
Scrap furnace
9. $\mathrm{U}_{3} \mathrm{O}_{8} \cdot \mathrm{HNO}_{3}-\mathrm{UO}_{2}\left(\mathrm{NO}_{3}\right)_{2}$
Scrap dissolver

The General Electric Co. also produces fuel pellets in its plant by a "dry process," termed the GECO process. Here, the first four steps of the ADU process are replaced by the following two steps:

Step

1. $\mathrm{UF}_{6} \stackrel{\text { dry steam }}{\longrightarrow} \mathrm{UO}_{2} \mathrm{~F}_{2}+\mathrm{U}_{3} \mathrm{O}_{8}+\mathrm{UF}_{4} \quad \mathrm{GECO} \mathrm{UF}_{6}$ converter

2. $\mathrm{UO}_{2} \mathrm{~F}_{2}, \mathrm{U}_{3} \mathrm{O}_{8}, \mathrm{UF}_{4} \stackrel{\mathrm{H}_{2}}{\longrightarrow} \mathrm{UO}_{2}$ (unsintered) GECO calciner

Since airborne dust formed in one area of a plant may be carried by convection or diffusion to other areas, it is important to consider the relative locations of the production equipment within a plant building. 
Generally, several production lines are located in parallel, running from one end of the building to the other as shown schematically in Figure 1 . It was expected that at least some of the dust samples would contain material from more than one source. For this reason, pure samples of $\mathrm{UO}_{2}, \mathrm{U}_{3} \mathrm{O}_{8}, \mathrm{UO}_{3}$, $\mathrm{UF}_{4}$, and $\left(\mathrm{NH}_{4}\right)_{2} \mathrm{U}_{2} \mathrm{O}_{7}$ were obtained and used for comparative dissolution measurements.

Dissolution-rate classifications were based on measurements of the fraction of uranium remaining undissolved in a sample as a function of time in simulated lung fluid at $37^{\circ} \mathrm{C}$. Maximum dissolution rates were sought by means of rapid agitation of the samples because the lung is expected to be a site for efficient dissolution and because the values were to approximate clearance rates that include contributions from endocytosis and ciliarymucus transport.

\section{CONCLUSIONS AND RECOMMENDATIONS}

Measurements of the fraction, $F$, of uranium remaining undissolved in a sample as a function of time in simulated lung fluid at $37^{\circ} \mathrm{C}$ and expression of these data as a sum of exponential terms, $F=\sum_{j} f_{j} \exp \left(-0.693 \mathrm{t} / \mathrm{T}_{j}\right)$, provided a practical basis for classifying the sample's dissolution rate in terms of the ICRP Task Group Lung Model. In such an expression, $f_{i}$ is the initial weight fraction of uranium component $i$ with dissolution half-time $T_{j}$. Based on such measurements, the following classifications are recommended for pure uranium compounds expected as dust components in LWR-fuel plants: $\quad\left(\mathrm{NH}_{4}\right)_{2} \mathrm{U}_{2} \mathrm{O}_{7}-\mathrm{D}$; $\mathrm{UO}_{3}-48 \% \mathrm{D}, 52 \% \mathrm{Y} ; \mathrm{UF}_{4}-\mathrm{Y} ; \mathrm{U}_{3} \mathrm{O}_{6}-\mathrm{Y}$; and $\mathrm{UO}_{2}$ - $Y$. The dissolution-rate classifications of the plant samples generally were in agreement with expectations based on process chemistry at a sample-collection site, the classifications for pure compounds 1 isted above, and the generally accepted $\mathrm{D}$ classification for $\mathrm{UF}_{6}, \mathrm{UO}_{2} \mathrm{~F}_{2}$, and $\mathrm{UO}_{2}\left(\mathrm{NO}_{3}\right)_{2}$.

At the front end of the ADU and dry processes, the dust was found to be largely (46 to $96 \%$ ) class $D$ in uranium with some $W$ and $Y$ components depending upon the particular sampling location. One of three samples showed a large amount of $Y$ component $(17 \% \mathrm{D}, 83 \% \mathrm{Y})$, and this unexpected result probably indicates that some air-sampling stations are exposed to unforeseen dust currents. At the ADU granulators and front ends of the ADU calciners, the dust was also found to be largely (45 to $72 \%$ ) class $D$, with 
FIGURE 1. Schematic Production Lines for LWR-Fuel Rods

ADU PROCESSES

ORY PROCESS
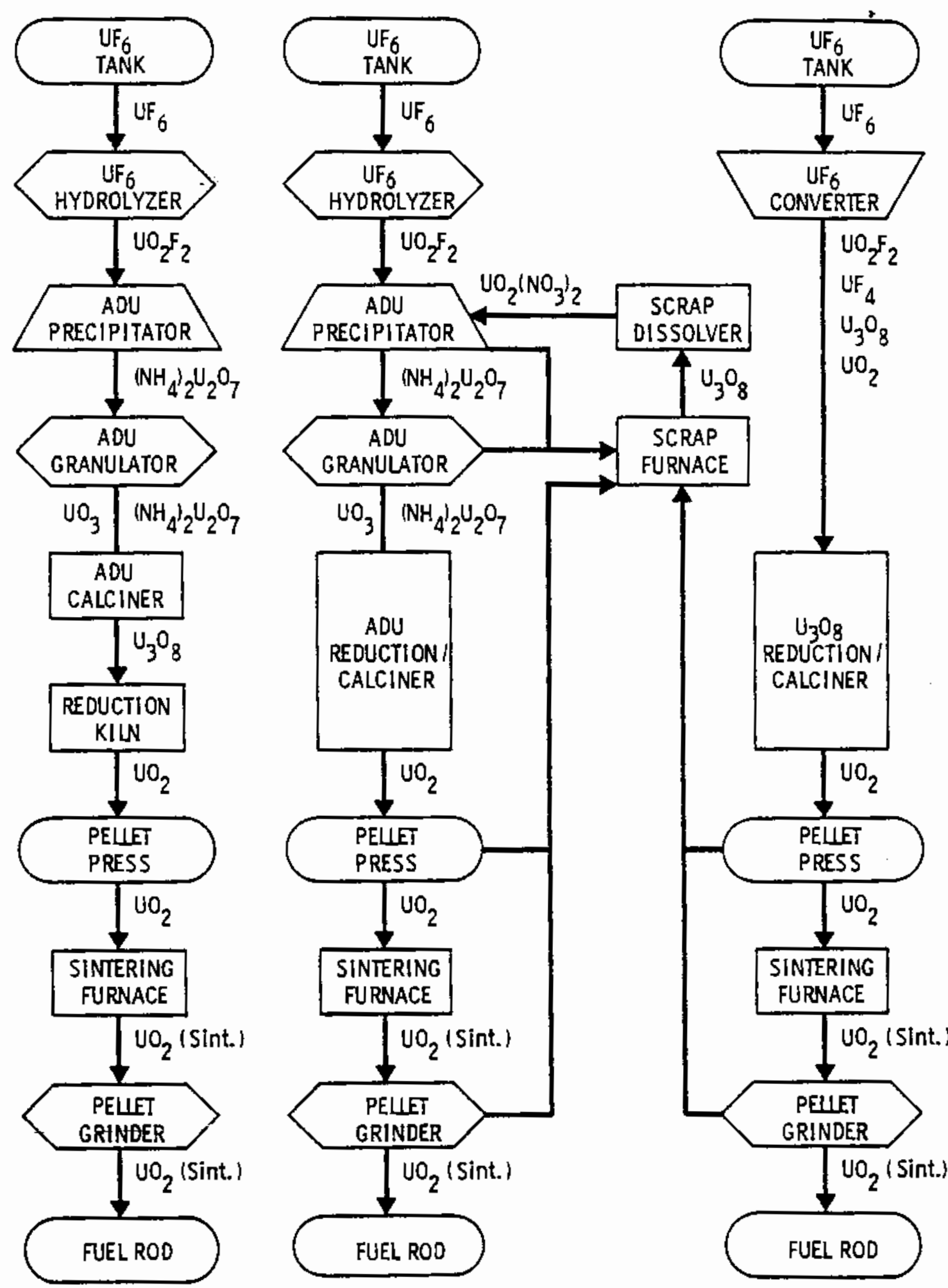
the remainder being class $Y$. At the front ends of the dry-process calciners, the dust was found to dissolve somewhat less rapidly, indicating a classification of $34 \% \mathrm{D}, 66 \% \mathrm{Y}$. From the discharge ends of the calciners to the grinders for the sintered fuel pellets, measurements showed that the dust should be classifjed 93 to $100 \%$ Y. The dissolution behavior of dust from the scrap-recovery areas indicated classifications ranging from $91 \% \mathrm{D}, 9 \% \mathrm{~W}$, to $100 \% \mathrm{Y}$, suggesting variable fractions of $\mathrm{UO}_{2}\left(\mathrm{NO}_{3}\right)_{2}$ and $\mathrm{U}_{3} \mathrm{O}_{3}$ in the samples. Thus, the dissolution-rate classification of uranium from dust varies substantially with location within a plant. The dissolution behavior of dust collected at the air-recirculation intakes for a room provides a composite classification of the dust generated therein, but individual workers in the room may be exposed to dust with a substantially different classification.

Concerning the mechanism of uranium dissolution in simulated lung fluid, it was concluded that uranium-bearing components in dust samples react with bicarbonate ion to form the soluble $\left[\mathrm{UO}_{2}\left(\mathrm{CO}_{3}\right)_{3}\right]^{4-}$ anion.

\section{PROCEDURE}

\section{SAMPLE COLLECTION}

Several dust samples were collected within each plant at locations determined by mutual consent of the staff health physicist and the author, following a tour of the facilities. The samples were collected by plant personnel close to the dust-generation sites within a given area. Generally, the samples were collected by drawing ambient air through cellulose or glassfiber filters; but in a few cases, the samples consisted of dust which settled on metal dishes placed in the area.

Pure samples of $\mathrm{UO}_{2}, \mathrm{U}_{3} \mathrm{O}_{3}, \mathrm{UO}_{3}$, and $\mathrm{UF}_{4}$ were obtained from the New Brunswick Laboratory of the U. S. Department of Energy, Argonne, Illinois. A pure sample of ammonium diuranate was obtained from the Westinghouse Corporation, Nuclear Fuel Division, Columbia, South Carolina.

SAMPLE PREPARATION AND CHARACTERIZATION

Samples received on filters were dried in a desicator over anhydrous calcium sulfate (J. T. Baker, Drierite) for two or three days, and then the 
dust was "vacuumed off" the surface with a vacuum line fitted with a 25-mm diameter membrane filter (Millipore, Type HA in a Swinnex holder). The dust collected on the membrane filter was transferred into a glass vial with a camel-hair brush. Settled dust samples were also dried before being stored in glass vials.

The plant samples were generally too small for measurements of their specific surface areas, and the particle-size ranges could only be estimated by microscopic sizing. The particle-size ranges of the pure reference compounds were adjusted to the range 0 to $45 \mu m$ by sieving.

Some of the individual dust particles were analyzed with a microprobe analyzer to determine their uranium content and with an X-ray diffraction camera to determine their crystallographic forms. Unfortunately, it was not possible to develop precise methods for assaying a dust sample with respect to component compounds and their crystallographic forms, within the scope of the present study.

\section{PREPARATION OF SIMULATED LUNG FLUID}

The electrolyte compositions of human interstitial lung fluid and the simulant used in this study are shown in Table 1. Comparison shows that they are almost identical. The protein components of actual lung fluid were represented by an ionically equivalent amount of citrate in the simulant as suggested by Moss. ${ }^{8}$ Lung-fluid proteins are poorly characterized and generally not available in large quantities, and substitute proteins hinder filtration and promote bacterial growth in solutions. Phospholipids, al so known to be present in trace amounts in actual lung fluid, were not included in the simulant for the same reasons. In a recent test, ${ }^{9}$ one of the suspected phospholipids, dipalmitoyl lecithin, was added to the simulant used in this experiment to form a $200 \mathrm{mg} / 2$ solution. No effect of this ingredient on the dissolution rate of uranium yellow cake samples was observed. 
TABLE 1. Compositions of Actual and Simulated Lung Fluids

\begin{tabular}{|c|c|c|}
\hline Ion & Actual ${ }^{7}$ & Simulated $^{8}$ \\
\hline $\begin{array}{l}\text { Calcium, } \mathrm{Ca}^{2+} \\
\text { Magnesium, } \mathrm{Mg}^{2+} \\
\text { Potassium, } \mathrm{K}^{+} \\
\text {Sodium, } \mathrm{Na}^{+}\end{array}$ & $\begin{array}{r}5.0 \mathrm{meq} / \mathrm{e} \\
2.0 \quad " 1 \\
4.0 \quad " 1 \\
145.0 \quad " \\
\end{array}$ & $\begin{array}{r}5.0 \mathrm{meq} / \mathrm{l} \\
2.0 \quad 11 \\
4.0 \quad " \\
145.0 \quad 1 \\
\end{array}$ \\
\hline Total Cations & 156.0 & 156.0 \\
\hline $\begin{array}{l}\text { Bicarbonate, } \mathrm{HCO}_{3}^{-} \\
\text {Chloride, } \mathrm{Cl}^{-} \\
\text {Citrate, } \mathrm{H}_{5} \mathrm{C}_{6} \mathrm{O}_{7}{ }^{3-} \\
\text { Acetate, } \mathrm{H}_{3} \mathrm{C}_{2} \mathrm{O}_{2}{ }^{-} \\
\text {Phosphate, } \mathrm{HPO}_{4}{ }^{2-} \\
\text { Sulfate, } \mathrm{SO}_{4}{ }^{2-} \\
\text { Protein }\end{array}$ & 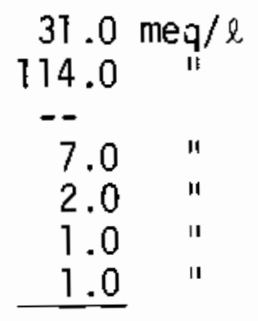 & 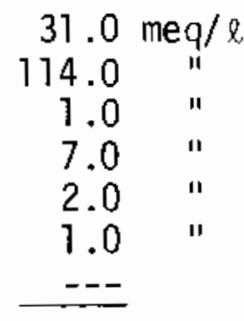 \\
\hline Total Anions & 156.0 & 156.0 \\
\hline $\mathrm{pH}$ & $7.3-7.4$ & $7.3-7.4$ \\
\hline
\end{tabular}

Simulated lung fluid with the composition shown in Table 1 was prepared by slowly adding the following ingredients in order to $990 \mathrm{ml}$ of distilled water and adjusting the final volume to $1000 \mathrm{ml}$ :

$$
\begin{aligned}
& 0.2033 \mathrm{~g} \mathrm{MgCl}_{2} \cdot 6 \mathrm{H}_{2} \mathrm{O} \\
& 6.0193 \mathrm{~g} \mathrm{NaCl} \\
& 0.2982 \mathrm{~g} \mathrm{KCl} \\
& 0.2680 \mathrm{~g} \mathrm{Na}_{2} \mathrm{HPO}_{4} \cdot 7 \mathrm{H}_{2} \mathrm{O} \\
& 0.0710 \mathrm{~g} \mathrm{Na}_{2} \mathrm{SO}_{4} \\
& 0.3676 \mathrm{~g} \mathrm{CaCl}_{2} \cdot 2 \mathrm{H}_{2} \mathrm{O} \\
& 0.9526 \mathrm{~g} \mathrm{NaH}_{3} \mathrm{C}_{2} \mathrm{O}_{2} \cdot 3 \mathrm{H}_{2} \mathrm{O} \\
& 2.6043 \mathrm{~g} \mathrm{NaHCO}_{3} \\
& 0.0970 \mathrm{~g} \mathrm{Na}_{3} \mathrm{H}_{3} \mathrm{C}_{6} \mathrm{O}_{7} \cdot 2 \mathrm{H}_{2} \mathrm{O}
\end{aligned}
$$

If the $\mathrm{pH}$ of the resulting solution was not $7.3-7.4$, it was adjusted to this value with small volumes of $1 \mathrm{~N} \mathrm{HCl}$.

DISSOLUTION TECHNIQUES

Dissolution trials on the uranium dust samples were conducted in well-agitated portions of simulated lung fluid (SLF) at $37^{\circ} \mathrm{C}$. Depending on the amount of sample available, one of three dissolution techniques was used. 
The "batch" technique described recently" was used when relatively large samples were available, such as those of the New Brunswick Laboratory reference compounds. A $0.6-\mathrm{g}$ dust sample was added to a 125-ml Erlenmeyer flask together with $100 \mathrm{ml}$ of SLF. The flask was then closed with a glass stopper and agitated in a shaker bath at $37 \pm 1^{\circ} \mathrm{C}$. After selected time periods, the flask was removed from the shaker, and the suspension was filtered through a membrane filter (Millipore, 45-mm diameter, HA, 0.45 um pore size). The filtrate was analyzed for uranium, and the undissolved dust was washed back into the Erlenmeyer flask with $100 \mathrm{ml}$ of fresh SLF. The flask was then replaced in the shaker bath for an additional time period. The pH of the suspension was checked every three days and adjusted to 7.3-7.4 with dilute hydrochloric acid, if necessary. At the end of 60 days, the undissolved residue in the flask was dissolved in $5.00 \mathrm{ml}$ of warm, concentrated nitric acid and analyzed for uranium.

A second dissolution technique, termed the "sandwich" technique, was designed for use with much smaller samples of uranium-bearing dust. A $0.05-g$ dust sample was sandwiched between two membrane filters (Millipore, 10-rm diameter, VF, $0.01 \mu m$ pore size) separated by a Teflon ring, 12.5-m 0.D., $8.5 \mathrm{~mm} \mathrm{I.D.} \mathrm{and} 0.85-\mathrm{mm}$ thick. Millipore Cement, Formulation No. 1, was used to bond the filters to the ring. Dissolution was started by dropping the sandwich into a 3-ml, conical-bottom vial (Pierce Chemical, Reacti-Vial) containing $3.00 \mathrm{ml}$ of SLF and a Teflon-coated, magnetic stirrer as shown in Figure 2. The vial was closed with a Teflon-lined screw cap and placed in a heating block/stirrer assembly (Pierce Chemical, Reacti-Therm Sys tenl) which drove the magnetic stirrer and kept the suspension within $37 \pm 1^{\circ} \mathrm{C}$. SLF permeated the sandwich and any soluble uranium rapidly diffused out into the well-stirred surrounding fluid. After selected time periods, the exposed SLF was removed from the vial for uranium analysis, and $3.00 \mathrm{ml}$ of fresh SLF was added to the vial to continue the dissolution. The $\mathrm{pH}$ of the suspension was checked every three days and adjusted to 7.3-7.4 with dilute hydrochloric acid, if necessary. After 60 days, the undissolved sample in the sandwich was dissolved in $3.00 \mathrm{ml}$ of warm concentrated nitric acid and analyzed for uranium. Although this technique was used successfully on the first few samples of fuel-plant dust, the sandwiches proved to be more fragile than 
FIGURE 2. Sample Container for Dissolution by the Sandwich Technique

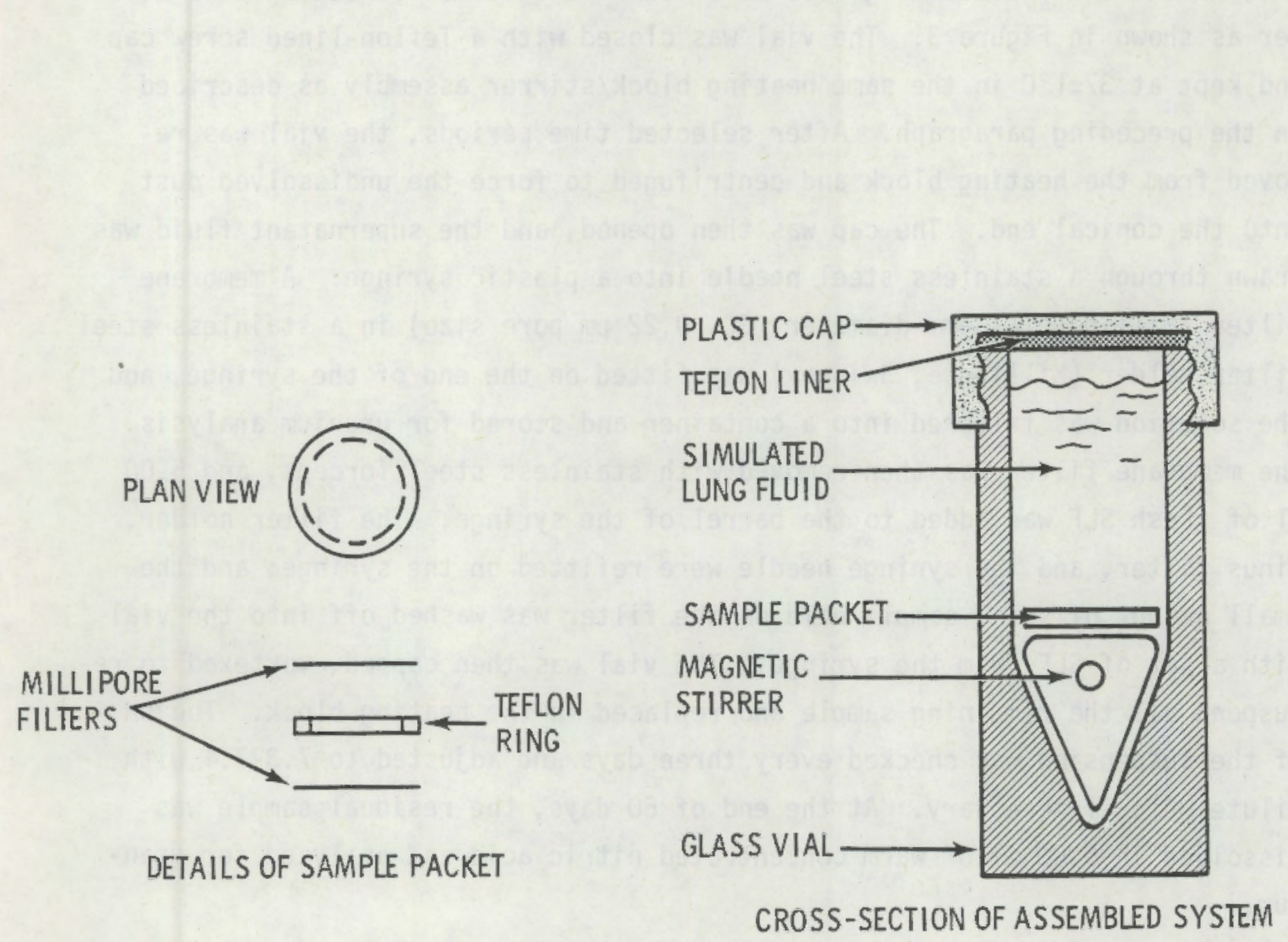


anticipated, requiring occasional repackaging of the sample. Thus, the technique described in the following paragraph was designed as an alternative.

A third dissolution technique, termed the "mini-batch" technique, was used with most of the samples of fuel-plant dust. Dissolution was started by adding a $0.05-\mathrm{g}$ dust sample to a $5-\mathrm{ml}$, conical-bottom vial (Pierce Chemical, Reacti-Vial) containing $5.00 \mathrm{ml}$ of SLF and a Teflon-lined magnetic stirrer as shown in Figure 3. The vial was closed with a Teflon-lined screw cap and kept at $37 \pm 1^{\circ} \mathrm{C}$ in the same heating block/stirrer assembly as described in the preceding paragraph. After selected time periods, the vial was removed from the heating block and centrifuged to force the undissolved dust into the conical end. The cap was then opened, and the supernatant fluid was drawn through a stainless steel needle into a plastic syringe. A membrane filter (Millipore, 13-rm diameter, GC, $0.22 \mu \mathrm{m}$ pore size) in a stainless steel filter holder (Millipore, Swinnex) was fitted on the end of the syringe, and the solution was filtered into a container and stored for uranium analysis. The membrane filter was then removed with stainless steel forceps, and 5.00 $\mathrm{ml}$ of fresh SLF was added to the barrel of the syringe. The filter holder, minus filter, and the syringe needle were refitted on the syringe; and the small amount of solid sample held on the filter was washed off into the vial with a jet of SLF from the syringe. The vial was then capped, vortexed to resuspend all the remaining sample and replaced in the heating block. The pH of the suspension was checked every three days and adjusted to 7.3-7.4 with dilute $\mathrm{HCl}$, if necessary. At the end of 60 days, the residual sample was dissolved in $5.00 \mathrm{ml}$ of warm concentrated nitric acid and analyzed for uranium.

URANIUM ANALYSIS

The filtrates obtained in dissolution trials using the batch technique were analyzed for uranium in one of two ways. If the dissolved uranium was known to be in the hexavalent state, the absorbance of the filtrate was measured directly in a 1-dm spectrophotometer cell at $448 \mathrm{~mm}$ versus a solution of uranium-free simulated lung fluid. The calibration curve for this assay method, using standard solutions of uranium, is shown in Figure 4. The concentration of uranium in a filtrate was obtained by dividing the measured absorbance by 1.005 , the absorptivity of the uranium in $\mathrm{lg}^{-1} \mathrm{dm}^{-1}$. If the 
FIGURE 3. Sample Container for Dissolution by the Mini-Batch Technique

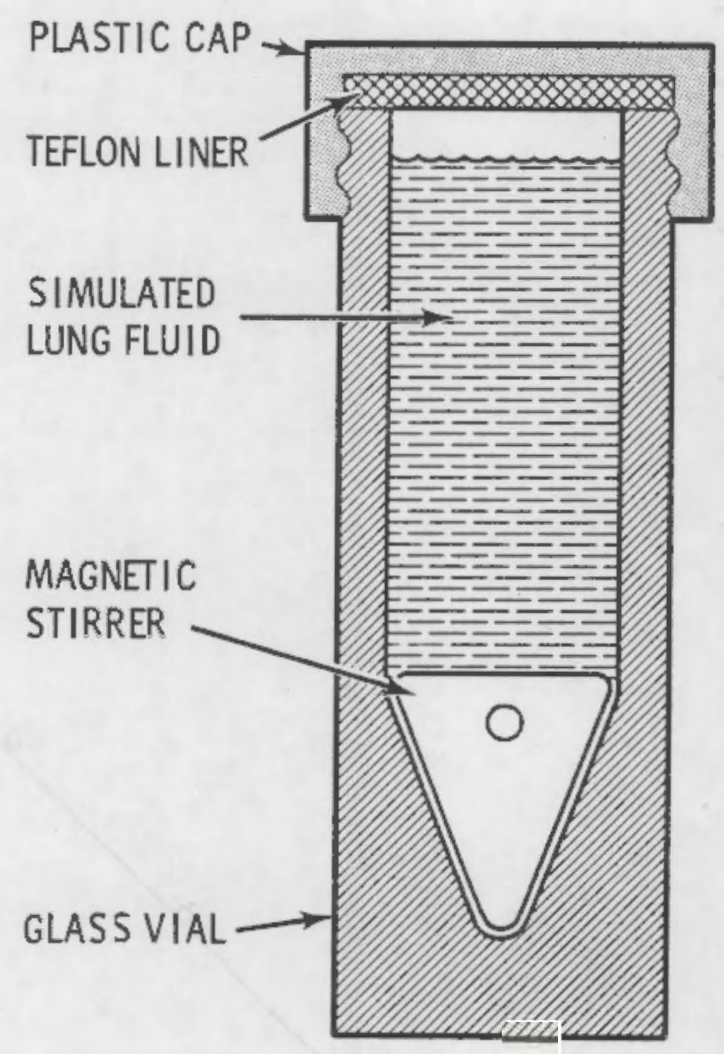


FIGURE 4. Calibration Curve for Uranium Assay in Simulated Lung Fluid at $448 \mathrm{~nm}$

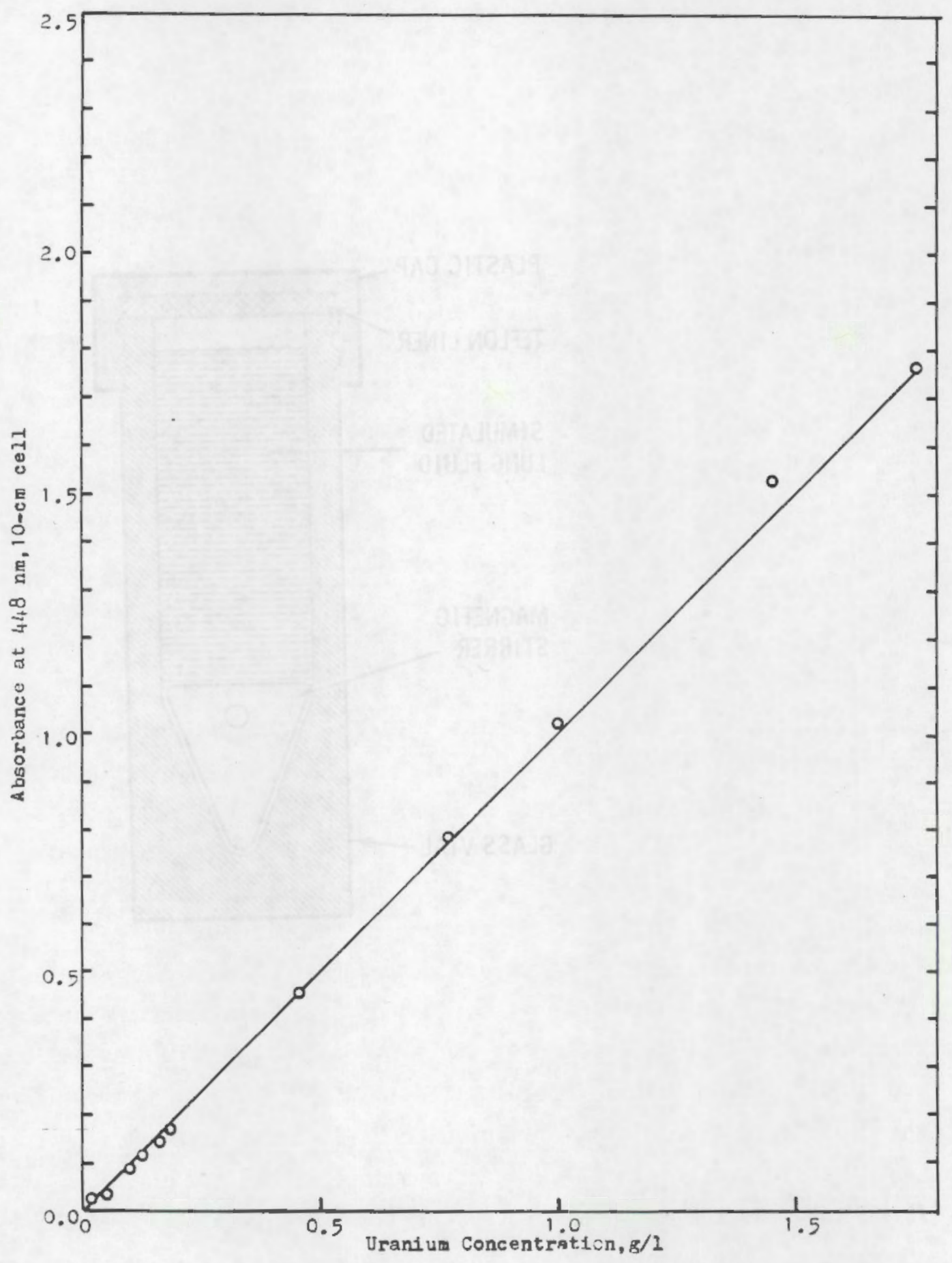


valence state of the dissolved uranium was uncertain, $3.0 \mathrm{~g}$ of periodic acid was dissolved in the 100-ml volume of filtrate, and the solution was heated to $80^{\circ} \mathrm{C}$ for one minute in order to convert all uranium to the hexavalent state. After this solution cooled to room temperature, its absorbance was measured in a 1-dm spectrophotometer cell at $425 \mathrm{~nm}$ versus a solution of similarly treated, uranium-free simulated lung fluid. The calibration curve for this assay is shown in Figure 5 . The concentration of uranium in a filtrate was obtained by dividing its absorbance by 0.577 , the absorptivity of uranium in $\ell g^{-1} \mathrm{dm}^{-1}$.

The filtrates obtained in dissolution trials using the sandwich or minibatch techniques were analyzed in two other ways. If the concentration of uranium exceeded $2 \times 10^{-5} \mathrm{~g} / \mathrm{l}$, the filtrate was analyzed by the method of Maeck, et al ${ }^{11}$, as modified by Rodden. ${ }^{12}$ Analysis consisted of acidifying $500 \mu \ell$ of filtrate with $500 \mu \ell$ of concentrated nitric acid in a 2-dram glass vial. A $0.004 \mathrm{~N}$ potassium permanganate solution was then added dropwise until the solution was pink in order to insure oxidation of any uranium to the hexavalent state. A drop of $0.04 \mathrm{~N}$ hydroxylamine hydrochloride was added subsequently to chemically reduce the excess permanganate. A 4.0-mi portion of $0.005 \mathrm{M}$ tetrapropylammonium hydroxide/2.8 $\mathrm{M}$ aluminum nitrate $(2.0 \mathrm{M}$ acid deficient) solution ${ }^{12}$ and $2.0^{\circ} \mathrm{ml}$ of hexone (methyl isobutyl ketone) were then added. The vial was closed with a plastic-lined screw cap and the contents were vigorously agitated on a vortex mixer to extract the tetrapropylammoniumuranium complex into the hexone phase. The hexone extract was transferred to a clean 2-dram vial and extracted with $5 \mathrm{ml}$ of an aqueous scrub solution to remove any metals that would interfere with the uranium analysis. The scrub solution contained $2.5 \mathrm{M}$ al uminum nitrate $(1.0 \mathrm{M}$ acid deficient), $0.22 \mathrm{M}$ tartaric acid, $0.25 \mathrm{M}$ oxalic acid, and $0.22 \mathrm{M}$ ethylenediaminetetraacetic acid. 11 A 1.00-ml aliquot of the scrubbed hexone solution was added to $15.0 \mathrm{ml}$ of $0.001 \mathrm{M}$ dibenzoylmethane (Eastman No. 2197) in 95\% pyridine/ $5 \%$ ethanol to form the colored uranium-dibenzoylmethane complex. This solution was transferred to a $5.00-\mathrm{cm}$ spectrophotometer cell, and its absorbance at $415 \mathrm{~nm}$ was measured verus a solution prepared from uranium-free SLF by the same procedure. The absorbance increased linearly with uranium concentration as shown in Figure 6, and the absorptivity was found to be $667 \mathrm{eg}^{-1} \mathrm{dm}^{-1}$. 
FIGURE 5. Calibration Curve for Uranium Assay in 0xidized Simulated Lung Fluid at $425 \mathrm{~nm}$

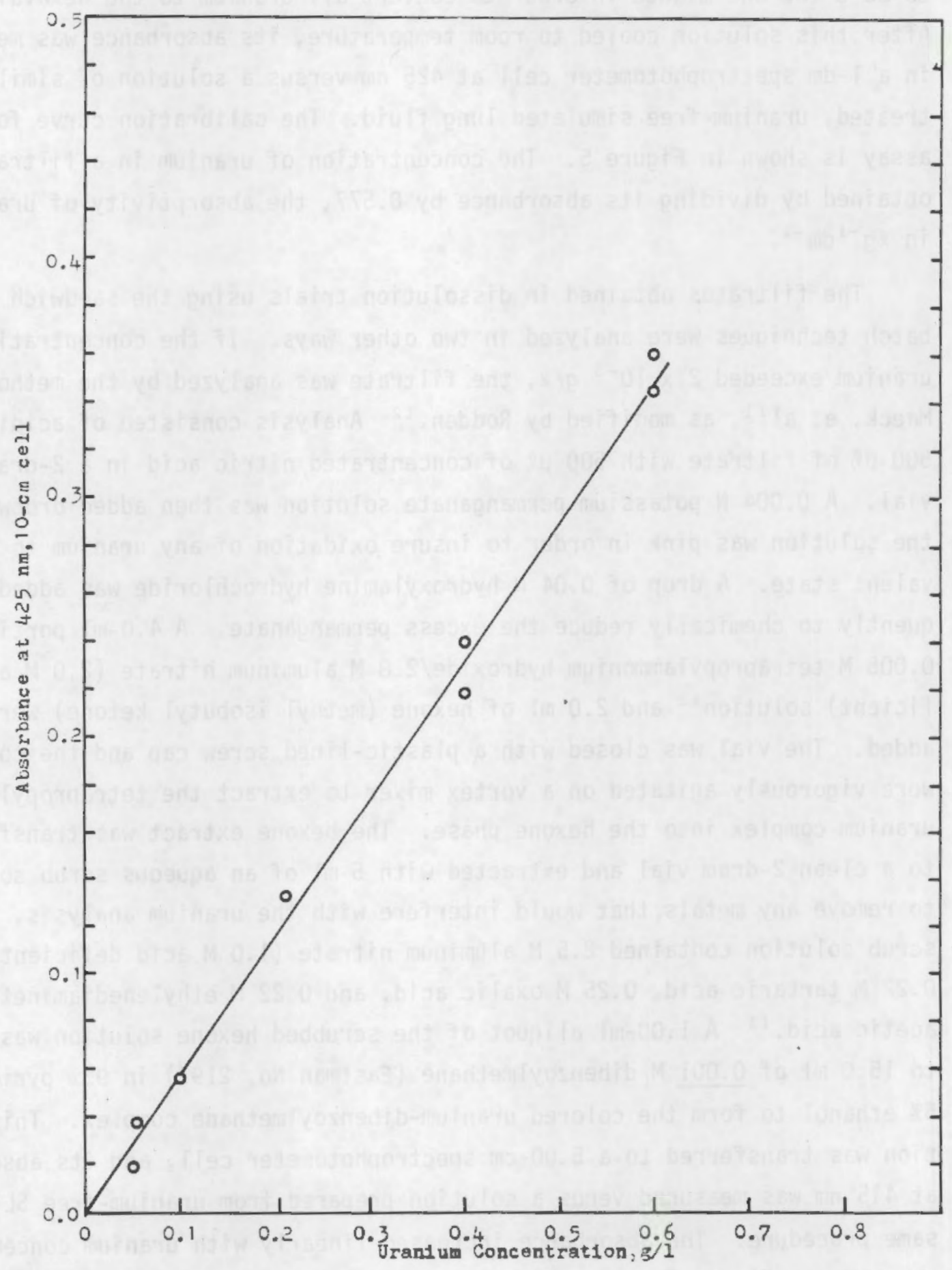


FIGURE 6. Calibration Curve for Uranium Assay as the Dibenzoylmethane Complex at $415 \mathrm{~nm}$

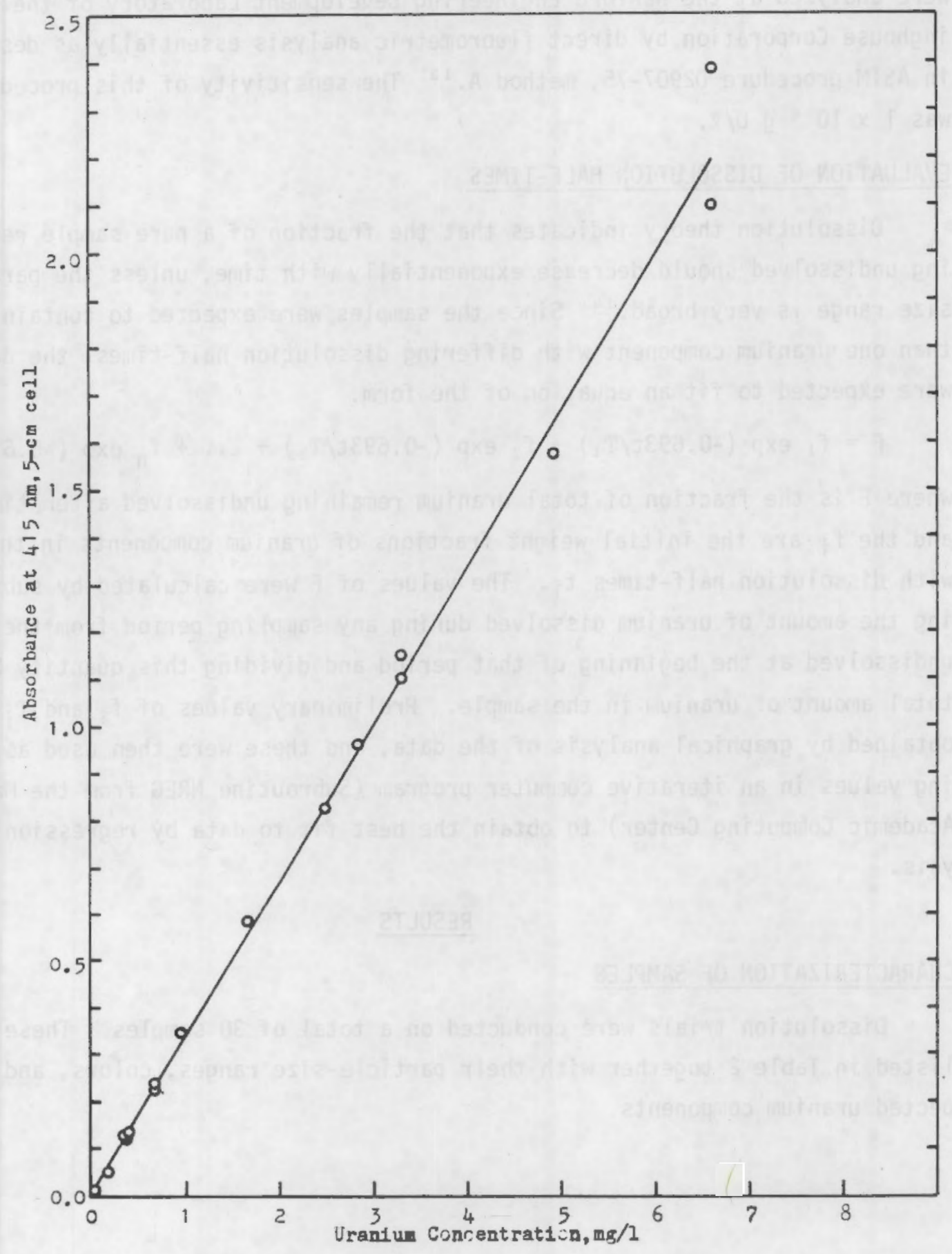


The concentration of uranium in the original filtrate was obtained in $\mathrm{g} / \mathrm{l}$ by multiplying the absorbance of the pyridine solution at 415 in a $5-\mathrm{cm}$ cell by $16 \times 2 \times 2 / 667 \times 0.5=0.192$. Filtrates containing less than $2 \times 10^{-5} \mathrm{~g} \mathrm{U} / \mathrm{l}$ were analyzed at the Hanford Engineering Development Laboratory of the Westinghouse corporation by direct fluorometric analysis essentially as described in ASTM procedure D2907-75, method A. ${ }^{13}$ The sensitivity of this procedure was $1 \times 10^{-6} \mathrm{~g} \mathrm{U} / \mathrm{l}$.

\section{EVALUATION OF DISSOLUTION HALF-TIMES}

Dissolution theory indicates that the fraction of a pure sample remaining undissolved should decrease exponentially with time, unless the particle size range is very broad. ${ }^{14}$ Since the samples were expected to contain more than one uranium component with differing dissolution half-times, the data were expected to fit an equation of the form:

$$
F=f_{1} \exp \left(-D .693 t / T_{1}\right)+f_{2} \exp \left(-0.693 t / T_{2}\right)+\ldots+f_{n} \exp \left(-0.693 t / T_{n}\right)
$$

where $F$ is the fraction of total uranium remaining undissolved after time $t$, and the $f_{j}$ are the initial weight fractions of uranium components in the sample with dissolution half-times $t_{j}$. The values of $F$ were calculated by subtracting the amount of uranium dissolved during any sampling period from the amount undissolved at the beginning of that period and dividing this quantity by the total amount of uranium in the sample. Preliminary values of $f_{i}$ and $T_{i}$ were obtained by graphical analysis of the data, and these were then used as starting values in an iterative computer program (Subroutine NREG from the Madison Academic Computing (enter) to obtain the best fit to data by regression analysis.

\section{RESULTS}

\section{CHARACTERIZATION OF SAMPLES}

Dissolution trials were conducted on a total of 30 samples. These are listed in Table 2 together with their particle-size ranges, colors, and expected uranium components. 
TABLE 2. Description of Samples

Sample

Anmonium diuranate

Uranium trioxide

Uranium octoxide

Uranium dioxide

Uranium tetrafluoride

Exxon Plant Oust

AOU granulator dis-
charge
AOU reduction kiln
discharge
Pellet grinder
U scrap recovery area
Babcock and Wilcox
Plant Oust

$U F_{6}$ hydrolyzer

AOU granulator discharge

AOU calciner discharge

$\mathrm{U}_{3} \mathrm{O}_{8}$ reduction kiln discharge

Pellet grinder

U scrap recovery area

U scrap dissolver

Westinghouse Plant Dust

ADU calciner feed

Sintering furnace discharge

U scrap recovery area

General Electric Oust

$\mathrm{UF}_{6}$ vaporization room

$\mathrm{UF}_{6}$ vaporizer/dissolver

ADU calciner feed

GECO calciner feed

ADU calciner discharge

GECO calciner discharge

Pellet press

Pellet grinder

Chem. room air, AOU end

Chem. room air, center

Chem. room air, GECO end

\begin{tabular}{llll}
\multicolumn{1}{c}{ Color } & Size Range & Expected Co \\
\cline { 1 - 2 } Yellow & $0-45 \mu \mathrm{m}$ & & $\left(\mathrm{NH}_{4}\right)_{2} \mathrm{U}_{2} \mathrm{O}_{7}$ \\
Yellow & $0-45 \mu \mathrm{m}$ & $\mathrm{UO}_{3}$ \\
Greenish black & $0-45 \mu \mathrm{m}$ & $\mathrm{U}_{3} \mathrm{O}_{8}$ \\
Brownish black & $0-45 \mu \mathrm{m}$ & $\mathrm{UO}_{2}$ \\
Green & $0-45 \mu \mathrm{m}$ & $\mathrm{UF}_{4}$
\end{tabular}

Yellow

$0-40 \mu m$

$\left(\mathrm{NH}_{4}\right)_{2} \mathrm{U}_{2} \mathrm{O}_{7}$

Brown

$0-10 \mu \mathrm{m}$

$\mathrm{UO}_{2}$

Brownish black

$0-25 \mu \mathrm{m}$

Black

$0-25 \mu \mathrm{m}$

$\mathrm{UO}_{2}$ (sint.)

$\mathrm{U}_{3} \mathrm{O}_{8}$

$\mathrm{UO}_{2} \mathrm{~F}_{2}$

Gray

$0-50 \mu \mathrm{m}$

$0-25 \mu \mathrm{m}$

$\left(\mathrm{NH}_{4}\right)_{2} \mathrm{U}_{2} \mathrm{O}_{7}$

Brown

$0-25 \mu \mathrm{m}$

$\mathrm{U}_{3} \mathrm{O}_{8}$

Brown

$0-10 \mu \mathrm{m}$

Brownish black

$0-25 \mu m$

Black

$0-25 \mu \mathrm{m}$

Yellow/black

$0-25 \mu \mathrm{m}$

$\mathrm{UO}_{2}$ (sint.)

$\mathrm{UO}_{2}\left(\mathrm{NO}_{3}\right)_{2}, \mathrm{U}_{3} \mathrm{O}_{8}$

$\mathrm{UO}_{2}\left(\mathrm{NO}_{3}\right)_{2}$

Yellow brown $\quad 0-10 \mu \mathrm{m}$

Brownish black $0-10 \mu \mathrm{m}$

Gray

$0-10 \mu m$

$\left(\mathrm{NH}_{4}\right)_{2} \mathrm{U}_{2} \mathrm{O}_{7}, \mathrm{U}_{3} \mathrm{O}_{8}$

$\mathrm{UO}_{2}$ (sint.)

$\mathrm{UO}_{2}\left(\mathrm{NO}_{3}\right)_{2}, \mathrm{U}_{3} \mathrm{O}_{8}$

Gray $\quad 0-50 \mu m$

$\mathrm{UF}_{6}, \mathrm{UO}_{2} \mathrm{~F}_{2}$

$0-25 \mu m$

$0-10 \mu m$

$0-5 \mu m$

$0-50 \mu \mathrm{m}$

$0-50 \mu \mathrm{m}$

$0-10 \mu \mathrm{m}$

$0-5 \mu \mathrm{m}$

$0-50 \mu \mathrm{m}$

$0-50 \mu \mathrm{m}$

$0-50 \mu m$

$\mathrm{UO}_{2} \mathrm{~F}_{2}$

$\left(\mathrm{NH}_{4}\right)_{2} \mathrm{U}_{2} \mathrm{O}_{7}$

$\mathrm{UO}_{2} \mathrm{~F}_{2}, \mathrm{UF}_{4}, \mathrm{U}_{3} \mathrm{O}_{3}, \mathrm{UO}_{2}$

$\mathrm{U}_{3} \mathrm{O}_{8}, \mathrm{UO}_{2}$

$\mathrm{U}_{3} \mathrm{O}_{8}, \mathrm{UO}_{2}$

$\mathrm{UO}_{2}$

$\mathrm{UO}_{2}$

All of above

All of above

All of above 
Microprobe and $\mathrm{X}$-ray crystallographic analyses of a randomly selected particle from three of the samples obtained from the Exxon Nuclear $C_{0}$. are tabulated below.

TABLE 3. Microprobe and X-Ray Crystallographic Analyses of Individual Particles

\begin{tabular}{lcll} 
Sample & Microprobe Assay & & Crystal Form \\
\cline { 4 - 5 } ADU reduction kiln (Exxon) & $83 \% \mathrm{U}$ & & Cubic $\mathrm{UO}_{2}$ \\
Pellet grinder (Exxon) & $85 \% \mathrm{U}$ & & Cubic $\mathrm{UO}_{2}$ \\
$\mathrm{U}$ scrap recovery (Exxon) & $77 \% \mathrm{U}$ & Hexagonal $\mathrm{U}_{3} \mathrm{O}_{8}$
\end{tabular}
DISSOLUTION BEHAVIOR OF SAMPLES

The dissolution behavior of the samples is shown graphically in Figures 7 to 36 . Most of the graphs consist of a single curve; however, those for uranium trioxide (Figure 9) and ammonium diuranate (Figure 11) show multiple sets of data. In Figure 9, dissolution patterns obtained for $\mathrm{UO}_{3}$ by both the batch and mini-batch techniques are compared and shown to be quite similar. In Figure 11, dissolution patterns for $\left(\mathrm{NH}_{4}\right)_{2} \mathrm{U}_{2} \mathrm{O}_{7}$ by both the mini-batch and sandwich methods are compared and shown to be identical. Also shown in Figure 11 are dissolution patterns for portions of this sample by the batch method both 15 months earlier and 9 months later than this comparison. The steady increase in dissolution half-time suggests that chemical changes occurred in the sample during storage in air at $23^{\circ} \mathrm{C}$. The uranium content of the sample was also found to increase from $74.6 \%$ in Apri1, 1978 to $76.7 \%$ two years later.

The importance of bicarbonate ion in the dissolution of uranium is also shown in Figure 11 , where the non-dissolution of $\left(\mathrm{NH}_{4}\right)_{2} \mathrm{U}_{2} \mathrm{O}_{7}$ in bicarbonatefree SLF is depicted. Figure 37 shows the optical absorption spectrum of $\left(\mathrm{NH}_{4}\right)_{2} \mathrm{U}_{2} \mathrm{O}_{7}$ dissolved in regular SLF, and it corresponds closely to published spectra of the $\left[\mathrm{UO}_{2}\left(\mathrm{CO}_{3}\right)_{3}\right]^{4-}$ anion. ${ }^{15}$ Similar spectra, differing only in absorption intensity, were obtained for all the samples that underwent appreciable dissolution.

The dissolution data were fitted into expressions of the form: $F=f_{1} \exp \left(-0.693 t / T_{1}\right)+f_{2} \exp \left(-0.693 t / T_{2}\right)-f_{3} \exp \left(-0.693 t / T_{3}\right)+\ldots$ 
FIGURE 7. Dissolution of Uranium Dioxide Dust, Obtained from the New Brunswick Laboratory, into Simulated Lung Fluid at $37^{\circ} \mathrm{C}$

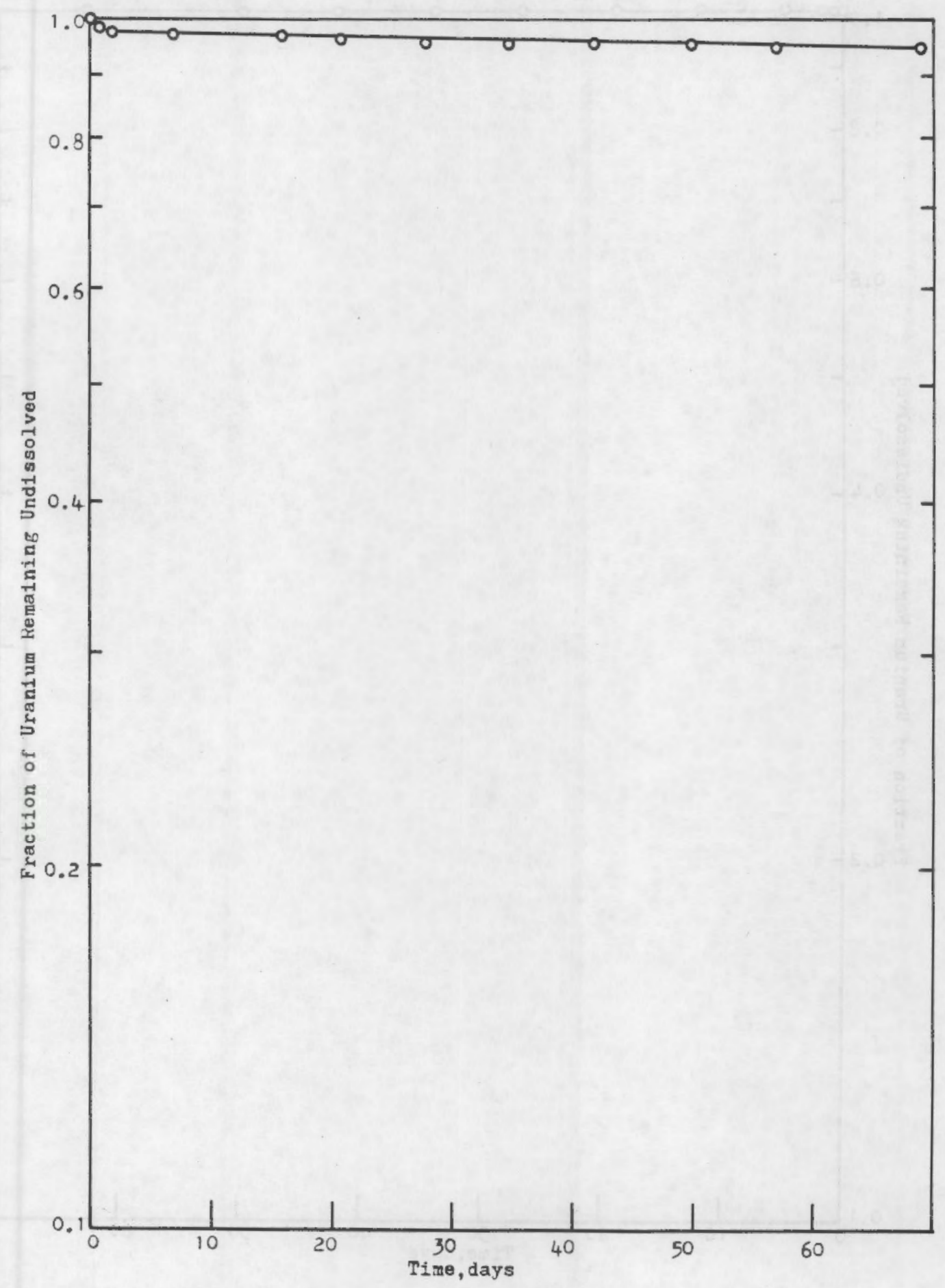


FIGURE 8. Dissolution of Uranium Octoxide Dust, Obtained from the New Brunswick Laboratory, into Simulated Lung Fluid at $37^{\circ} \mathrm{C}$

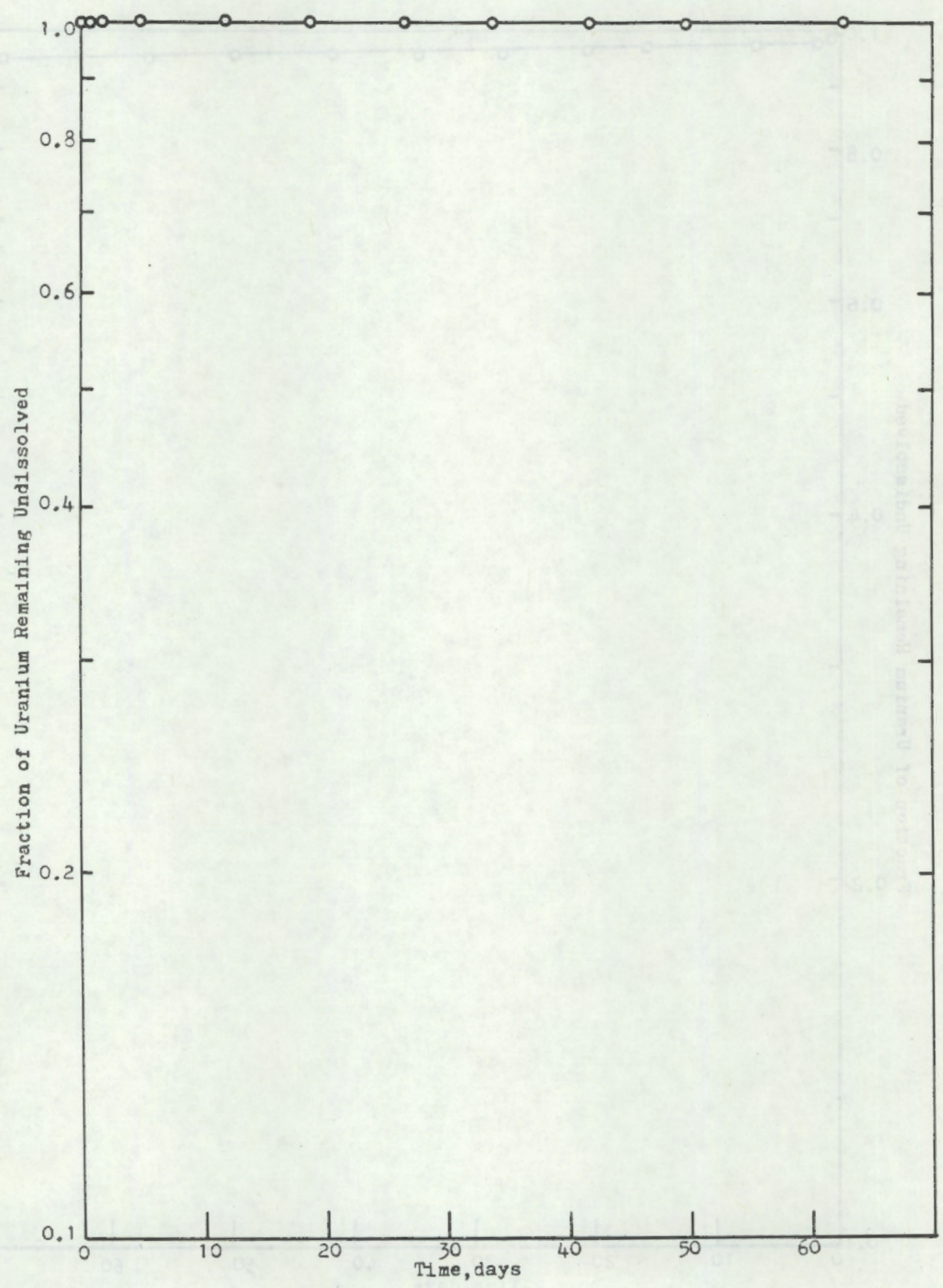


FIGURE 9. Dissolution of Uranium Trioxide Dust, Obtained from the New Brunswick Laboratory, into Simulated Lung Fluid at $37^{\circ} \mathrm{C}$. (Data from batch method shown by open circles. Data from mini-batch method shown by closed circles.)

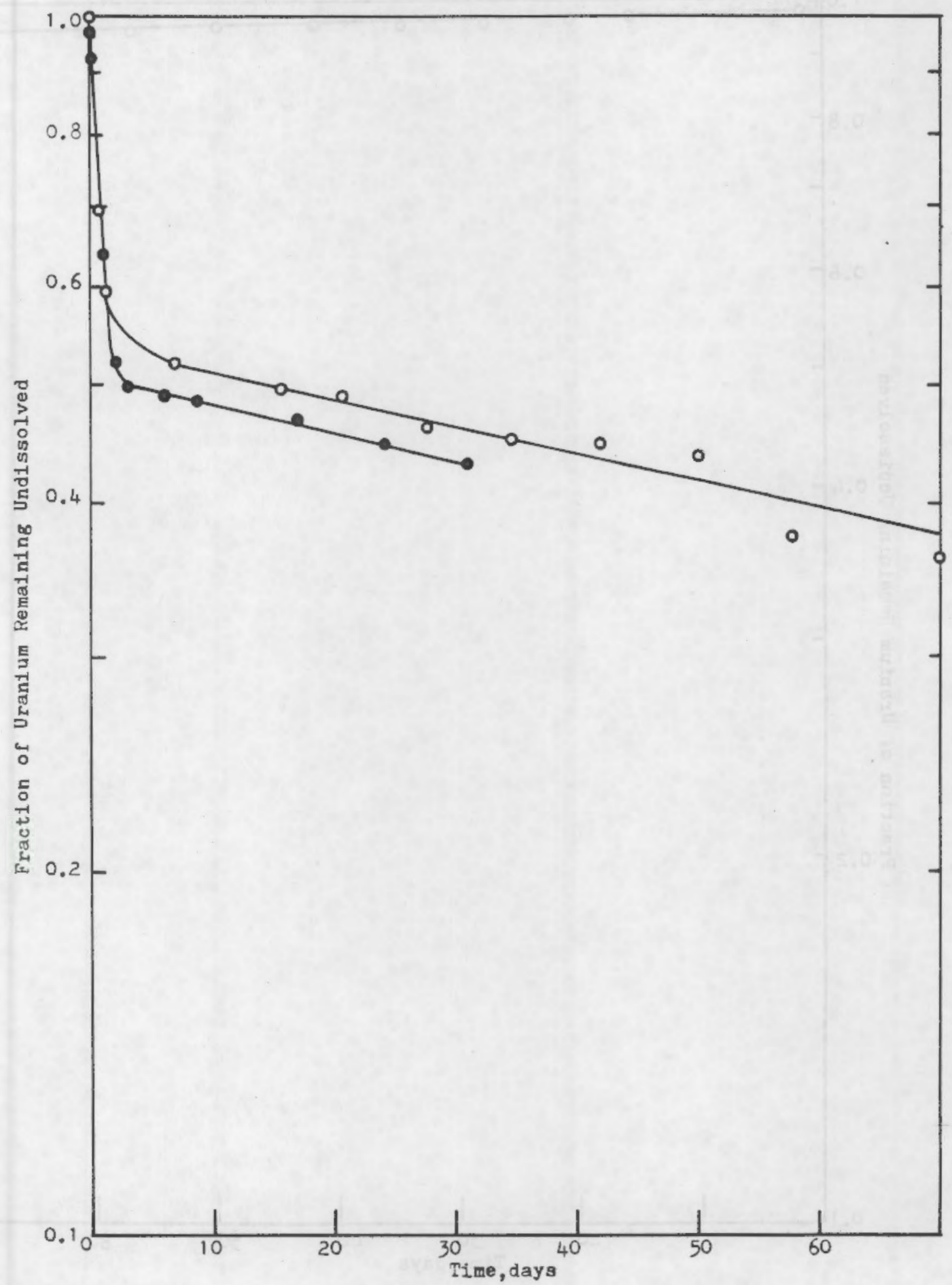


FIGURE 10. Dissolution of Uranium Tetrafluoride Oust, Obtained from the New Brunswick Laboratory, into Simulated Lung Fluid at $37^{\circ} \mathrm{C}$

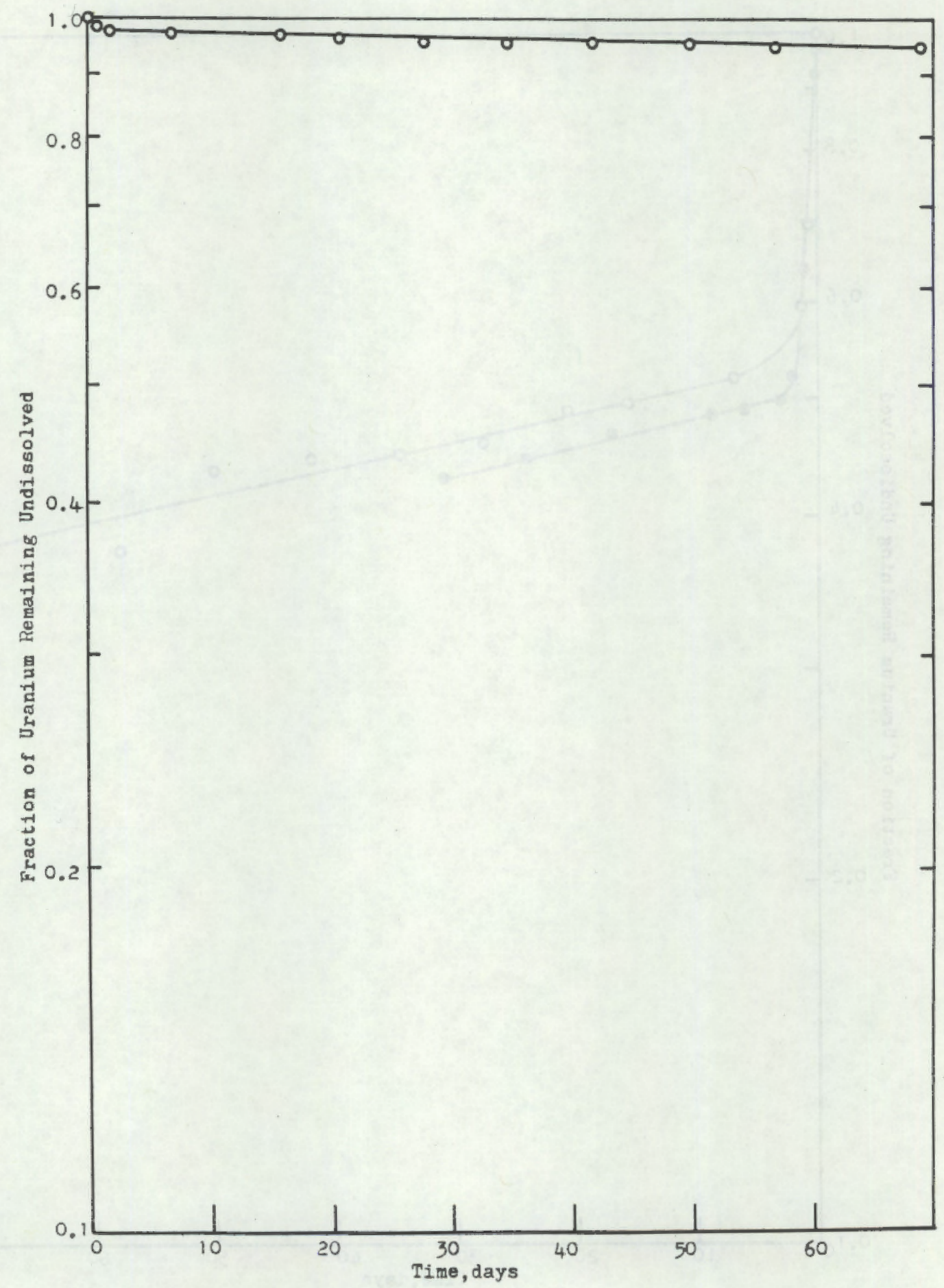


FIGURE 11. Dissolution of Ammonium Diuranate Dust, Obtained from the Westinghouse Corporation, into Simulated Lung Fluid at $37^{\circ} \mathrm{C}$. Data from April 1978, batch method (0); July 1979, sandwich $(\Delta)$ and mini-batch ( $\mathbf{\Lambda}$ ) methods; and March 1980, batch method ( $\mathrm{a}$ ). Dissolution into bicarbonate-free simulated lung fluid, mini-batch method ( $)$.

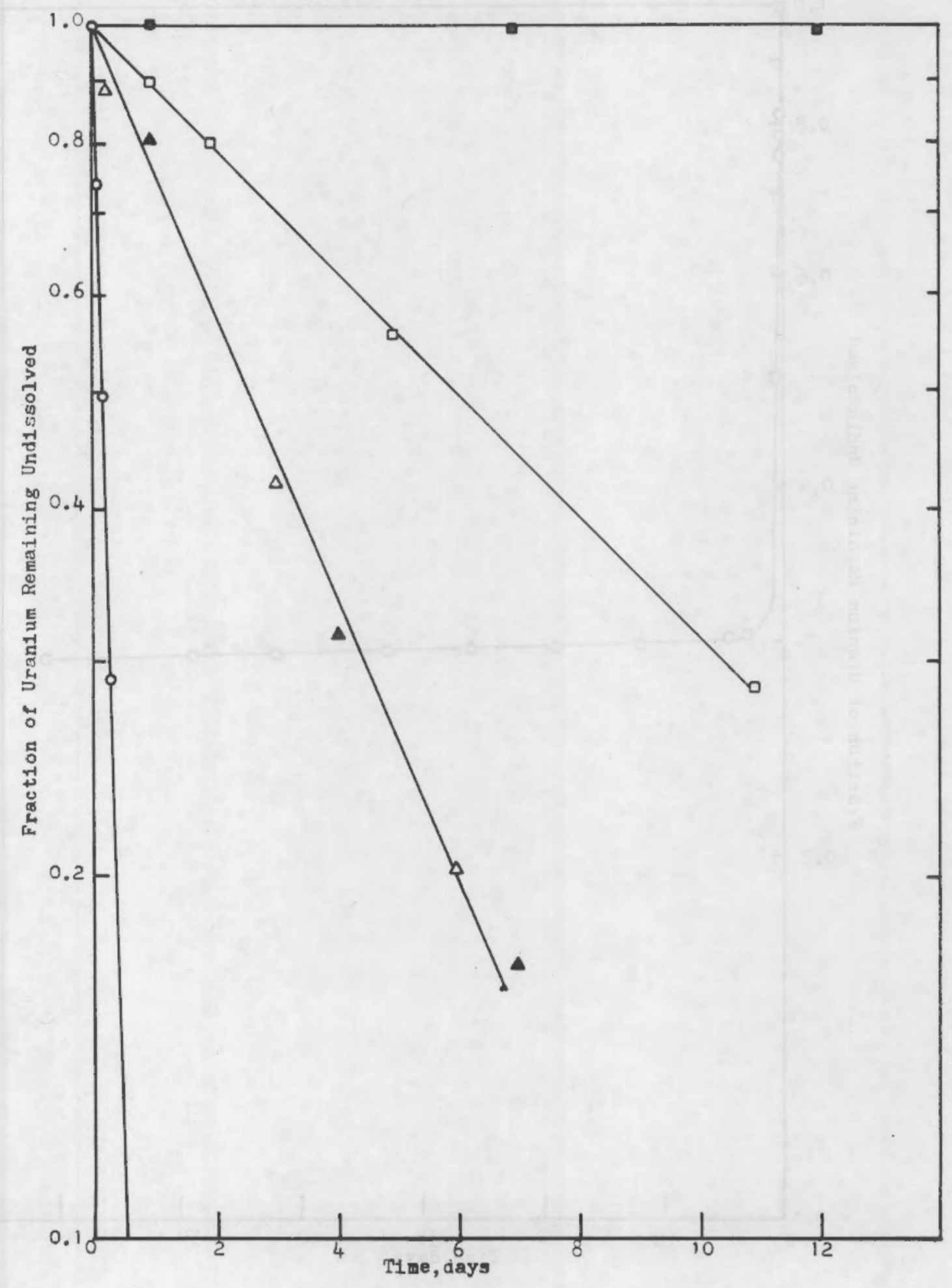


FIGURE 12. Dissolution of Dust, Collected at Exxon's ADU Granulator Discharge, into Simulated Lung Fluid at $37^{\circ} \mathrm{C}$

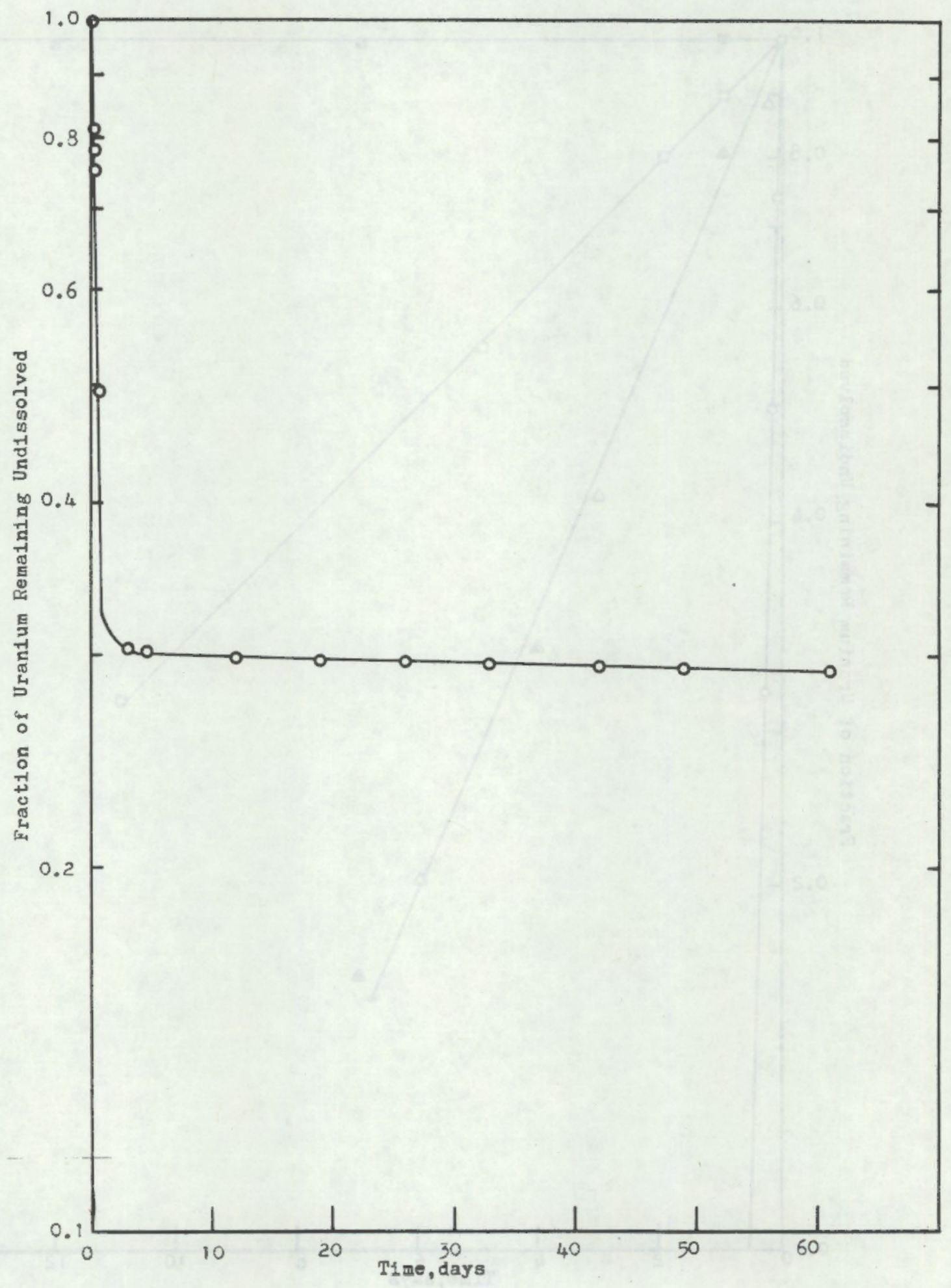


FIGURE 13. Dissolution of Dust, Collected at Exxon's ADU. Calciner Discharge, into Simulated Lung Fluid at $37^{\circ} \mathrm{C}$

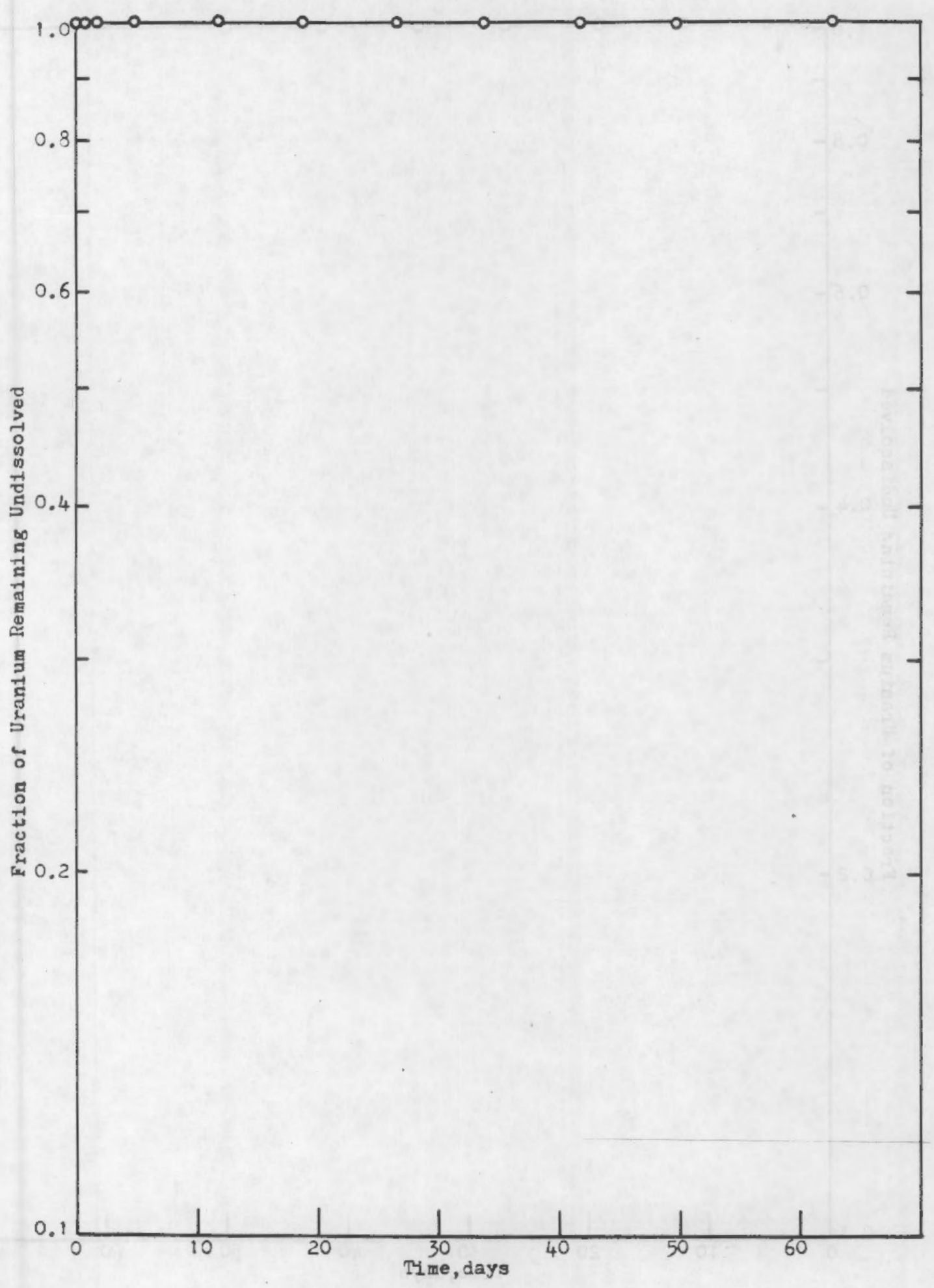


FIGURE 14. Dissolution of Dust, Collected at Exxon's Pellet Grinder, into Simulated Lung Fluid at $37^{\circ} \mathrm{C}$

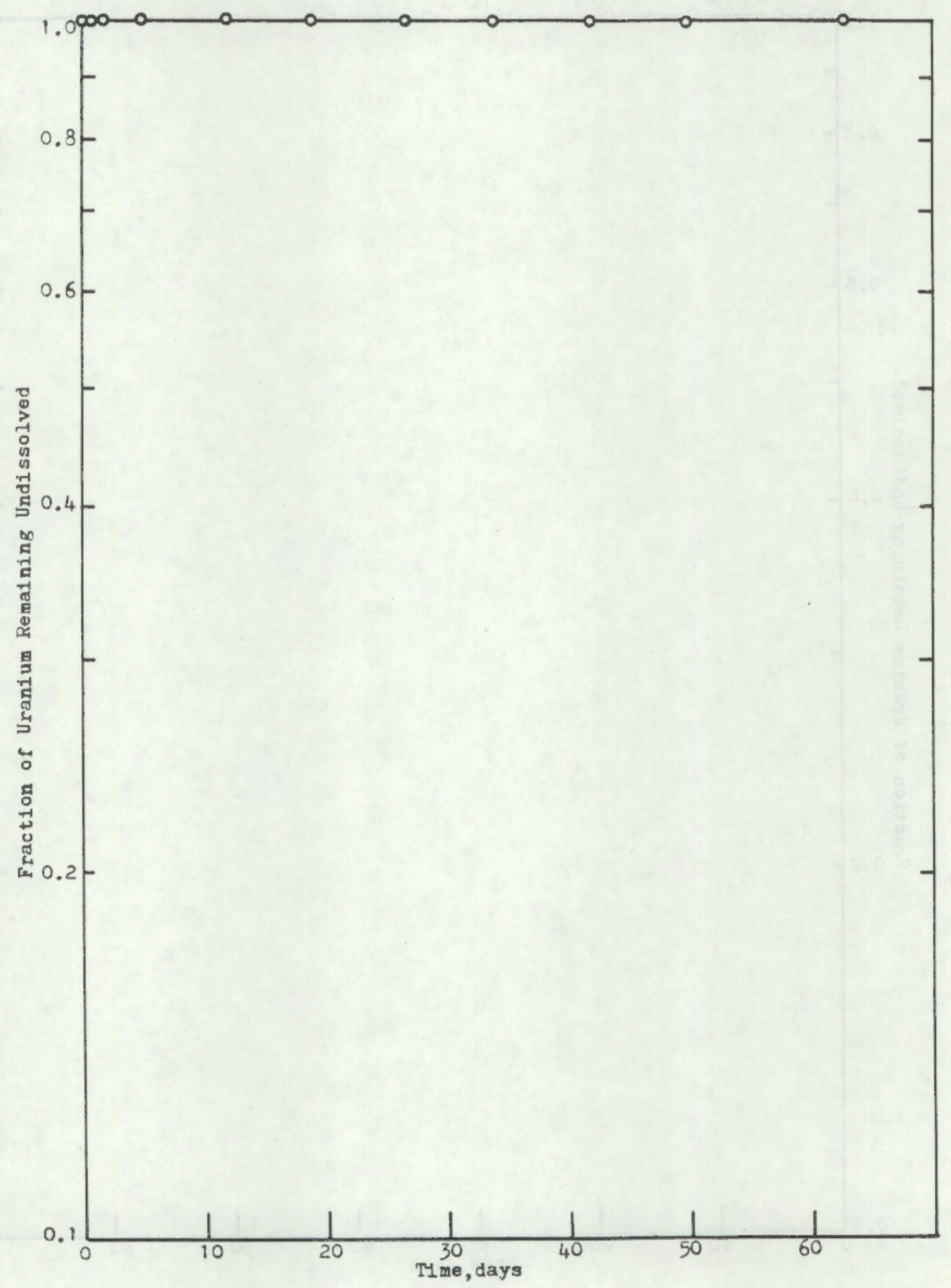


FIGURE 15. Dissolution of Dust, Collected at Exxon's Scrap Recovery Area, into Simulated Lung Fluid at $37^{\circ} \mathrm{C}$

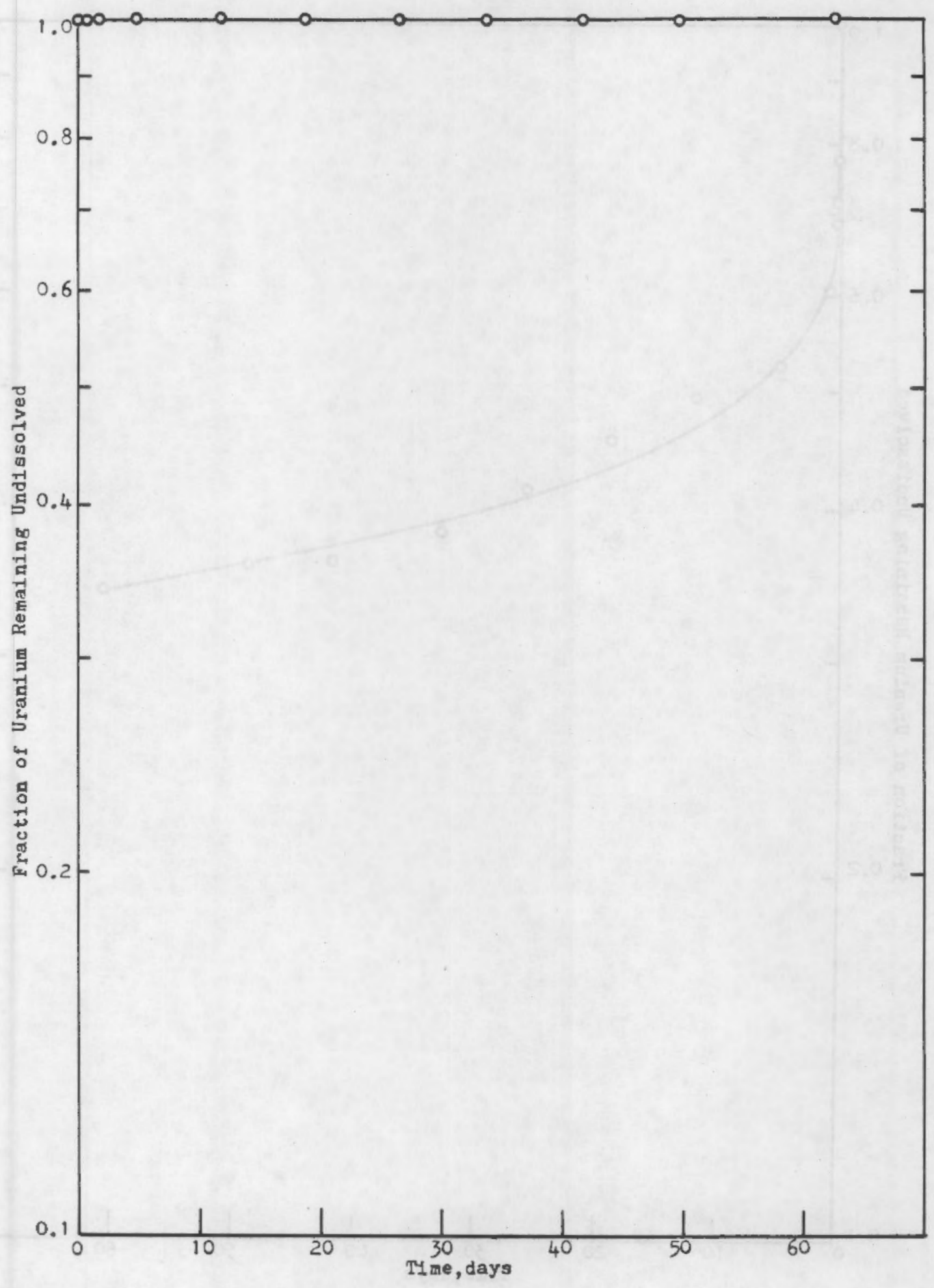


FIGURE 16. Dissolution of Dust, Collected at Babcock \& Wilcox's UF 6 Hydrolyzer, into Simulated Lung Fluid at $37^{\circ} \mathrm{C}$

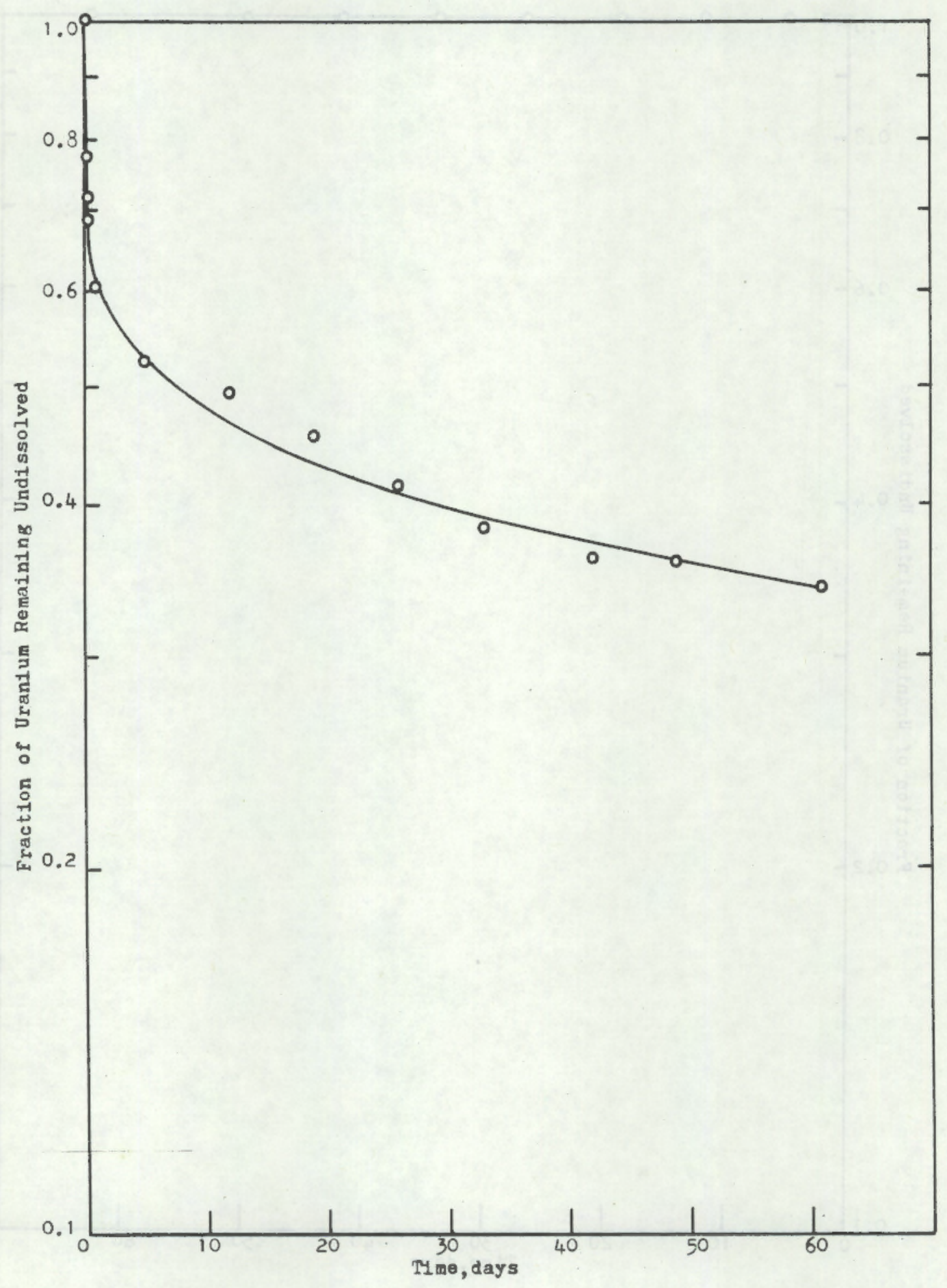


FIGURE 17. Dissolution of Dust, Collected at Babcock \& Wilcox's ADU Granulator Discharge, into Simulated Lung Fluid at $37^{\circ} \mathrm{C}$

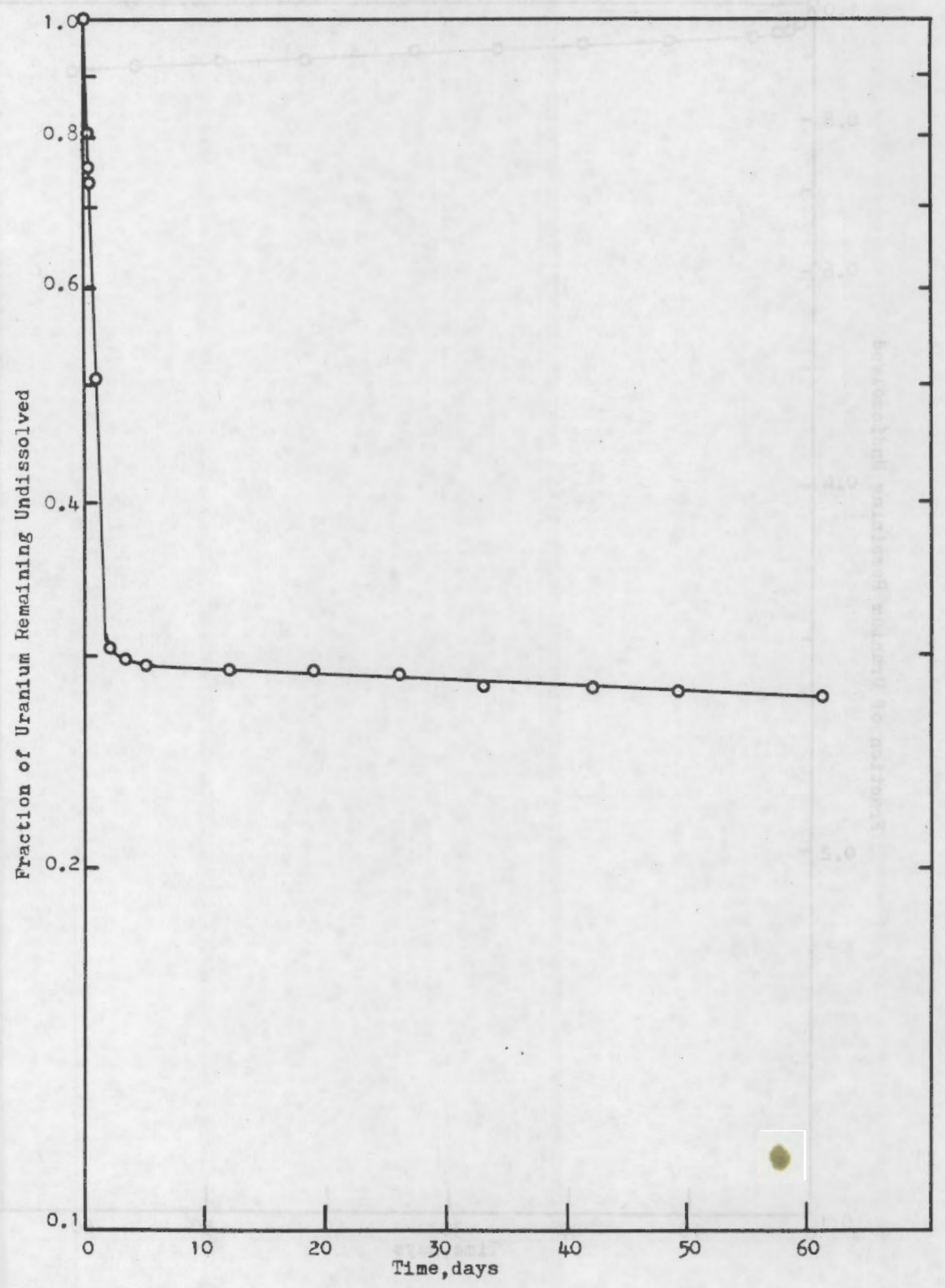


FIGURE 18. Dissolution of Dust, Collected at Babcock \& Wilcox's ADU Calciner Discharge, into Simulated Lung Fluid at $37^{\circ} \mathrm{C}$

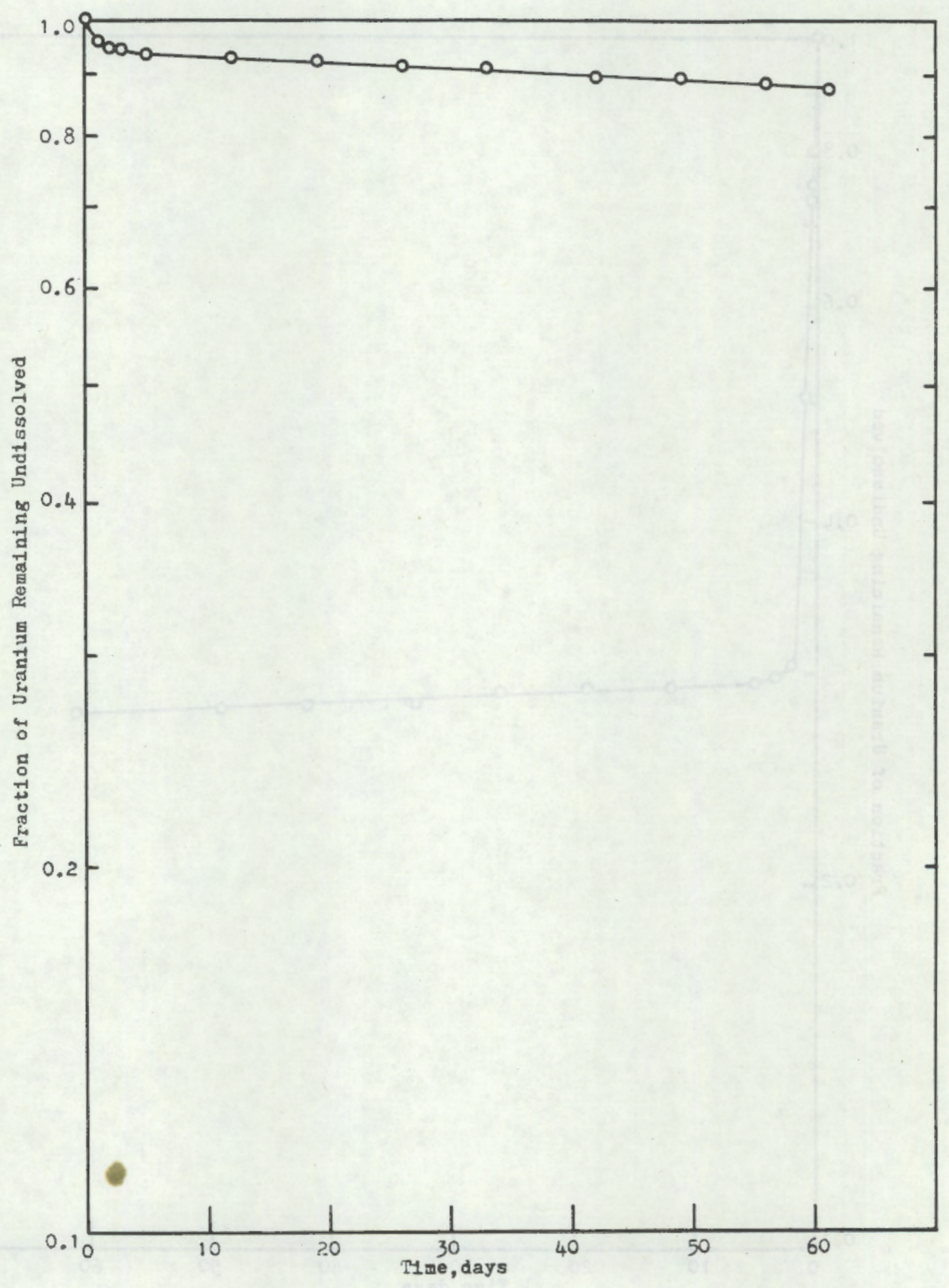


FIGURE 19. Dissolution of Dust, Collected at Babcock \& Wilcox's Reduction Kiln Discharge, into Simulated Lung Fluid at $37^{\circ} \mathrm{C}$

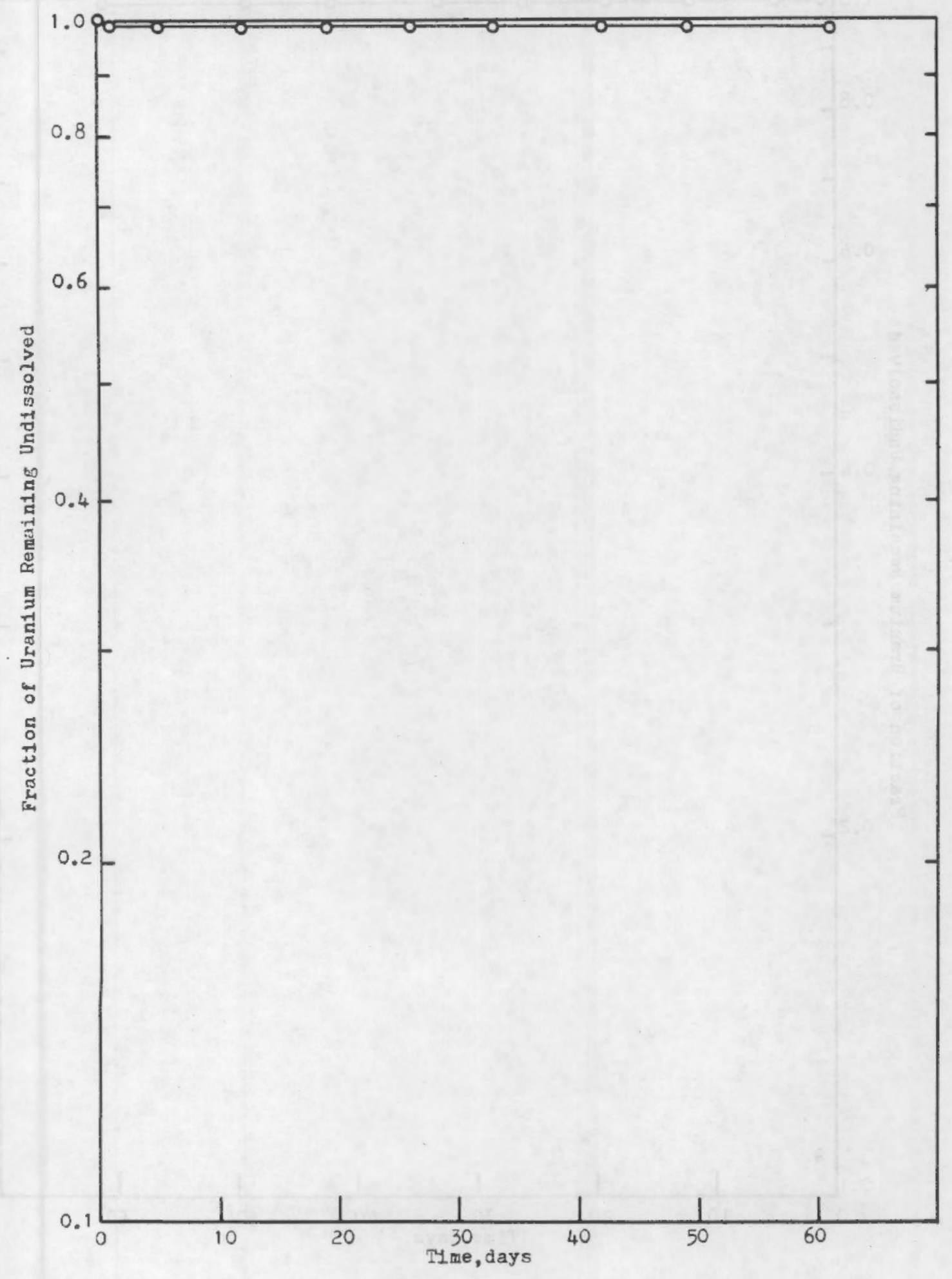


FIGURE 20. Dissolution of Dust, Collected at Babcock \& Wilcox's Pellet Grinders, into Simulated Lung Fluid at $37^{\circ} \mathrm{C}$

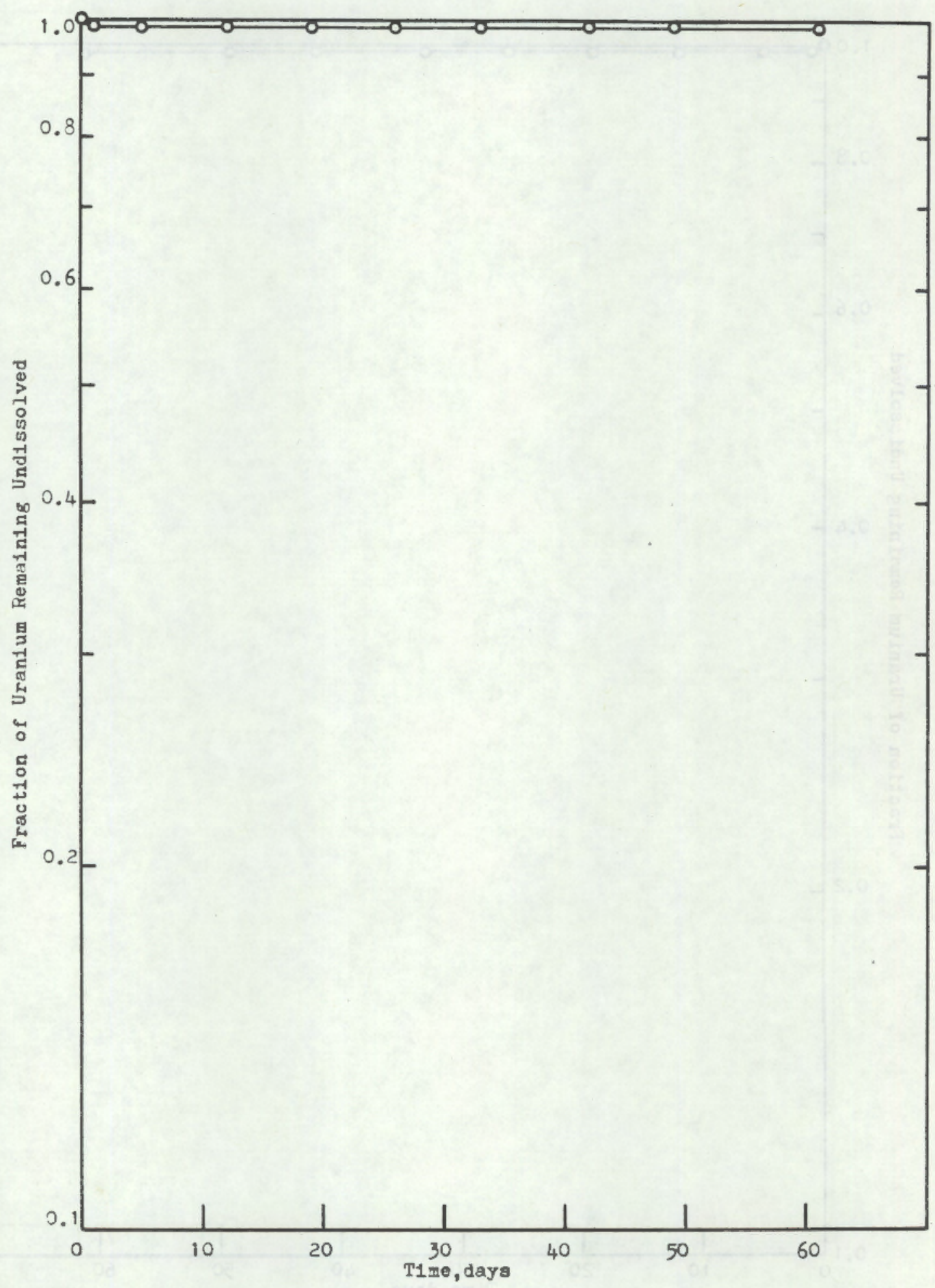


FIGURE 21. Dissolution of Dust, Collected at Babcock \& Wilcox's Uranium Scrap Recovery Area, into Simulated Lung Fluid at $37^{\circ} \mathrm{C}$

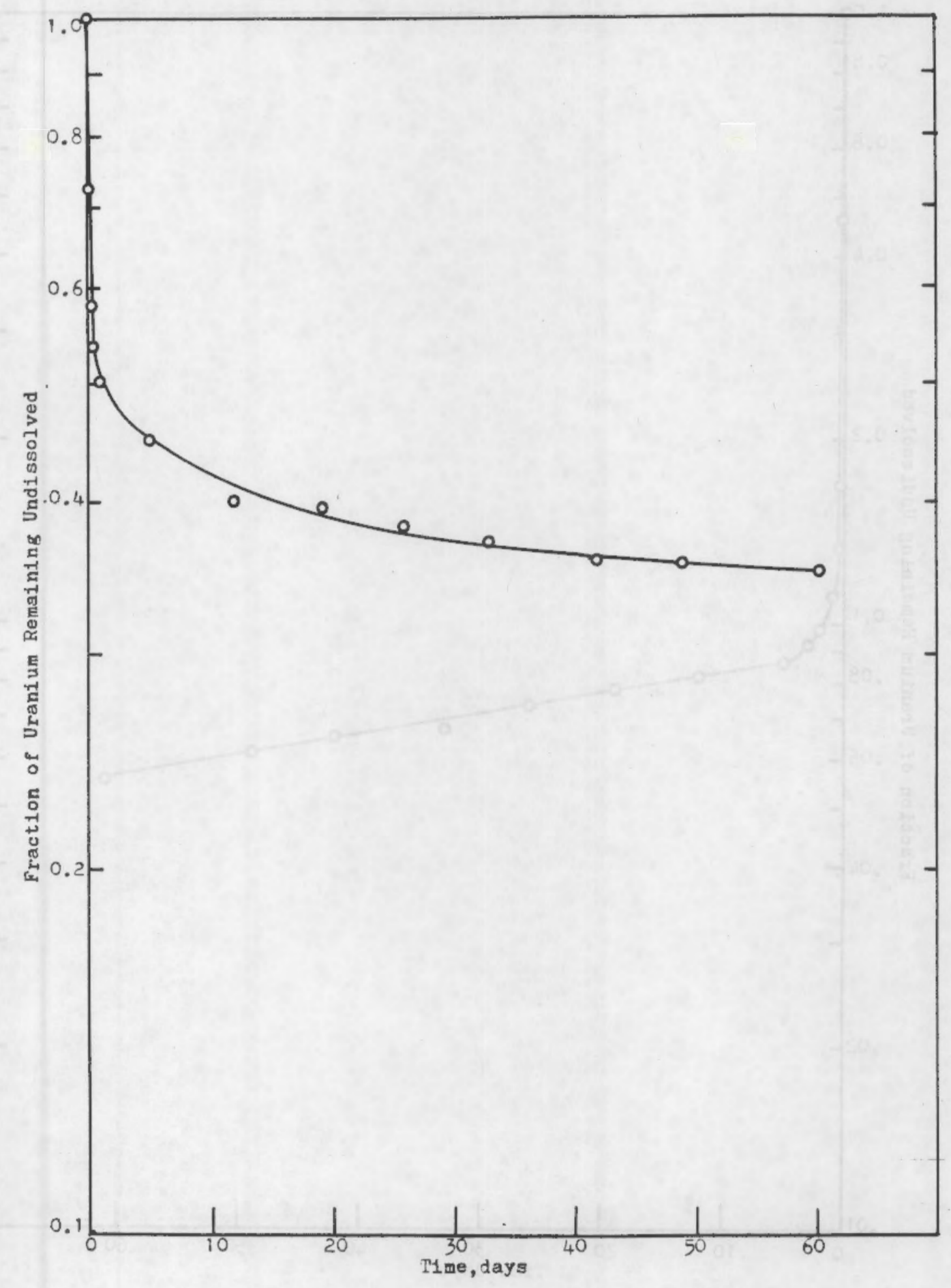


FIGURE 22. Dissolution of Dust, Collected at Babcock \& Wilcox's Uranium Scrap Dissolver, into Simulated Lung Fluid at $37^{\circ} \mathrm{C}$

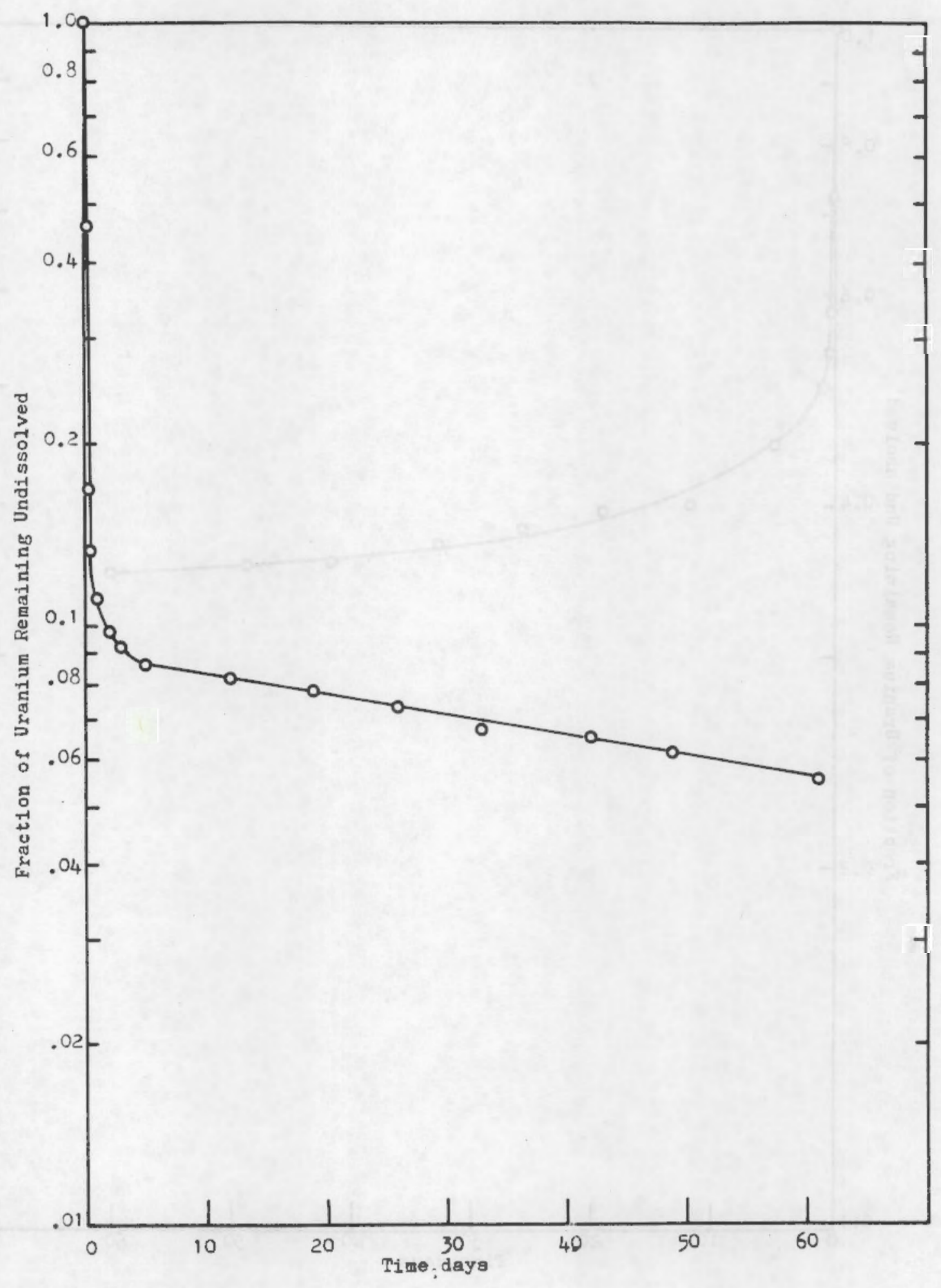


FIGURE 23. Dissolution of Dust, Collected at Westinghouse's ADU Granulator Discharge, into Simulated Lung Fluid at $37^{\circ} \mathrm{C}$

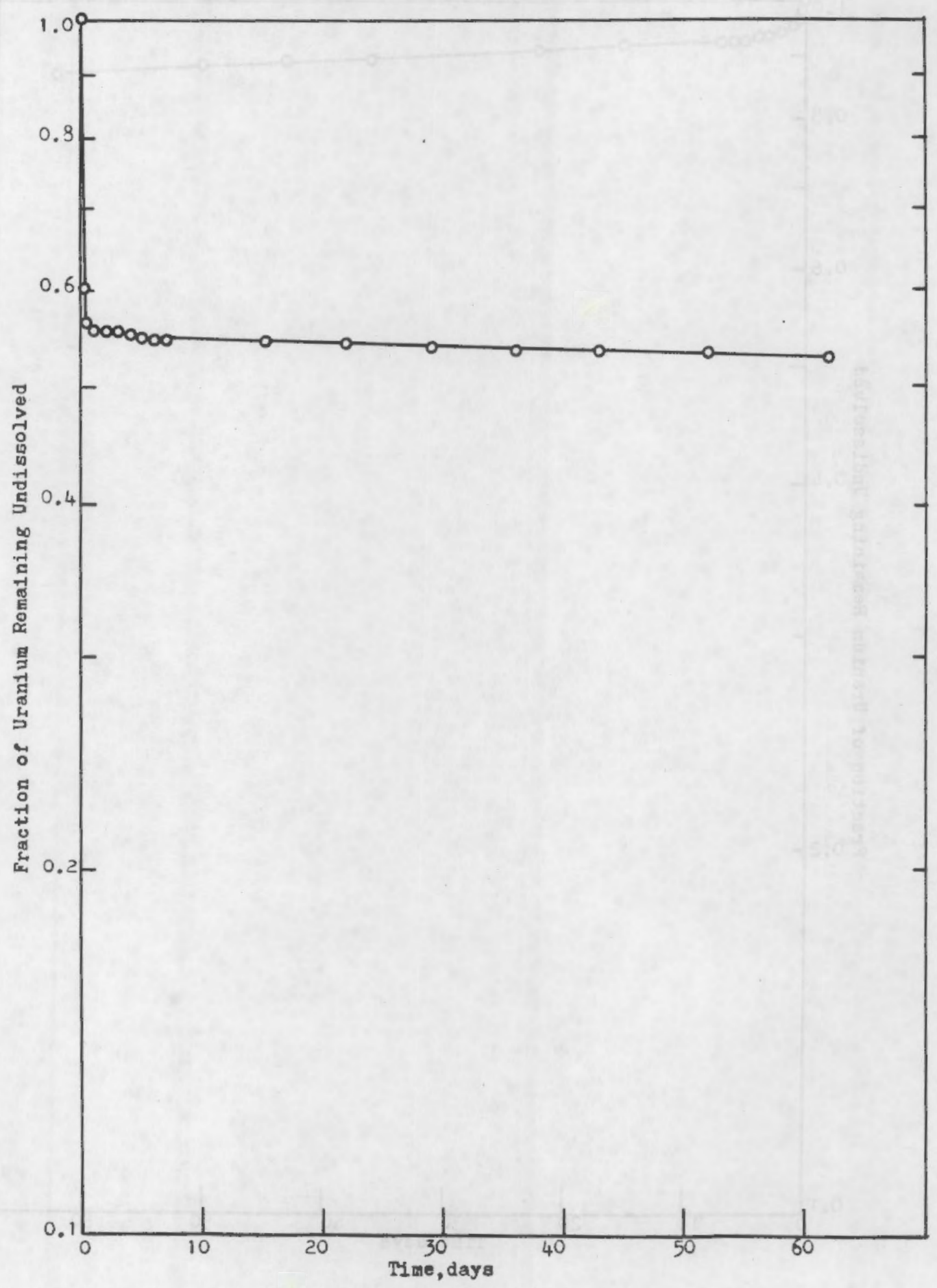


FIGURE 24. Dissolution of Dust Collected at Westinghouse's Sintering Furnace Feed, into Simulated Lung F7uid at $37^{\circ} \mathrm{C}$

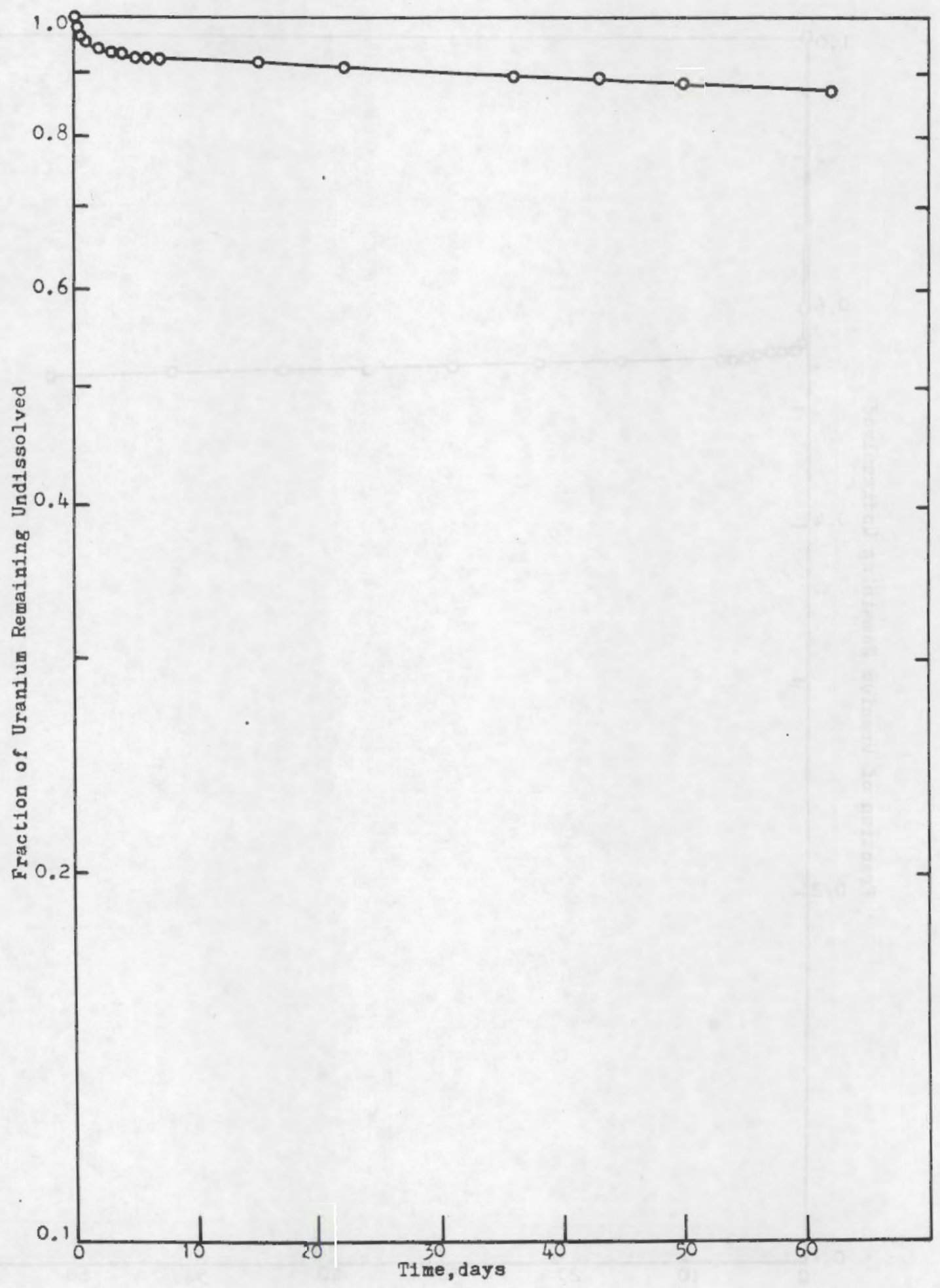


FIGURE 25. Dissolution of Dust Collected at Westinghouse's Uranium Scrap Recovery Area, into Simulated Lung Fluid at $37^{\circ} \mathrm{C}$

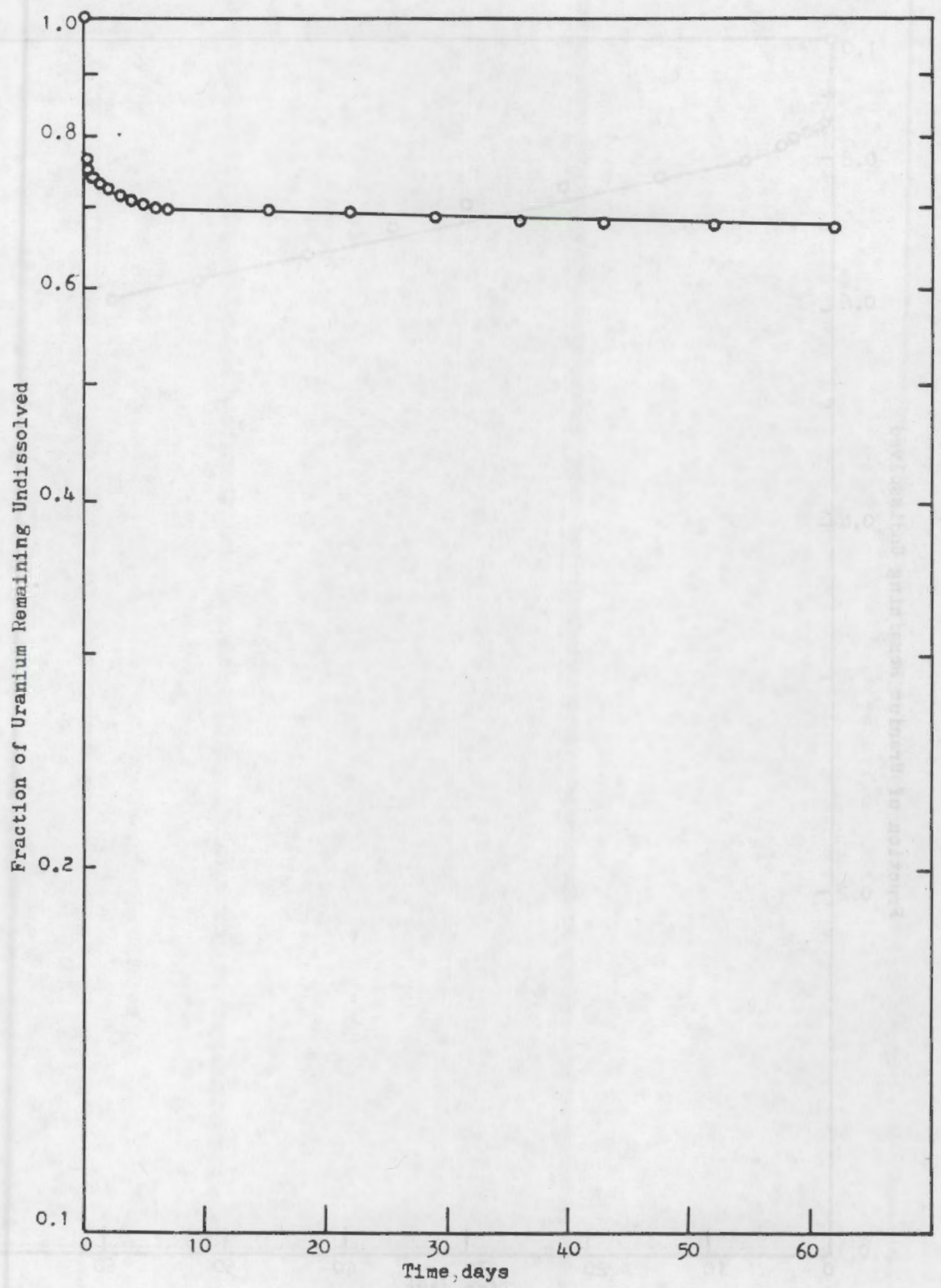


FIGURE 26. Dissolution of Dust Collected at General Electric's UF $_{6}$ Vaporization Room, into Simulated Lung Fluid at $37^{\circ} \mathrm{C}$

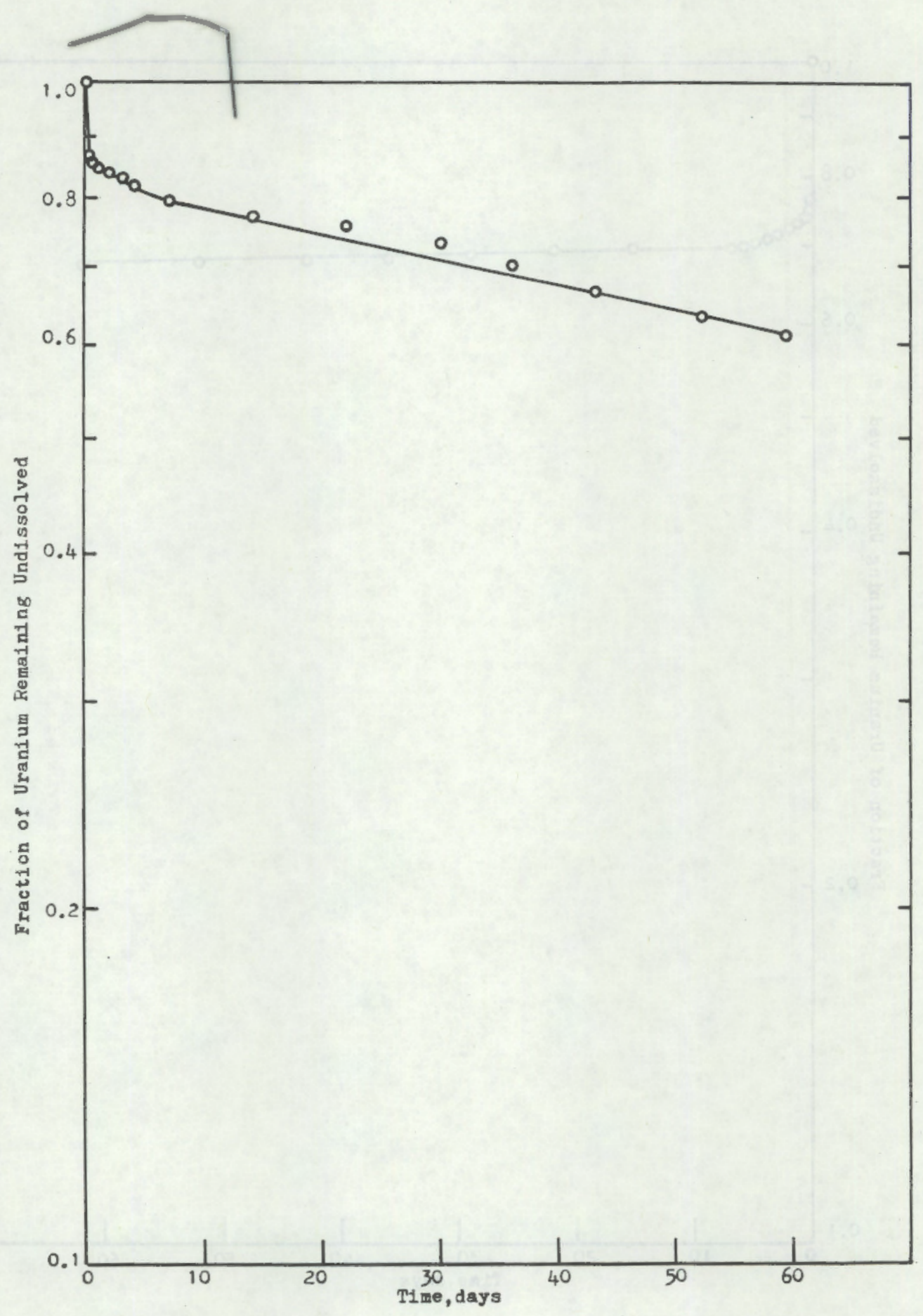


FIGURE 27. Dissolution of Dust, Collected at General Electric's UF 6 Hydrolyzer, into Simulated Lung Fluid at $37^{\circ} \mathrm{C}$

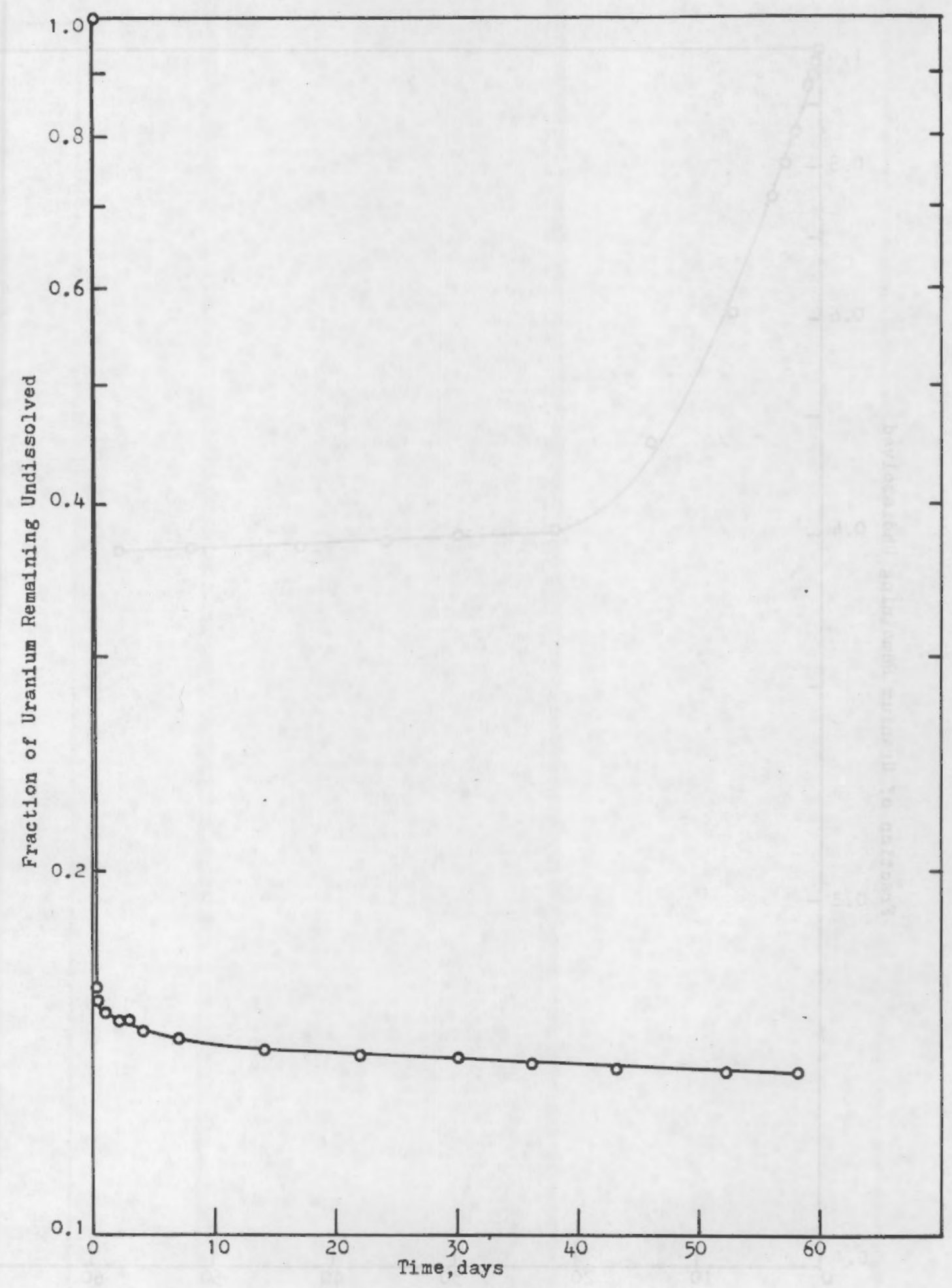


FIGURE 28. Dissolution of Dust, Collected at General Electric's ADU Calciner Feed, into Simulated Lung Fluid at $37^{\circ} \mathrm{C}$

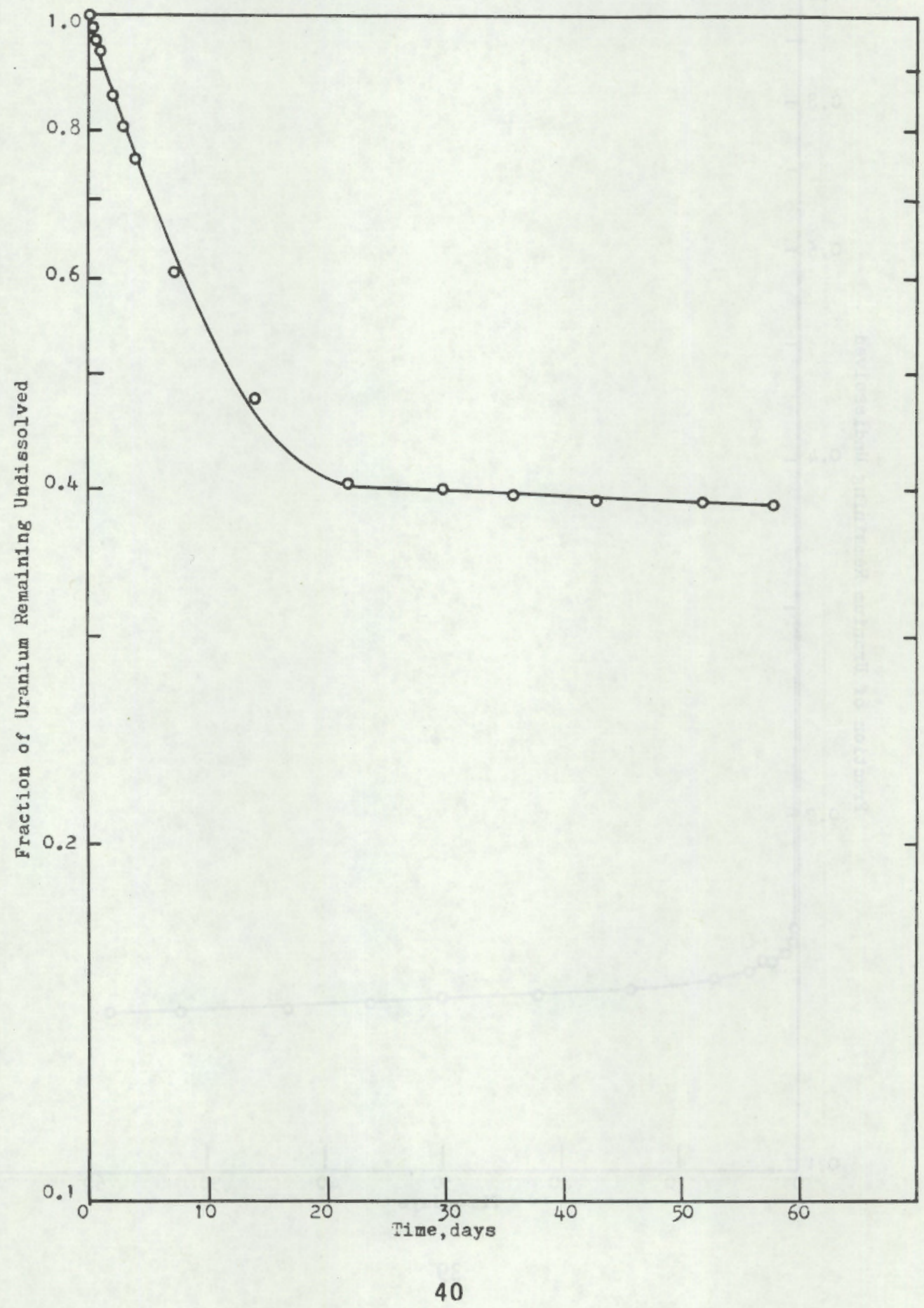


FIGURE 29. Dissolution of Dust, Collected at General Electric's GECO Calciner Feed, into Simulated Lung Fluid at $37^{\circ} \mathrm{C}$

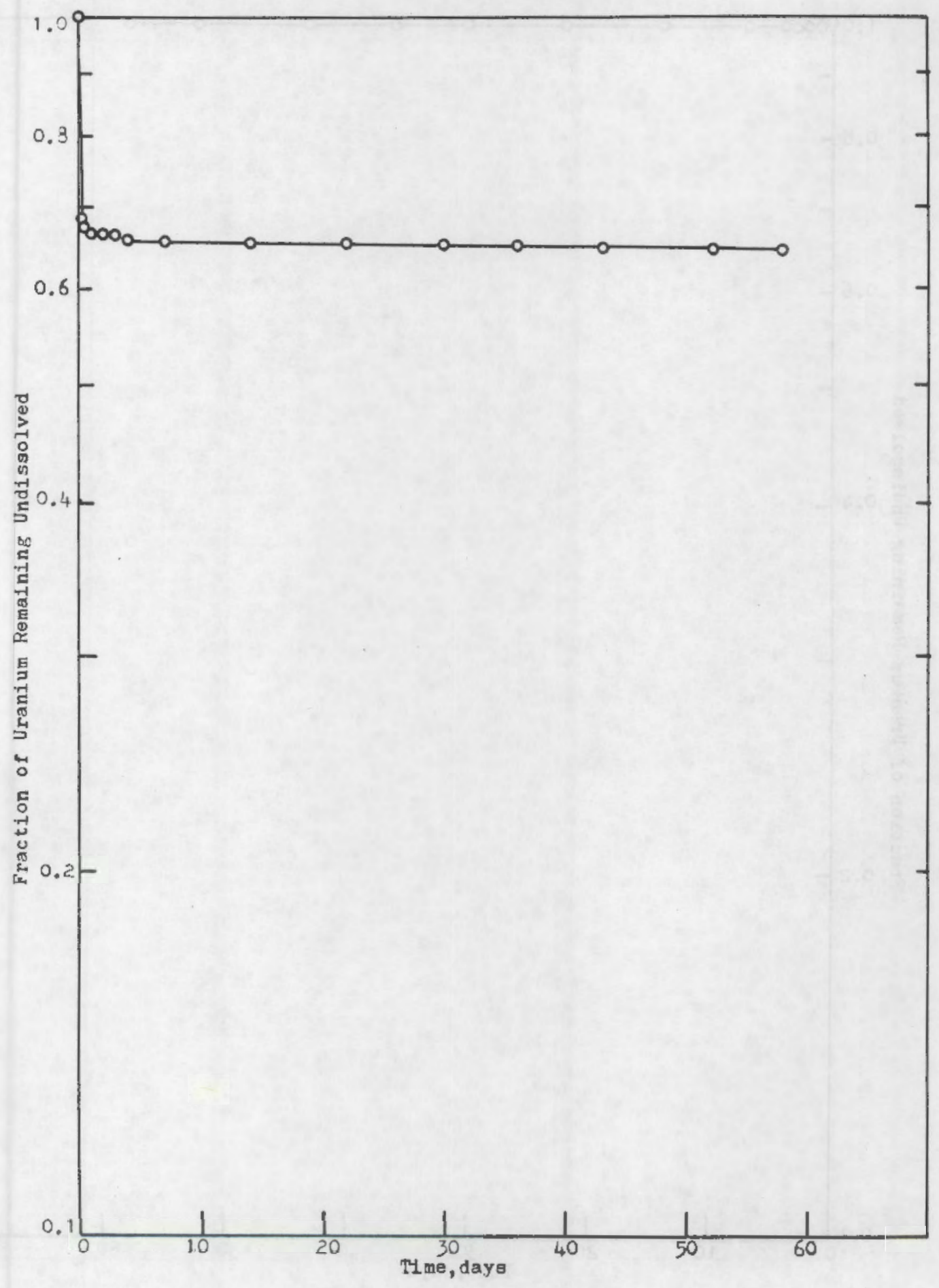


FIGURE 30. Dissolution of Dust Collected at General Electric's ADU Calciner Discharge, into Simulated Lung Fluid at $37^{\circ} \mathrm{C}$

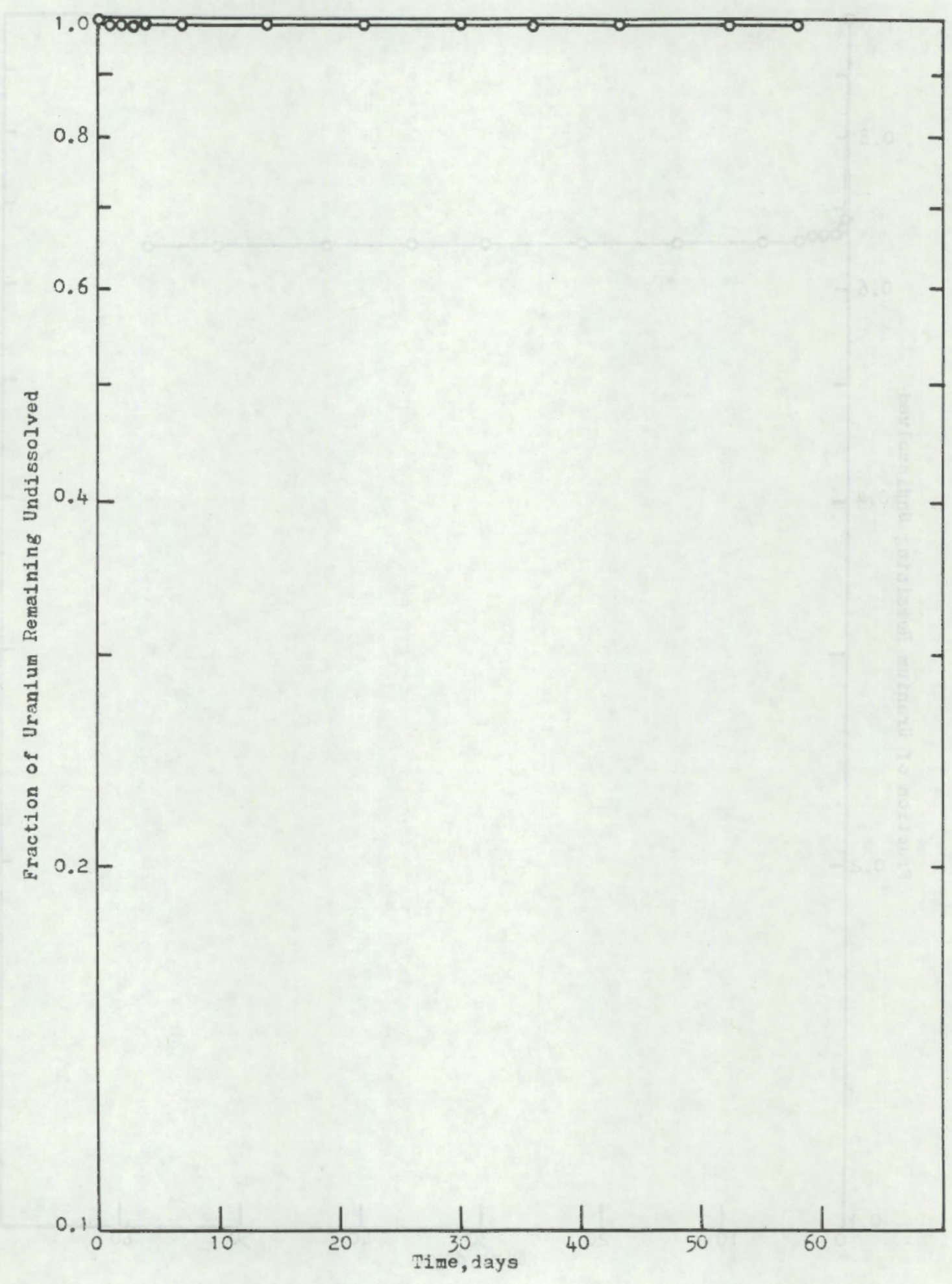


FIGURE 31. Dissolution of Dust Collected at General Electric's GECO Calciner Discharge, into Simulated Lung Fluid at $37^{\circ} \mathrm{C}$

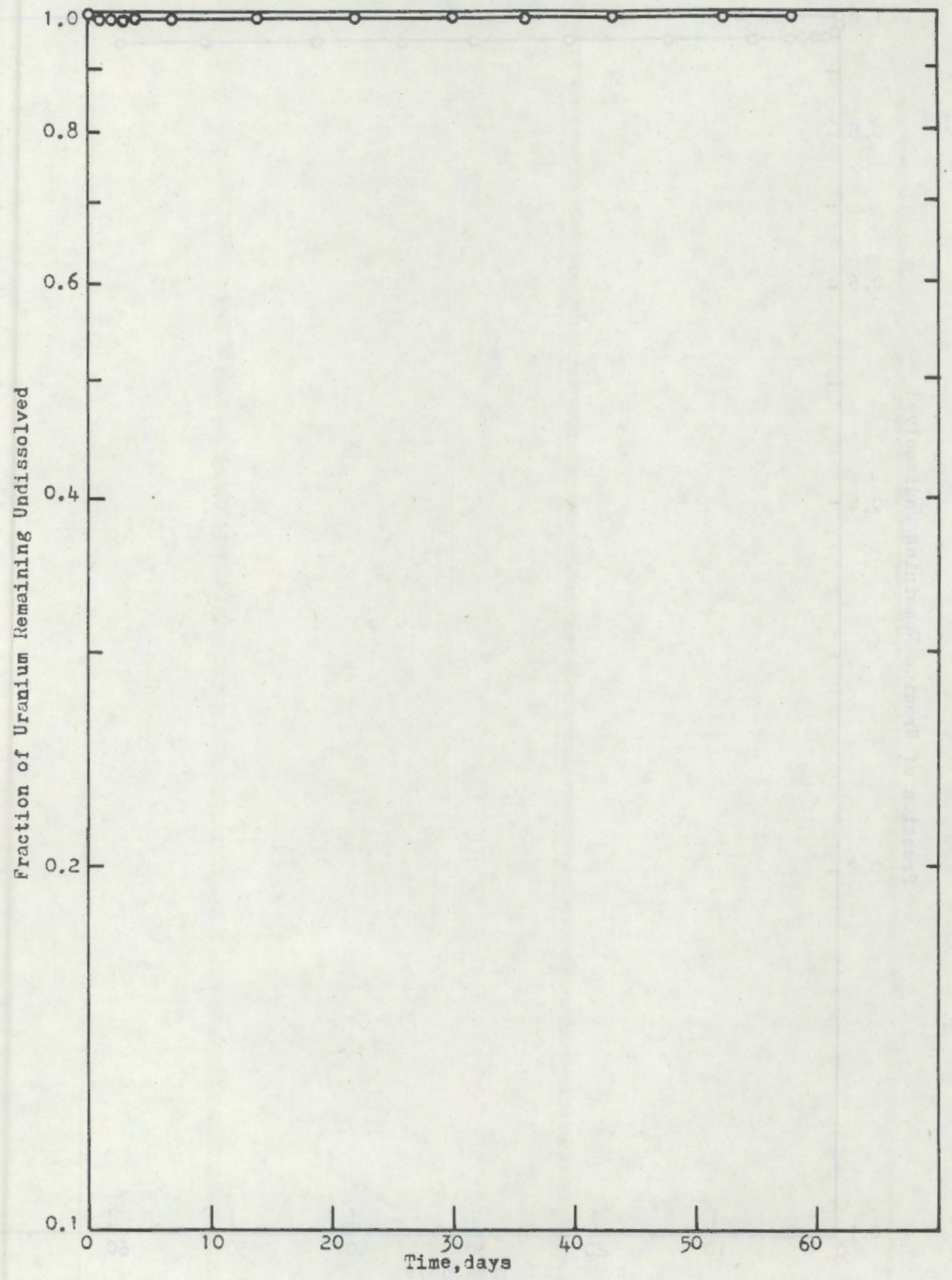


FIGURE 32. Dissolution of Dust Collected at General Electric's Pellet Press, into Simulated Lung Fluid at $37^{\circ} \mathrm{C}$

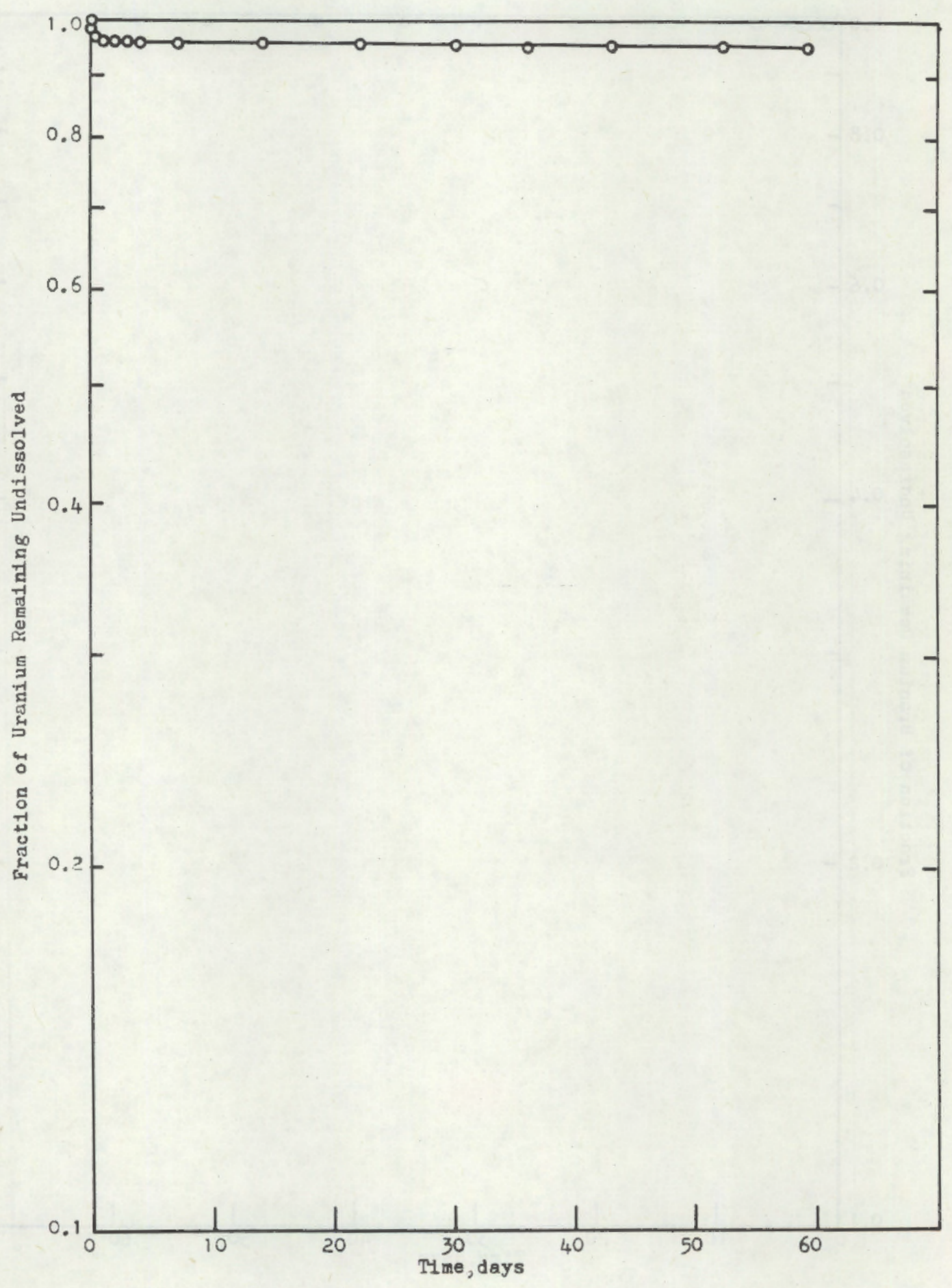


FIGURE 33. Dissolution of Dust Collected at General Electric's Pellet Grinder, into Simulated Lung Fluid at $37^{\circ} \mathrm{C}$

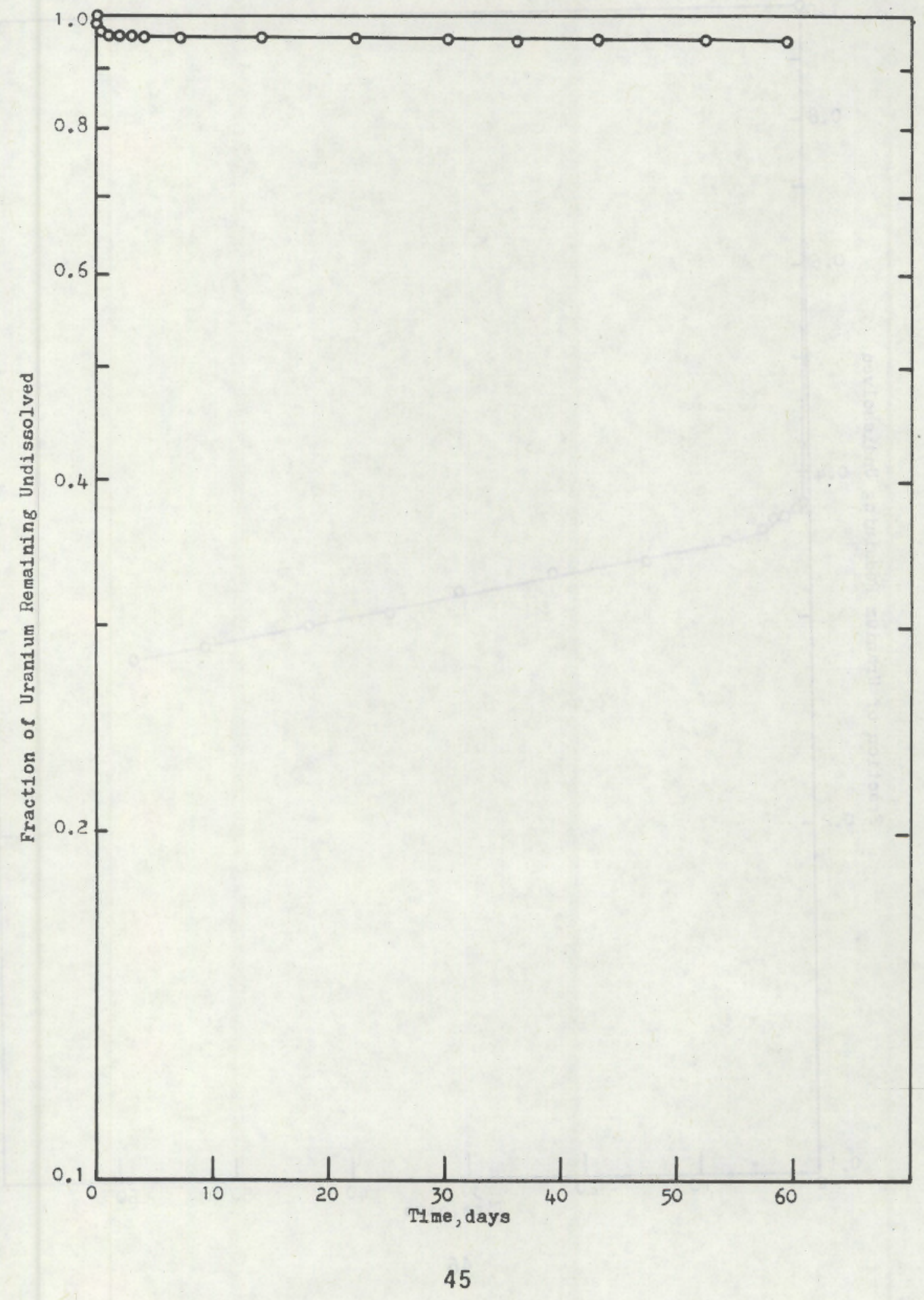


FIGURE 34. Dissolution of Dust Collected at General Electric's Chem Room Air Recirculation Intake, ADU End, into Simulated Lung Fluid at $37^{\circ} \mathrm{C}$

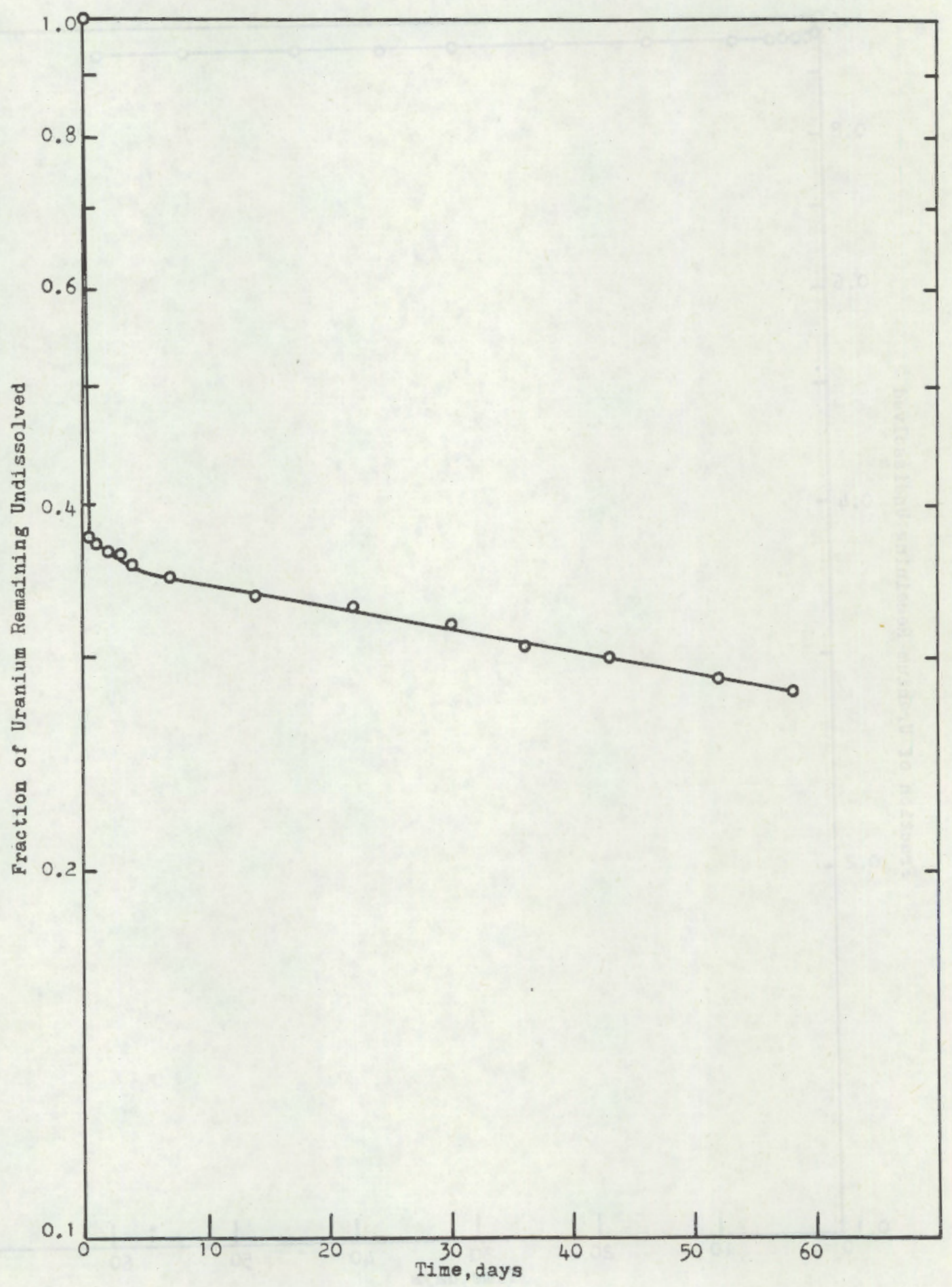


FIGURE 35. Dissolution of Dust Collected at General Electric's Chem Room Air Recirculation Intake, Center, into Simulated Lung Fluid at $37^{\circ} \mathrm{C}$

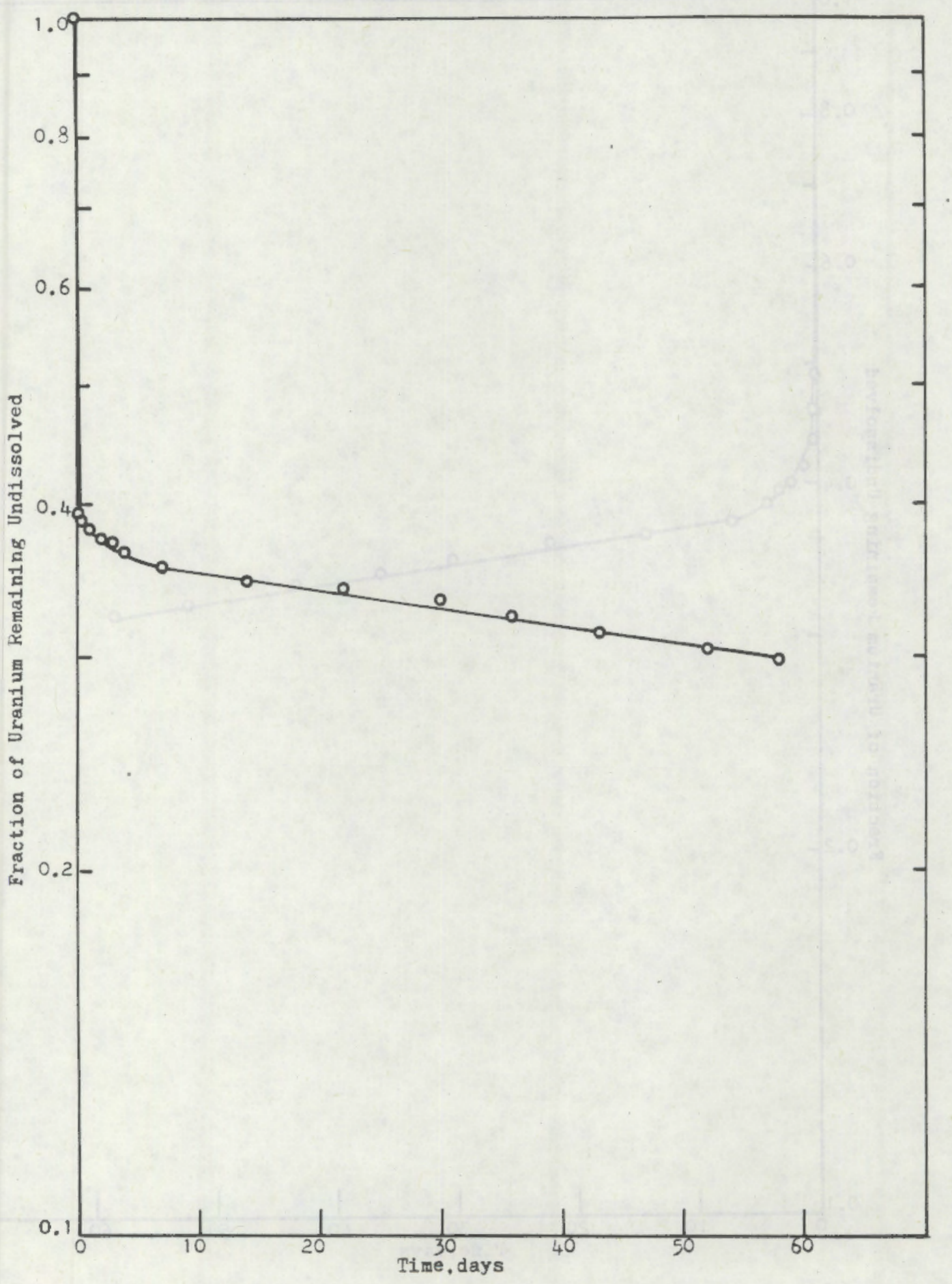


FIGURE 36. Dissolution of Dust Collected at General Electric's Chem Room Air Recirculation Intake, GECO End, into Simulated Lung Fluid at $37^{\circ} \mathrm{C}$

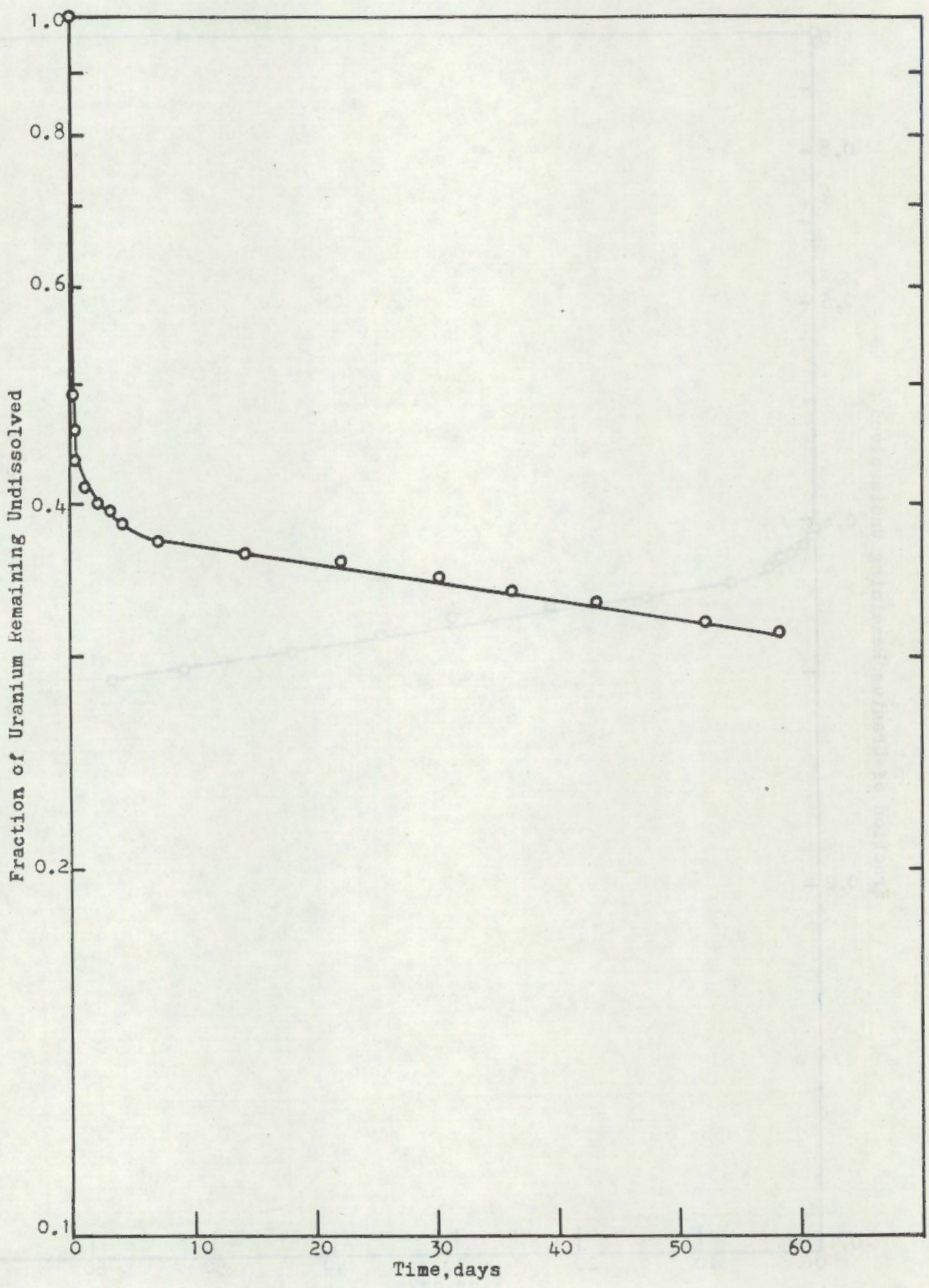


FIGURE 37. Optical Obsorption Spectrum of $1.78 \mathrm{~g} / \ell$ Uranium Solution in Simulated Lung Fluid

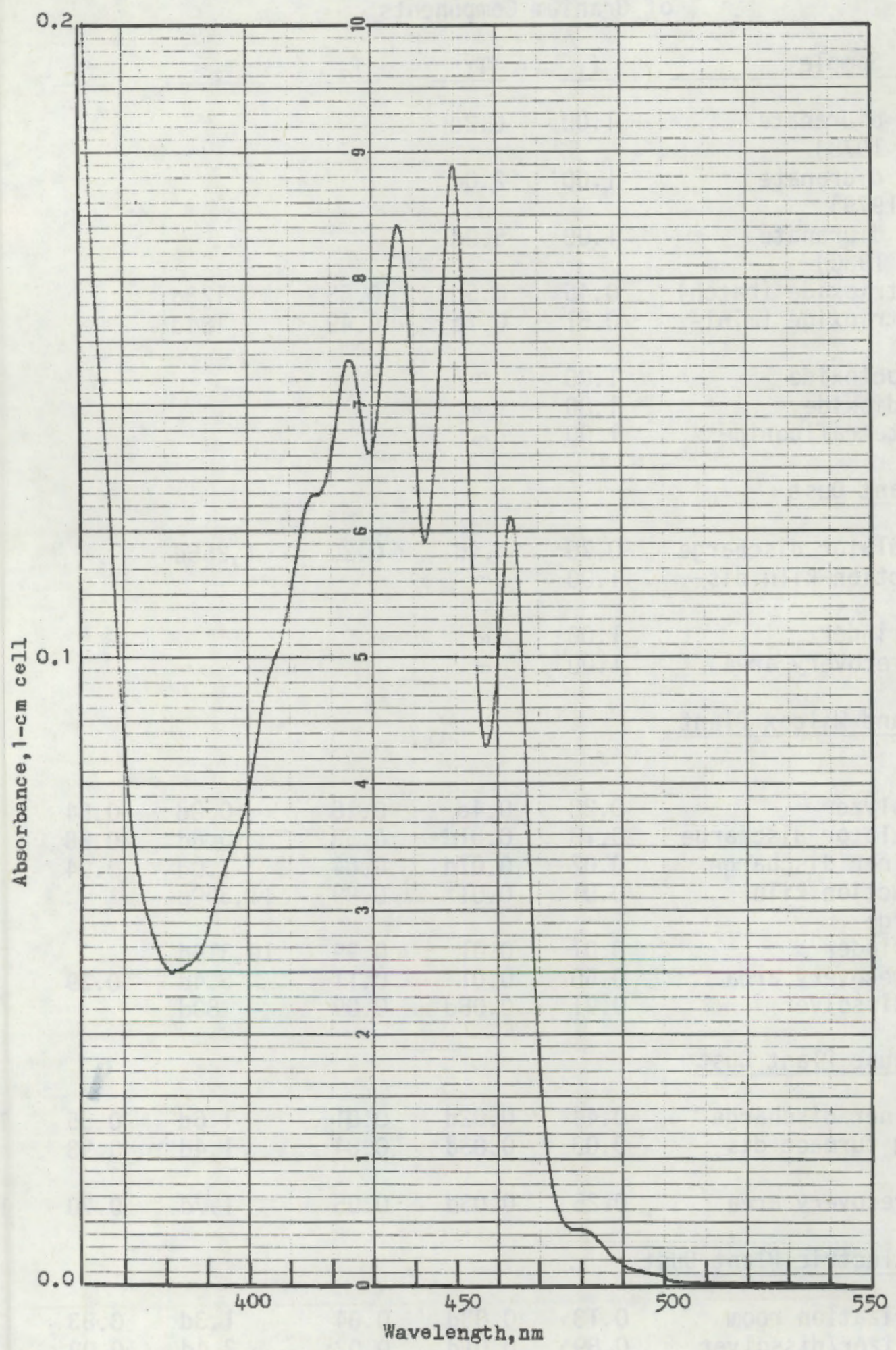


Sufficient terms were included to fit the data to the precision of the measurements. The results are tabulated in Table 4.

TABLE 4. Weight Fractions and Dissolution Half-times of Uranium Components

\begin{tabular}{|c|c|c|c|c|}
\hline Sample & $\mathrm{f}_{1}$ & $\mathrm{~T}_{1}$ & $f_{2}$ & $\mathrm{~T}_{2}$ \\
\hline $\begin{array}{l}\text { Ammonium diuranate } \\
\text { (Apri1 1978) }\end{array}$ & 1.00 & $0.2 \mathrm{~d}$ & & \\
\hline $\begin{array}{l}\text { Ammonium diuranate } \\
\text { (July 1979) }\end{array}$ & 1.00 & $2.0 \mathrm{~d}$ & & \\
\hline $\begin{array}{l}\text { Ammonium diuranate } \\
\text { (March 1980) }\end{array}$ & 1.00 & $5.0 \mathrm{~d}$ & & \\
\hline Uranium trioxide (batch) & 0.45 & $0.5 d$ & 0.55 & $123 d$ \\
\hline $\begin{array}{l}\text { Uranium trioxide (mini- } \\
\text { batch) }\end{array}$ & 0.51 & $0.7 \mathrm{~d}$ & 0.49 & 184d \\
\hline Uranium octoxide & 1.00 & $\infty$ & & \\
\hline Uranium dioxide & $\begin{array}{l}1.00 \\
.00\end{array}$ & $\begin{array}{l}\infty \\
\infty\end{array}$ & & \\
\hline Uranium tetrafluoride & & & & \\
\hline
\end{tabular}

Exxon Plant Dust

$\begin{array}{lllll}\text { AOU granulator discharge } & 0.70 & 0.4 \mathrm{~d} & 0.30 & 1,256 \mathrm{~d} \\ \text { ADU reduction-kiln dis- } & 1.00 & \infty & & \\ \text { charge } & 1.00 & \infty & & \\ \text { Pellet grinder } & 1.00 & \infty & \end{array}$

Babcock and Wilcox Plant Oust

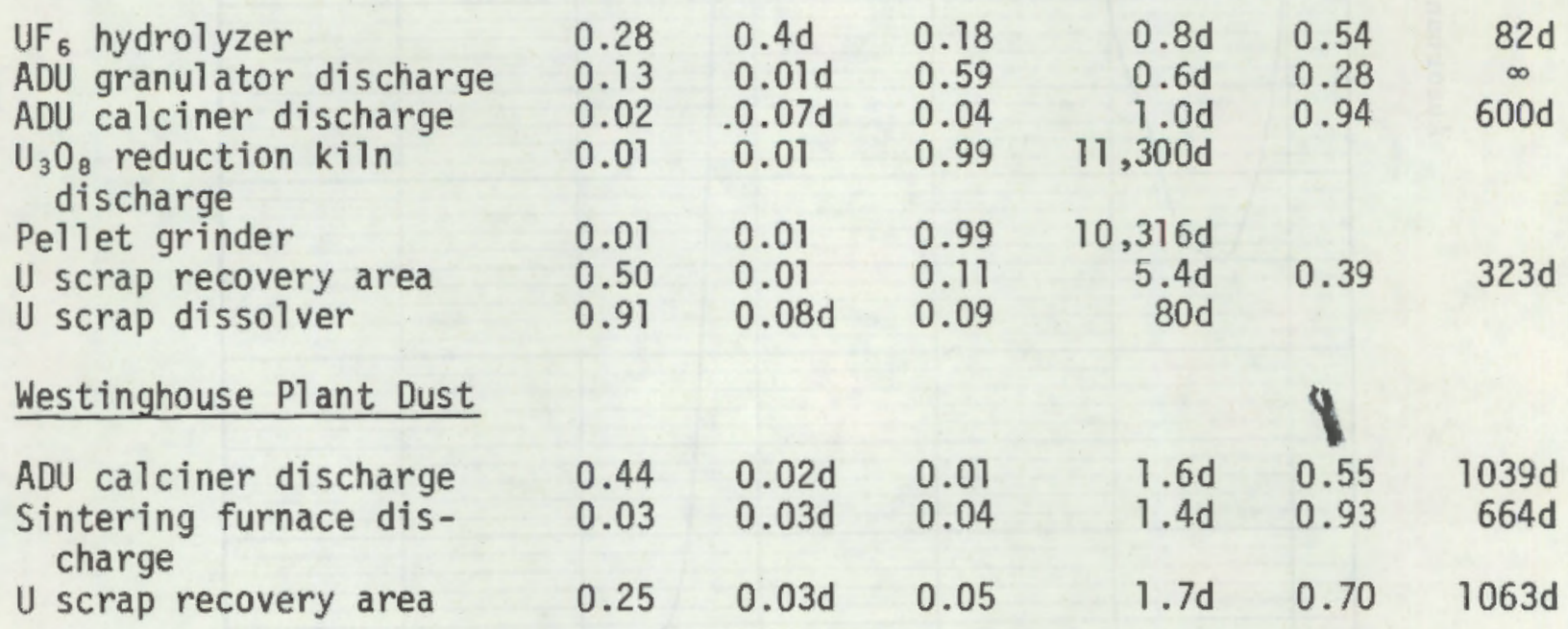

General Electric Plant Dust

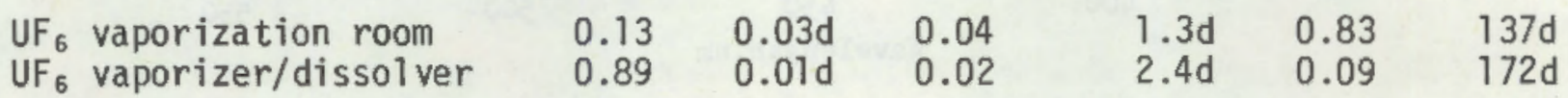


TABLE 4 (continued)

\begin{tabular}{|c|c|c|c|c|c|c|}
\hline Sample & $f_{1}$ & $\mathrm{~T}_{1}$ & $f_{2}$ & $\mathrm{~T}_{2}$ & $f_{3}$ & $\mathrm{~T}_{3}$ \\
\hline \multicolumn{7}{|l|}{$\frac{\text { Genera] Electric Plant }}{\text { Dust (continued) }}$} \\
\hline $\begin{array}{l}\text { ADU calciner feed } \\
\text { GECO calciner feed } \\
\text { ADU calciner discharge } \\
\text { GECO calciner discharge } \\
\text { Pellet press } \\
\text { Pellet grinder } \\
\text { Chem room air, ADU end } \\
\text { Chem room air, center } \\
\text { Chem room air, GECO end }\end{array}$ & $\begin{array}{l}0.63 \\
0.32 \\
0.01 \\
0.01 \\
0.04 \\
0.03 \\
0.54 \\
0.61 \\
0.62\end{array}$ & $\begin{array}{l}5.3 \mathrm{~d} \\
D .02 \mathrm{~d} \\
0.01 \mathrm{~d} \\
0.01 \mathrm{~d} \\
0.01 \mathrm{~d} \\
0.01 \mathrm{~d} \\
0.04 \mathrm{~d} \\
0.02 \mathrm{~d} \\
0.02 \mathrm{~d}\end{array}$ & $\begin{array}{l}0.37 \\
0.02 \\
0.99 \\
0.99 \\
0.96 \\
0.97 \\
0.07 \\
0.03 \\
0.02\end{array}$ & $\begin{array}{c}\text { T.4d } \\
\infty \\
\infty \\
\infty \\
\infty \\
0.92 \mathrm{~d} \\
1.8 \mathrm{~d} \\
1.9 \mathrm{~d}\end{array}$ & $\begin{array}{l}0.39 \\
0.37 \\
0.36\end{array}$ & $\begin{array}{l}189 \mathrm{~d} \\
196 \mathrm{~d} \\
167 \mathrm{~d}\end{array}$ \\
\hline
\end{tabular}

\section{SOLUBILITY CLASSIFICATIONS OF SAMPLES}

On the basis of the dissolution half-times of the samples listed in Table 4, their dissolution rates were classified in terms of the ICRP Task Group Lung Model as shown in Table 5.

\section{TABLE 5. Dissolution-rate Classifications of Samples} in Terms of the ICRP Task Group Lung Model

\section{Sample}

Ammonium diuranate

Uranium trioxide

Uranium octoxide

Uranium dioxide

Uranium tetrafluoride

Exxon Plant Dust

ADU granulator discharge

ADU reduction kiln discharge

Pellet grinder

U scrap recovery

Babcock and Wilcox Plant Dust

$U_{5}$ hydrolyzer

ADU granulator discharge

ADU calciner discharge

$\mathrm{U}_{3} \mathrm{O}_{8}$ reduction $k i l n$ discharge

Pellet grinder

U scrap recovery area

U scrap dissolver

\section{Classification}

D

$48 \%$ D, $52 \% Y$

Y

Y

Y

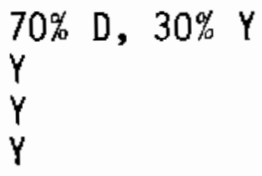

$46 \% \mathrm{D}, 54 \% \mathrm{~W}$

$72 \% \mathrm{D}, 28 \%$ Y

$6 \% \mathrm{D}, 94 \% \mathrm{Y}$

$1 \% \mathrm{D}, 99 \%$ Y

$1 \% D, 99 \% Y$

$67 \%$ D, 39\% Y

$97 \%$ D, $9 \% \mathrm{~W}$ 
TABLE 5 (continued)

Sample

ADU calciner feed

Sintering furnace discharge

U scrap recovery area

General Electric Plant Dust

$\mathrm{UF}_{6}$ vaporizer

$\mathrm{UF}_{6}$ vaporizer/dissolver

ADU calciner feed

GECO calciner feed

ADU calciner discharge

GECO calciner discharge

Pellet press

Pellet grinder

Chem room air, ADU end

Chem room air, center

Chem room air, GECO end
Classification

$45 \%$ D, $55 \%$ Y

$7 \% \mathrm{D}, 93 \% \mathrm{Y}$

$30 \% \mathrm{D}, 70 \% \mathrm{Y}$

\section{DISCUSSION}

Understanding of the dissolution behavior of even pure uranium compounds requires considerable information on their reactions with the components of either simulated or actual lung fluid. Only a portion of this information could be developed within the scope of the present work. The optical absorption spectrum of the solutions surrounding the dust samples provided an important clue concerning the dissolution mechanism. As stated previously, this spectrum, shown in Figure 37 , coincides with that for the $\left[\mathrm{UO}_{2}\left(\mathrm{CO}_{3}\right)_{3}\right]^{4-}$ anion. Thus, reasonable mechanisms for the dissolution of ammonium diuranate and uranium trioxide in SLF are:

$\left(\mathrm{NH}_{4}\right)_{2} \mathrm{U}_{2} \mathrm{O}_{7}$ (s) $+6 \mathrm{HCO}_{3}$ - (aq.) $\longrightarrow 2\left[\mathrm{UO}_{2}\left(\mathrm{CO}_{3}\right)_{3}\right]^{4-}$ (aq.) $+2 \mathrm{NH}_{4}+$ (aq.) $+\mathrm{H}_{2} \mathrm{O}$

$\mathrm{UO}_{3}(\mathrm{~s})+3 \mathrm{HCO}_{3}^{-}$(aq.) $\longrightarrow\left[\mathrm{UO}_{2}\left(\mathrm{CO}_{3}\right)_{3}\right]^{4^{-}}$(aq.) $+\mathrm{H}^{+}$(aq.) $+\mathrm{H}_{2} \mathrm{O}$

The non-exponential decrease in the fraction of $\mathrm{UO}_{3}$ found remaining undissolved in SL.F may be due to one or more reasons. It has been pointed out that $\mathrm{UO}_{3}$ is not a stable solid phase in the presence of large concentrations of cations. ${ }^{15}$ This instability has been attributed to the greater insolubi1ity of uranates as compared with $\mathrm{UO}_{3}$, e.g.,

$$
2 \mathrm{UO}_{3}(\mathrm{~s})+4 \mathrm{Na}^{+} \text {(aq.) }+\mathrm{H}_{2} \mathrm{O} \longrightarrow \mathrm{Na}_{4} \mathrm{U}_{2} \mathrm{O}_{7}(\mathrm{~s})+4 \mathrm{H}^{+} \text {(aq.) }
$$


Alternatively, the surface of $\mathrm{UO}_{3}$ crystals may be such that the calcium ion in SLF may react there to form insoluble calcium uranyl carbonate ${ }^{16}, \mathrm{e.g.}$,

$$
\begin{gathered}
\mathrm{UO}_{3}(\mathrm{~s})+3 \mathrm{HCO}_{3}^{-}(\mathrm{aq} .) \longrightarrow \\
\left.\qquad \mathrm{UO}_{2}\left(\mathrm{Ca}_{3}\right)_{3}\right]^{4-}(\mathrm{aq} .) \\
\mathrm{Ca}_{2} \mathrm{UO}_{2}\left(\mathrm{CO}_{3}\right)_{3}(\mathrm{~s})
\end{gathered}
$$

The kinetics of the competing dissolution and reprecipitation processes may be such that considerable $\mathrm{UO}_{3}$ may dissolve before the remaining crystals are completely coated with $\mathrm{Ca}_{2} \mathrm{UO}_{2}\left(\mathrm{CO}_{3}\right)_{3}$.

Dissolution of tetravalent uranium compounds requires the presence of oxygen as an oxidizing agent ${ }^{17}$, e.g.,

$$
2 \mathrm{UO}_{2}+6 \mathrm{HCO}_{3}^{-}+\mathrm{O}_{2} \longrightarrow 2\left[\mathrm{UO}_{2}\left(\mathrm{CO}_{3}\right)_{3}\right]^{4^{-}}+2 \mathrm{H}_{2} \mathrm{O}+2 \mathrm{H}^{+}
$$

Although the tetravalent compounds were exposed to air-saturated solutions of SLF throughout the dissolution process, it seems possible that the oxidation of uranium surfaces at such an oxygen tension may be quite slow and account for the long dissolution half-times of these compounds. Such conditions, of course, would also prevail in the lung.

COMPARISON OF CLASSIFICATIONS WITH LITERATURE VALUES

There is general agreement that uranium hexafluoride, $U F_{6}$, uranyl nitrate, $\mathrm{UO}_{2}\left(\mathrm{NO}_{3}\right)_{2}$, and uranyl fluoride, $\mathrm{UO}_{2} \mathrm{~F}_{2}$, are Class $\mathrm{D}$ compounds ${ }^{18-20}$. Thus, pure samples of these compounds, which are expected to be airborne in LWR-fuel plants, were not investigated in this study.

Ammonium diuranate has been assigned by others to Class $W^{19,20}$, but the evidence for this work is that the classification may well depend on the age of the product and its thermal history. The sample used in this study continued to demonstrate Class $D$ behavior over a two-year period, but it was obviously approaching the status of a Class $W$ compound. Ammonium diuranate is known to undergo rapid decomposition at $300^{\circ} \mathrm{C}$ to form uranium trioxide and ammonia. ${ }^{21}$ It seems possible that a similar slow reaction could occur at the surface of ammonium diuranate at room temperature to convert it from a Class D compound to a $C l a s s ~ W$ one. A more rapid transformation of this could could occur in ADU driers and granulators. 
Pure uranium trioxide was assigned to a mixed class $48 \% \mathrm{D}, 52 \% \mathrm{Y}$ in this work. In other reports, this compound has been assigned to the $W$ class $^{19,20 \text {, }}$ 22,23 . Possible reasons for the mixed classification of this compound have been discussed under DISSOLUTION MECHANISM.

Both uranium dioxide and uranium octoxide were assigned Class $Y$ from this work, and similar classifications were made on the basis of two other studies reported in the 1 iterature ${ }^{19,24}$. $U_{3} \mathrm{O}_{8}$ was assigned to Class $W$ in another report, but the basis for this classification is unclear ${ }^{20}$.

Uranium tetrafluoride was assigned Class $Y$ from this work, and received the same classification by this author in an examination of the dissolution behavior of two commercial samples of $U F_{4}$. This compound has been assigned to $C l a s s ~ W$ in two reports ${ }^{19,20}$, but the disagreement may well be due to differences in the thermal histories of the samples.

COMPARISON OF PLANT-SAMPLE CLASSIFICATIONS WITH EXPECTATIONS

At the front end of LWR-fuel plants, one would expect to incur airborne $\mathrm{UF}_{6}$ and $\mathrm{UO}_{2} \mathrm{~F}_{2}$. This expectation was supported by the high percentage of Class $D$ uranium in the sample collected at the $U_{6}$ hydrolyzer of the Babcock and Wilcox plant and one of two sampling locations near the UF $_{6}$ hydrolyzer at the General Electric plant. The large amount of Class $Y$ uranium found at the other sampling location may indicate that it receives airborne uranium from other parts of the General Electric plant.

The main airborne products expected at an ADU granulator or in the calciner feed are ammonium diuranate and uranium trioxide. The dissolution behavior of dust at such locations in all four plants was in agreement with this expectation. The products ranged from 45 to $72 \% \mathrm{D}$ with the remainders being Class $Y$. This corresponds to the classification of ammonium diuranate that has been partially converted to uranium trioxide during the drying process. The calciner feed in a dry process stream, such as that at the General Electric plant, is expected to contain $\mathrm{UO}_{2} \mathrm{~F}_{2}, \mathrm{U}_{3} \mathrm{O}_{8}, \mathrm{UF}_{4}$, and $\mathrm{UO}_{2}$. Since all of these except $\mathrm{UO}_{2} \mathrm{~F}_{2}$ were found to be class $Y$ compounds in this study, a sample from this location would be expected to have both $D$ and $Y$ components, with the latter predominating. This was, in fact, the situation found. 
At the discharge end of a calciner, the expected product is $U_{3} 0_{8}, a$ Class $Y$ compound. This was confirmed by studies on the dust samples from this location at the Babcock and Wilcox and General Electric plants. The 1-6\% of Class 0 material probably represents incomplete conversion of $\left(\mathrm{NH}_{4}\right)_{2} \mathrm{U}_{2} \mathrm{O}_{7}$ to $\mathrm{U}_{3} \mathrm{O}_{8}$.

At the discharge end of the reduction kiln and at the fuel-pellet press, the expected product is $\mathrm{UO}_{2}$, a Class $Y$ compound. This was confirmed by the dissolution behavior of the dust samples from such locations at the Exxon, Babcock and Wilcox, and General Electric plants.

Dust from $\mathrm{UO}_{2}$ that has passed through a sintering furnace is expected to remain $\mathrm{UO}_{2}$ but to be more resistant to dissolution. This was confirmed by the dissolution behavior of the dust samples from the sintering furnaces and peilet grinders of the plants.

At scrap recovery areas, uranium materials are heated in air to reoxidize $\mathrm{UO}_{2}$ to $\mathrm{U}_{3} \mathrm{O}_{8}$, and then the $\mathrm{U}_{3} \mathrm{O}_{8}$ is dissolved in nitric acid for reintroduction at the front end of the process line. Both Class $\mathrm{Y} \mathrm{U}_{3} \mathrm{O}_{8}$ and Class $\mathrm{D} \mathrm{UO}_{2}\left(\mathrm{NO}_{3}\right)_{2}$ are thus expected in this area, and the composition of dust in an air sample would depend on the exact location of the sampling system. This was confirmed in samples from three of the plants. The sample from the Exxon plant was $100 \% \mathrm{Y}$ indicating only $\mathrm{U}_{3} 0_{9}$ was present, and this was confirmed by crystallographic analysis. The sample from Westinghouse plant was $30 \% \mathrm{D}, 70 \% \mathrm{Y}$, suggesting the presence of both $\mathrm{U}_{3} \mathrm{O}_{8}$ and $\mathrm{UO}_{2}\left(\mathrm{NO}_{3}\right)_{2}$. A similar result, $61 \% \mathrm{D}, 39 \% \mathrm{Y}$, was obtained from the sample collected in the analogous location of the Babcock and Wilcox plant. Closer to the actual scrap dissolver at this plant, airborne dust had the classification 91\% D, $9 \% \mathrm{~W}$, suggesting almost pure $\mathrm{UO}_{2}\left(\mathrm{NO}_{3}\right)_{2}$.

Samples collected at the air-recirculation intakes for the "Chem Room" in the General Electric plant provide an interesting insight into the composition of airborne dust from a major portion of the overall process; i.e., from hydrolys is of the $\mathrm{UF}_{6}$ to formation of granulated $\mathrm{UO}_{2}$ ready for the pellet presses. Since this plant runs the ADU process and its dry process in parallel lines on different sides of the room, it was also of interest to compare the overall classifications of dust samples in a direction at right 
angles to the process streams. The results showed that the dissolution-rate classification of dust at these room-air intakes is independent of latera? position across the room and, perhaps coincidentally, is that of dust from the feed to the ADU calciner, i.e., $63 \% \mathrm{D}, 37 \% \mathrm{Y}$. 


\section{REFERENCES}

1. Task Group on Lung Dynamics for Committee II of the International Commission on Radiological Protection, "Deposition and Retention Models for Interna] Dosimetry of the Human Respiratory Tract." Health Phys. 12: 173-206 (7966).

2. L. M. Steckel and C. M. West, Characterization of $Y-12$ Uranium Process Materials Correlated with In Vivo Experience. Y-1544A, Union Carbide Corporation, Oak Ridge Y-î Plant, Oak Ridge, TN 37831 (1966).

3. N. Cooke and F. B. Holt, "The Solubitity of Some Uranium Compounds in Simulated Lung Fluid." Health Phys. 27:69-77 (1974).

4. P. E. Morrow, F. R. Gibb, and L. Johnson, "Clearance of Insoluble Dust from the Lower Respiratory Tract." Health Phys. 10:543-555 (1964).

5. P. E. Morrow, F. R. Gibb, H. Davis, and M. Fisher, "Dust Removat from the Lung Parenchyma: An Investigation of Clearance Stimulants." Tox. and Appl. Pharm. 12:372-396 (1968).

6. J. R. Houston, D. L. Strenge, and E. C. Watson, DACRIN - A Computer Program for Calculating Organ Dose from Acute or Chronic Radionuclide Inhalation. BNWL-8-389, Pacific Northwest Laboratory, Richtand, WA (1975).

7. K. Diem and C. Lentner, Ed., Documenta Geigy Scientific Tables, Seventh Edition, CIBA-GEIGY, Ltd., Basel, p. 523 (1970).

8. 0. R. Moss, "Simulants of Lung Interstitial Fluid." Health Phys. 36: $447-448(1979)$.

9. N. A. Dennis, Dissolution Rates of Yellowcake in Simulated Lung Fluids, M. S. Thesis, University of Pittsburgh, Pittsburgh, PA (1979).

10. D. R. Kalkwarf, Solubility Classification of Airborne Products from Uranium Ores and Tailings Piles. NUREG/CR-0530, PNL-2870, Pacific Northwest Laboratory, Richiland, WA (1979).*

11. W. J. Maeck, G. L. Boonan, I. C. Elliott, and J. E. Rein, "Spectrophotometric Extraction Methods Specific for Uranium." Ana1. Chem. 31: 11301134 (1959).

12. C. J. Rodden, Ed., Selected Measurement Methods for Pi utonium and Uran$i$ in in the Nuclear Fuel Cycle, Second Edition. TID-7092, Office of Information Services, U. S. Atomic Energy Commission (1972).

13. Arrerican Socjety of Testing and Materials, "Standard Test Methods for Microquantities of Uranium in Water by Fluorometry," Procedure 02907-75, 1979 Annual Book of ASTM Standards, Part 45, Nuclear Standards, PP. 783788, American Society for Testing and Materia1s, Philadelphia, PA (1979).

*Available for purchase from the NRC/GPO Sales Program, U.S. Nuclear Regulatory Comission, Washington, $D C$ 20555, and the National Technical Information Service, Springfield, VA 22161. 


\section{REFERENCES (continued)}

14. T. T. Mercer, "On the Role of Particle Size in the Dissolution of Lung Burdens." Hea1th Phys.- 13:1211-1221 (1967).

15. L. A. McClaine, E. P. Buliwinkel, and J. C. Huggins, "The Carbonate Chemistry of Uranium: Theory and Applications." Proc. Intern. Conf. on Peaceful Uses of Atomic Energy, Geneva 1955, 8: $\overline{26-37}(1 \overline{956})$.

16. H. Füredi-Milhofer, Z. Despotovic', L. Devide", and M. Wrischer, "Precipitation and Hydrolys is of Uranium (VI) in Aqueous Systems-VII, Study of the Precipitates Formed in the Systems Uranyl Nitrate-Sodium Carbonate-Alkaline Earth Chlorides." J. Inorg. Nucl. Chem. 34: 1961-1969 (1972).

17. J. H. Gittus, Uranium. Butterworths, Washington, p. 41-42 (1963).

18. J. Chalabreysse, "Etude et Résultats d' Examens Effectúes á la Suite d' une Inhalation de Composes dits Solubles d' Uranium Naturel." RadioProtection 5: 1-17 and 305-310 (1970).

19. N. Cooke and F. B. Holt, "The Solubility of Some Uranium Compounds in Simulated Lung Fluid." Health Phys. 27:69-77 (1974).

20. R. E. Alexander, Applications of Bioassay for Uranium. WASH-1251, Directorate of Regulatory Standards, U. S. Atomic Energy Conmission (1974).

21. W. D. Wilkinson, Uranium Metallurgy, Volume 1. Uranium Process Metal= lurgy. Interscience, New York, p. 25 (1962).

22. P. E. Morrow, F. R. Gibb, and H. D. Beiter, "Inhalation Studies of Uranium Trioxide." Health Phys. 23:273-280 (1972).

23. J. B. Hursh and N. L. Spoor, "Data on Man" in Uranium, Plutonium Transplutoni um Elements, Eds. H. C. Hodge, J. N. Stannard, and J. B. Hursh. Springer-Verlag, Berlin, pp. 197-239 (1973).

24. P. E. Morrow, F. R. Gibb, and L. J. Leach, "The Clearance of $\mathrm{UO}_{2}$ Dust from the Lungs Following Single and Multiple Inhalation Exposures." Hea 1th Phys. 12:1217-1223 (1966). 


\section{ACKNOWLEDGMENTS}

The author wishes to thank and acknowledge the assistance of the following people in obtaining the plant samples used in this study: Mr. Paul Estey, Exxon Nuclear Co., Richland, WA; Mr. Ronald D. Corridoni, Babcock and Wilcox, Nuclear Fuels Division, Apo110, PA; Dr. G. Edward Powers, General Electric Co., Nuclear Energy Products Division, Wilmington, $\mathrm{NC}$; and $\mathrm{Mr}$. Richard $\mathrm{K}$. Burklin, Westinghouse Electric Corporation, Nuclear Fuel Divisions, Columbia, SC. The author also gratefully acknowledges the assistance of other staff members at the Pacific Northwest Laboratory: Mr. Dean Robertson and $\mathrm{Mr}$. Harvey Tenny, for conducting the microprobe and X-ray crystallographic samples; Mr. James Merril for assisting in the parametric resolution of the dissolution data; and particularly Mr. Charles Veverka for technical assistance in all phases of the work. 
$\cdot$
$\ddots$
'. 


\section{DISTRIBUTION}

No. of

\section{Copies}

OFFSI TE

A. A. Churm

DOE Patent Division 9800 S. Cass Avenue Argonne, IL 60439

265

65

No. of

Copies

\section{ONSITE}

35

Pacific Northwest Laboratory

W. D. Fe] ix

D. R. Kalkwarf (25)

R. W. Perkins

L. C. Schwendiman

Technical Information (5)

Publishing Coordination
Division of Technical Information \& Document Control

7920 Norfolk Avenue

Bethesda, MD 20014

2 OOE Technical Information Center

Oak Ridge, TN 37830

25 Dr. Lewis Battist

U. S. Nuclear Regulatory Commission

office of Standards Development

Wasnington, D. C. 20555

Mr. Paul Estey

Exxon Nuclear Co.

2101 Horn Rapids Road

Richland, WA 99352

Mr. Ronald D. Corrjdonj

Babcock and Wilcox Co.

Nuclear Materials Division

609 N. Warren Avenue

Apol10, PA 15613

Dr. G. Edward Powers

General Electric Co.

Nuclear Energy Products

Division

P. 0. Box 780

Wilmington, NC 28401

Mr. Richard K. BurkTin

Westinghouse Electric Corp.

Nuclear Fuels Division

Drawer R

Columbia, SC 29205 
" 


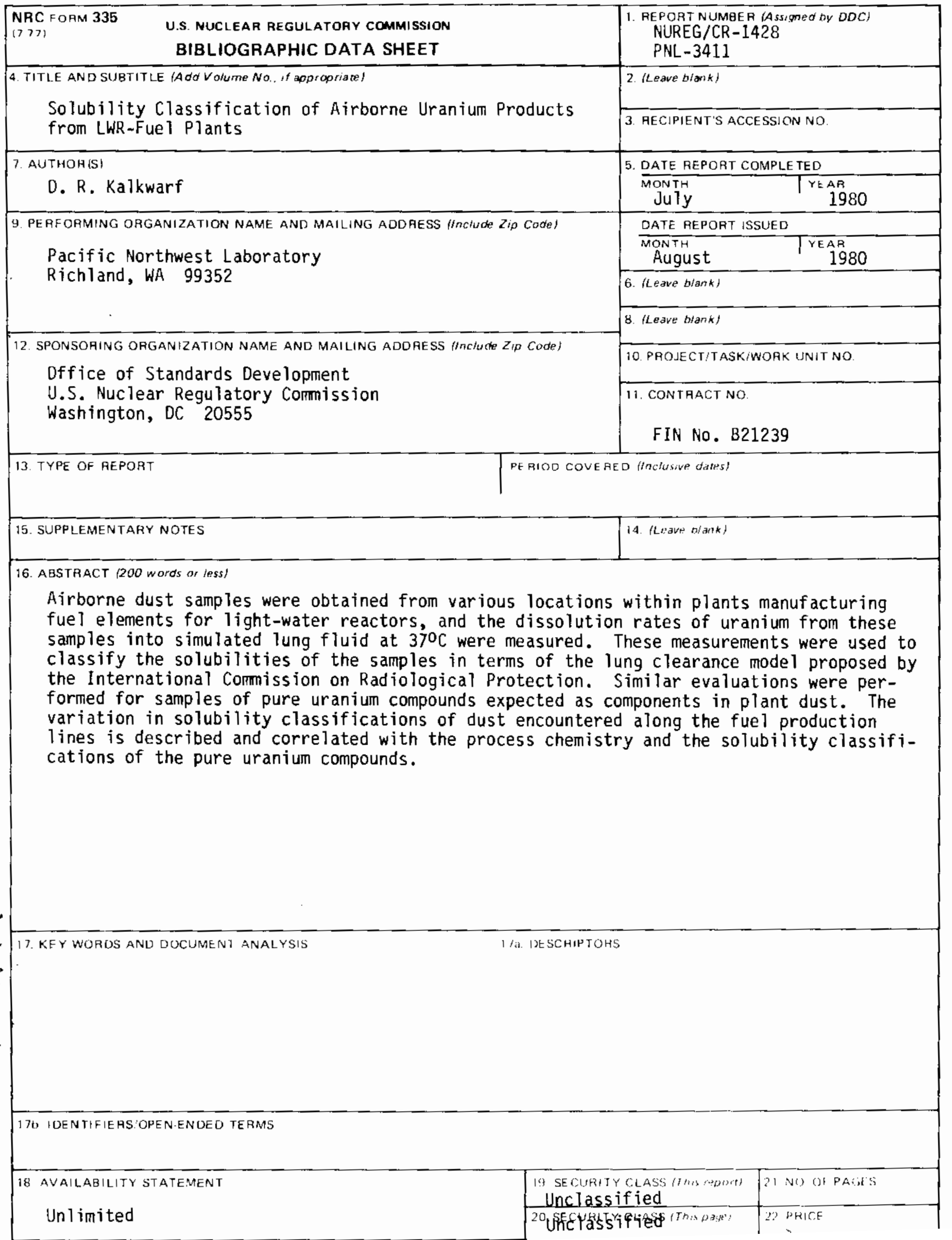


4
$\cdot$
$\cdot$
4
4 